Historic, Archive Document

Do not assume content reflects current scientific knowledge, policies, or practices. 



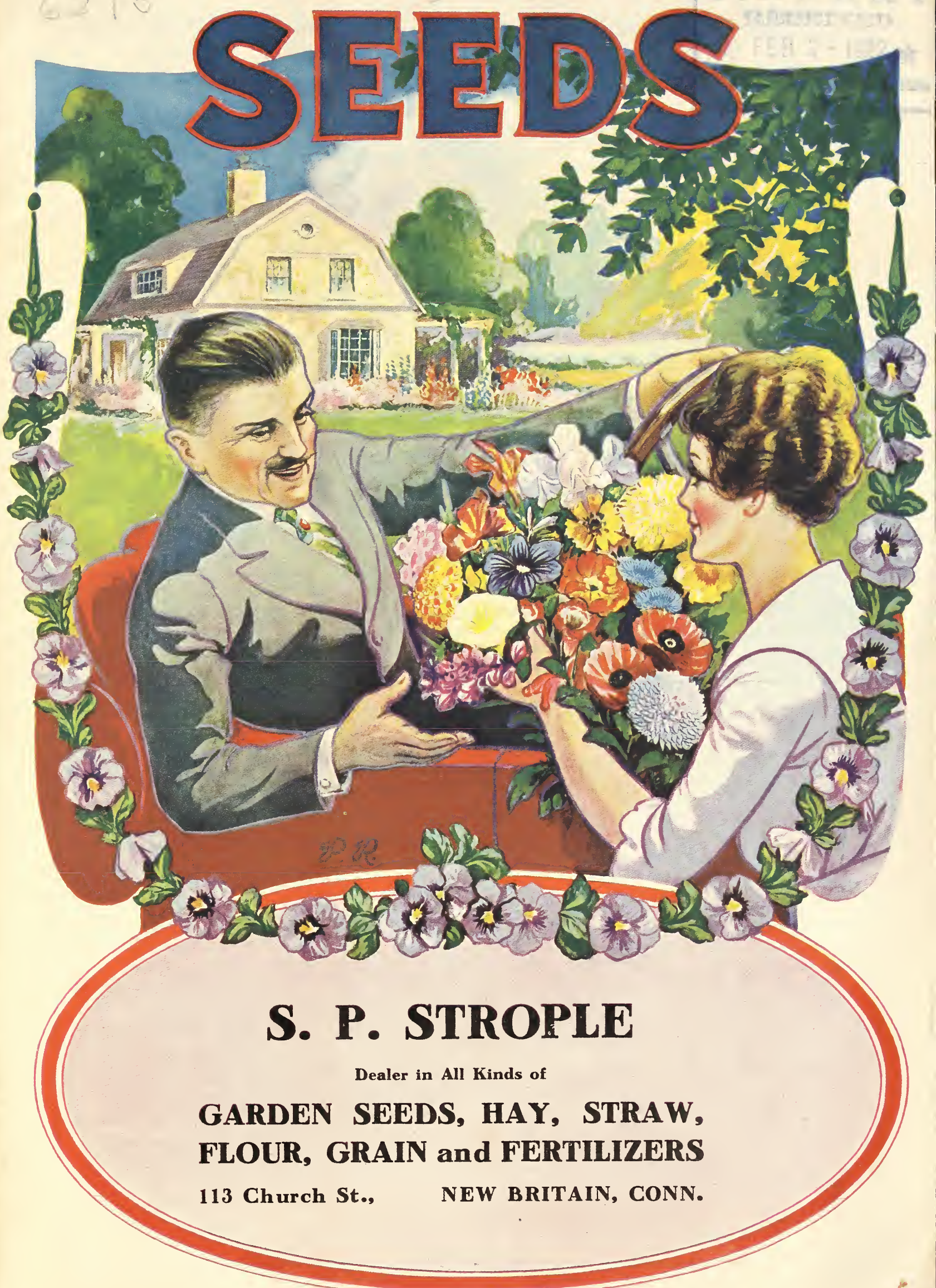




\section{SEEDS--Buy Them at Home}

It is not necessary for you to send away for your garden seeds when you can buy choice, Northern grown, bulk garden seeds at home.

We carry a complete line of bulk garden seeds and are in a position to take the best care of your seed wants. Our seeds are all carefully tested, new crop seeds, not the kind put up in fancy packets and sold on commission, which you may have purchased in the past and which may not have given satisfaction.

When you buy from us you see what you are getting, save the trouble of sending away to some mail order house, and you do not have to wait for your seeds to come by parcelpost or express and possibly be delayed or lost. You also save the cost of transportation.

Come in and see how much fresh bulk seed you get for your money.

More seed and better seed for less money.

\section{BUY BULK SEEDS FOR SUCCESS}

\section{Cut the Cost of Living with a Vegetable Garden}

I IT IS surprising how small a piece of ground is needed to supply a family of average size with fresh vegetables through the whole season. A piece of ground, say, thirty feet by forty feet, will do it. In these days of high prices there are many sorts of vegetables that it more than pays to grow at home. In comparison with the ridiculously small cost, the return surely does warrant the effort.

U How can it be done? The preparation of the plat is the first consideration. The ground must be well worked up, all sticks, stones and large lumps removed, and in most instances it will be necessary to turn under a goodly amount of stable manure or humus. Commercial fertilizer may also be applied sparingly at time of planting in the rows, or beside the rows of plants later on.

I PICK a well drained spot in the yard where the sun shines all day long and there are no shade trees, for vegetables as well as flowers need plenty of sunshine plus lots of cultivation and then some more cultivation.

I NEXT, the seed. Be sure of your seed, as it is most discouraging to find after you have planted and worked all summer that you have nothing worth while to show for your pains.

- I Panting Lettuce, Radish, Carrots, Beets, Early Onions and Turnips requires very little room and can be grown between those sorts that require more space. Put Corn and tall kinds where they will not shade in any way the more dwarf kinds.

U. How shall I plant or lay out the bed? Why not try it this way: Half a pint of Wax Beans planted, say, in two rows, followed by half a pint of green podded kinds. One row of Early Cabbage (use plants). One or two quarts of Peas-early and late in two rows. One row of Early Beets. Follow Peas and Beets with a planting of Late Cabbage (use plants of your own growing). Half a row of Radish, Early Round. Half a row of Long White or Red. One-half row Lettuce, curled leaf, half row Head Lettuce. One row of Onion Sets. Follow Onion, Radish and Lettuce with Egg Plant, Pepper, Turnip and Rutabaga. One row of Cucumber, Early and Late. One row of Tomato. Four rows of Sweet Corn, early and late, Squash, Pumpkins, etc.

I MANY other sorts may be added to this list which are well worth the time and effort of producing. 


\section{How to Grow Bumper Crops of Clover Alfalfa, Peas Beans, and Legumes}

Until recent years the value of bacteria to plant-growth was almost unknown. When a leguminous crop failed to grow, or made cnly a weak stand, the farmer generally blamed the weather, the condition of the soil, or the seed. How could he know about bacteria which were invisible to the naked eye, and how could he learn that they had to be present before a good crop could be had? Now, science has taught that inoculation is most essential, and that crops which formerly failed may be grown with great success.

Inoculation is only certain to be successful ( I) when the seed-bed has been properly prepared; (2) when the soil is sweet; (3) when you use good seeds; (4) when the inoculant is fresh and virile. The first three conditions must be brought about by the grower; the last one can be guaranteed by using Farmogerm.

Inoculated cover crops add as much nitrogen to the soil as could be obtained from tons of nitrate of soda, yet the expense is trifling when compared to the cost of the chemical. Many crops practically refuse to grow unless the seed has been treated. Alfalfa is most particular in this respect, but the clovers, soy beans, and cowpeas are almost as dependent. The amount of hay grown upon an acre has been increased from less than a ton to four tons by inoculation alone. Add to this the value of the nitrogen added to the soil and you gain an idea of the profit Farmogerm produces. We recommend its use on every pound of seed you sow.

\section{Treat These Seeds With Farmogerm}

All of these seeds make a stronger growth and will add more nitrogen to the soil if they are inoculated with Farmogerm. Their cultures are all different; in ordering be sure to state what crop you wish to inoculate.

$\begin{array}{ll}\text { Alfalfa, or Lucerne } & \text { Jerusalem Peas } \\ \text { Red Clover } & \text { Cowpeas } \\ \text { Mammoth Clover } & \text { Soy Beans } \\ \text { Crimson Clover } & \text { Velvet Beans } \\ \text { Alsike Clover } & \text { Sword or Jack Beans } \\ \text { White Clover } & \text { Garden Beans } \\ \text { Burr Clover } & \text { Lima Beans } \\ \text { Sweet Clover } & \text { Moth Beans } \\ \text { Yellow Clover } & \text { Horse Beans } \\ \text { Yellow Trefoil } & \text { Vetch (Spring and } \\ \text { Berseem Clover } & \text { Winter) } \\ \text { Japan Clover } & \text { Peanuts } \\ \text { Chick Pea, or } & \text { Lupines } \\ \quad \text { Garbanza } & \text { Lentils } \\ \text { Garden Peas } & \text { Sainfoin } \\ \text { Canada Field Peas } & \text { Fenugreek } \\ \text { Sweet Peas } & \text { Wistaria } \\ \text { Tangier Peas } & \text { Sand Clover } \\ \text { Pigeon Peas } & \end{array}$

Just add water and shake the bottle and sprinkle over seeds as directed. Your crop will benefit beyond your expectations.

No other inoculant on the market is so strong and virile; no other inoculant will thoroughly inoculate as much seed. The cne-acre size bottle of Farmogerm is sufficient for 20 pounds of clover, 25 pounds of alfalfa, 90 pounds of Canada field peas, 50 pounds of vetch, etc. Be sure to state what crops you wish to inoculate.

New methods of production have given lower prices. You cannot afford to do without Farmogerm.

A special composite culture is prepared for peas, beans, and sweet peas, 1/4-acre size only. You'll get more peas and beans, and larger sweet peas by using this. Ask for No. 5 , price 50 cts.

Farmogerm prices are: I-acre size, \$I; 3-acre size, \$2.50; I2-acre size, \$o. Full directions accompany each bottle.

Can't grow Alfalfa? YOU CAN with our seed and FARMOGERM! 


\section{STIM- O-PLANT}

\section{An All-the-Year Fertilizer for Garden and House Plants}

Growers of fine flowers, shrubs and vegetables for the best markets and for exhibition, fertilize and stimulate them frequently, a little at a time. An excellent fertilizer for this purpose is Stim-U-planT, an odorless, highly concentrated plant-food, in tablet form, with guaranteed chemical analysis of 11 per cent nitrogen, 12 per cent phosphoric acid, 15 per cent potash. The proportions are accurate, there is no unnecessary filler, and in this form you apply plant-food exactly when and where and as needed.

\section{Make Your Garden a Wonder Garden}

These tablets increase production, heighten color and improve quality. Many professional and amateur growers use them extensively all the year round--from early spring until late fall outdoors, during the winter for pot plants, hothouse benches, etc. They are equally as good for evergreens and large trees as for a small fern, petunia or other potted plant.

\section{Stim-U-planT Tablets}

can be used in tablet form, or dissolved in water at the rate of one tablet to the quart. Complete directions with every package.

Order Stim-U-planT tablets with your seed and plant order. Price, 10 tablets for 15 cts. 30 for 25 cts., 100 for 75 cts., 1,000 for $\$ 3.50$.

\section{At Last, a Perfect Spray SPRAY-TABS TBORDEAUX-ARSENATE TABLETS}

Irsecticide and Fungicide in Tablet Form

An entirely new departure in insect control and the prevention of disease among plants. The most convenient way. No more home mixing of offensive, poisonous ingredients from bulk packages; no more improper preparation of spray solution. Spray-Tabs solve the spraying problem. The one spray for all general garden use. Dispense with bulk spray materials and use Spray-Tabs for all leaf-eating or chewing insects and the prevention of plant diseases. The making of an insecticide and fungicide in combination in tablet form marks a new era in spraying.

\section{Prevent Plant Diseases While Fighting Insects}

Spray-Tabs combine convenience, reliability, and economy in a modern, efficient, and accurate insecticide and fungicide. The plant-grower has never before had the advantage of spray materials in tablet form. Spray-Tabs' safety and accuracy are alone sufficient recommendation. All that is needed to make an ideal spray for garden crops is to put the required number of tablets in a specific amount of water, agitate the solution and apply it to the plants. There is no opportunity to improperly make the solution.

Spray-Tabs - The New-Way Spray

Order them with your seed and plant order, that pest control may begin with garden making. Thirty tablets for $30 \mathrm{cts}$. Complete directions for every use with each package.

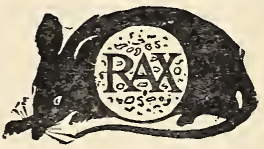

\section{SAVES MONEY BY SAVING CROPS}

It is estimated that rats and mice consume grain each year in the United States alone to the value of more than $\$ 10,000,000$. Most of this waste can be saved if $\mathbf{R a x}$ is given a chance.

\section{Rax Is Not a Poison}

While it is absolutely deadly to rats and mice, it is harmless to human beings, domestic animals, poultry, and birds. It may be used anywhere with complete safety.

\section{Rats Leave Before They Die}

Within a few days after eating food prepared with $\mathbf{R a x}$, rats and mice become feverish and seek the open air. Thus they never die indoors -always outside.

\section{How to Use Rax}

Add water to the bottle and shake contents until water is cloudy. Then moisten bait (bread, crackers or cheese) with the mixture and place it near the holes. $\mathbf{R a x}$ does not affect the taste of the bait.

Directions are furnished with each package. One bottle is enough for an ordinary house allow one bottle to each 500 feet of floor space in large barns, mills, etc. Price, 75 cts. per bottle, postpaid.

\section{How to Kill Mites and Lice on Poultry}

Spray PREVENTOL to rid your poultry of lice and mites, as well as chicken ticks, chiggers and stick-tight fleas. The presence of these pests is indicated by droopiness, dragging wings and ruffled feathers.

Spray your older poultry lightly with PREVENTOL. To free young chickens from these parasites, just moisten the tip of your finger with the liquid and rub gently under the wings and on the neck.

Spray it thoroughly in the poultry-house. Spray the roosts, walls, and ceiling. The common mites breed in the cracks of roosts and building, and come forth to suck the fowls' blond. If there is any litter about the poultry-house, spray this thoroughly. People who use PREVENTOL find it unnecessary to remove clothing and furs from dark closets and hang them upon lines in the sunlight; always a slow and laborious task. Instead, they spray it in the closet, over the clothing and furs. When woolen blankets, furs and clothing are packed away in chests or drawers, spray them regularly. If there are moths there, they will die.

It can be sprayed over the finest clothing without hesitation, for it causes no stains and contains no chemical that will eat the goods.

Prices: Combination package, Sprayer and pt. Preventol \$1.25; pt. Sprayer 65 cts.; pt. Preventol 60 cts.; qt. Sprayer $\$ 1$; qt. Preventol $\$ 1 ; 1 / 2$ gal. \$1.75; gal. \$3. 


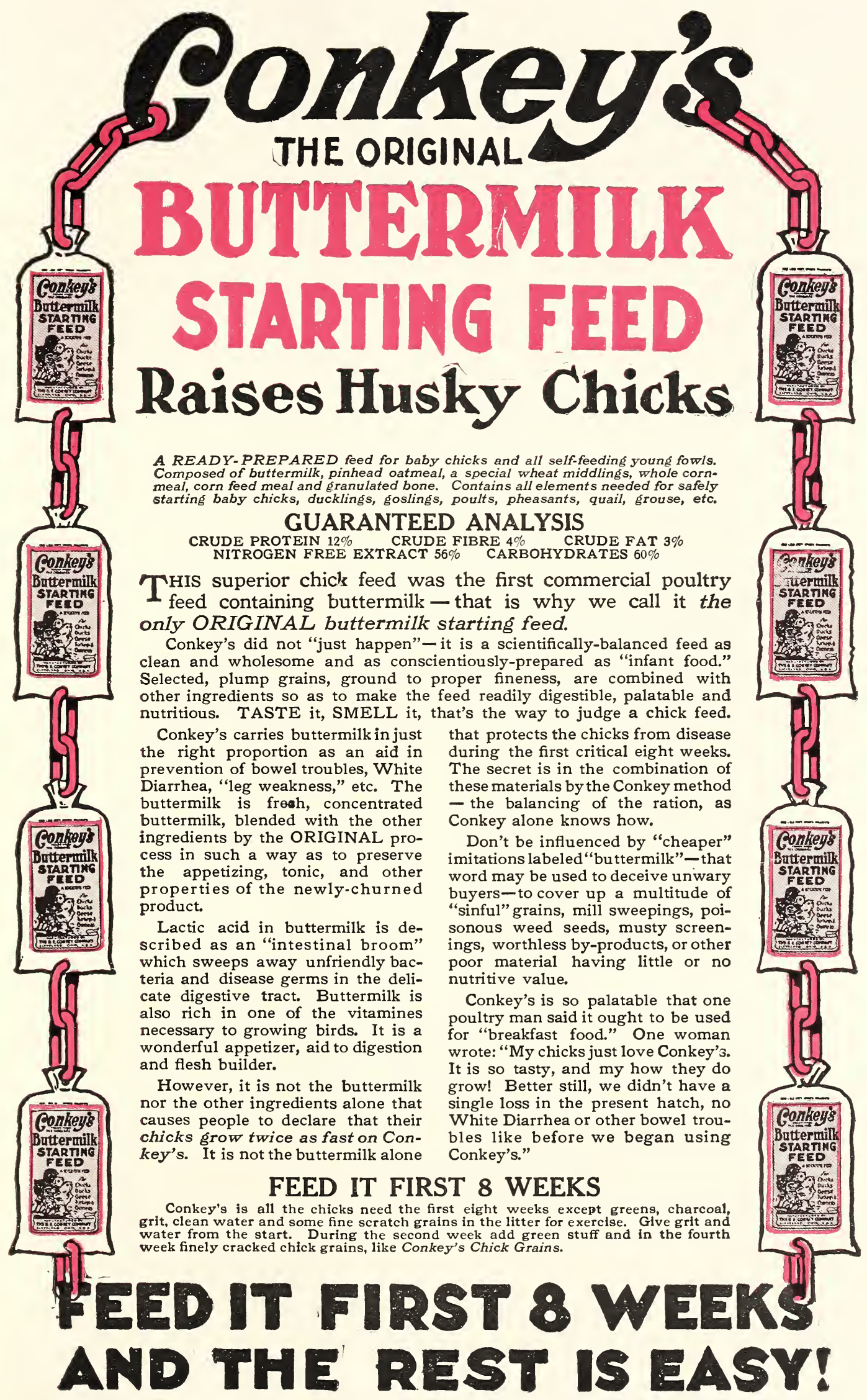




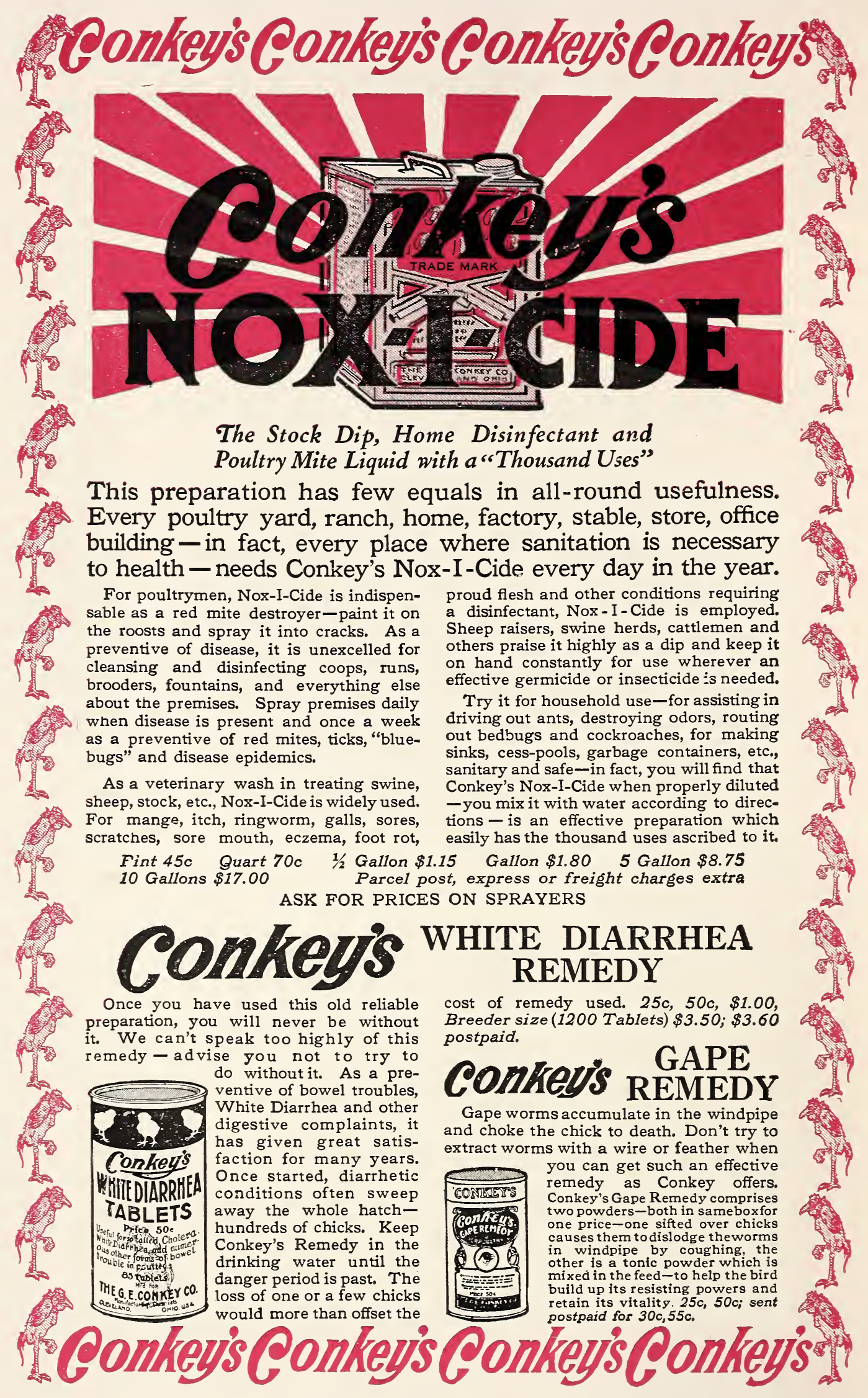


WE GIVE NO WARRANTY, express or implied, as to the purity, description, quality, productiveness or any other matter of any Seeds, Bulbs, or Plants we send out, and we will not be in any way responsible for the crop.

Prices of Seeds vary. We quote Market Values upon request and always give our customers the benefit of the lowest price that the market condition will warrant. Special prices on a general list will be given upon application. LET US HEAR FROM YOU.

We especially recommend to you the varieties marked with an asterisk ( $\star$ ), as being the best varieties of their respective types. You will be sure to be pleased with these varieties.

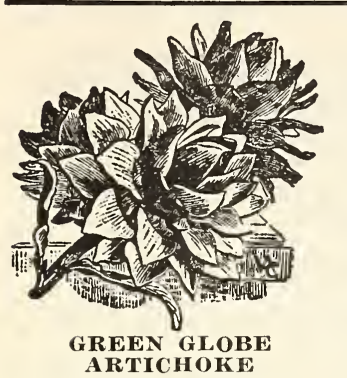

ARTICHOKE

The Globe Artichoke is cultivated for its flower-heads, which are cooked like asparagus. Plants set in any good soil, with slight coverings in winter, will remain in bearing several years.

Large Green Globe. The standard variety.

\section{ASPARAGUS}

Fr., Asperge.

Sow one ounce for sixty feet of drill. Sow in March or April, in rows one foot apart. When two years old, transplant into permanent beds, which should be well and deeply manured, and trenched to the depth of two feet. Set the plants (in rows) from three to four feet apart, and two feet in the rows, spreading out the roots and covering from six to eight inches. On the approach of winter cover with manure or compost; fork the beds early in the spring, and apply a dressing of salt. Cut for use the second year after planting in permanent bed.

\section{ASPARAGUS SEED}

Columbian Mammoth White. A new and entirely distinct variety that produces shoots that are white and remain white as long as fit to use.

Conover's Colossal. The standard variety; of large size, tender, and of excellent quality.

$\star$ Palmetto. It is of very large size, even and regular in growth and appearance. It is a very early sort, and immensely productive and of the best quality.

\section{ASPARAGUS ROOTS}

Two Years Are Gained if Roots Are Planted.
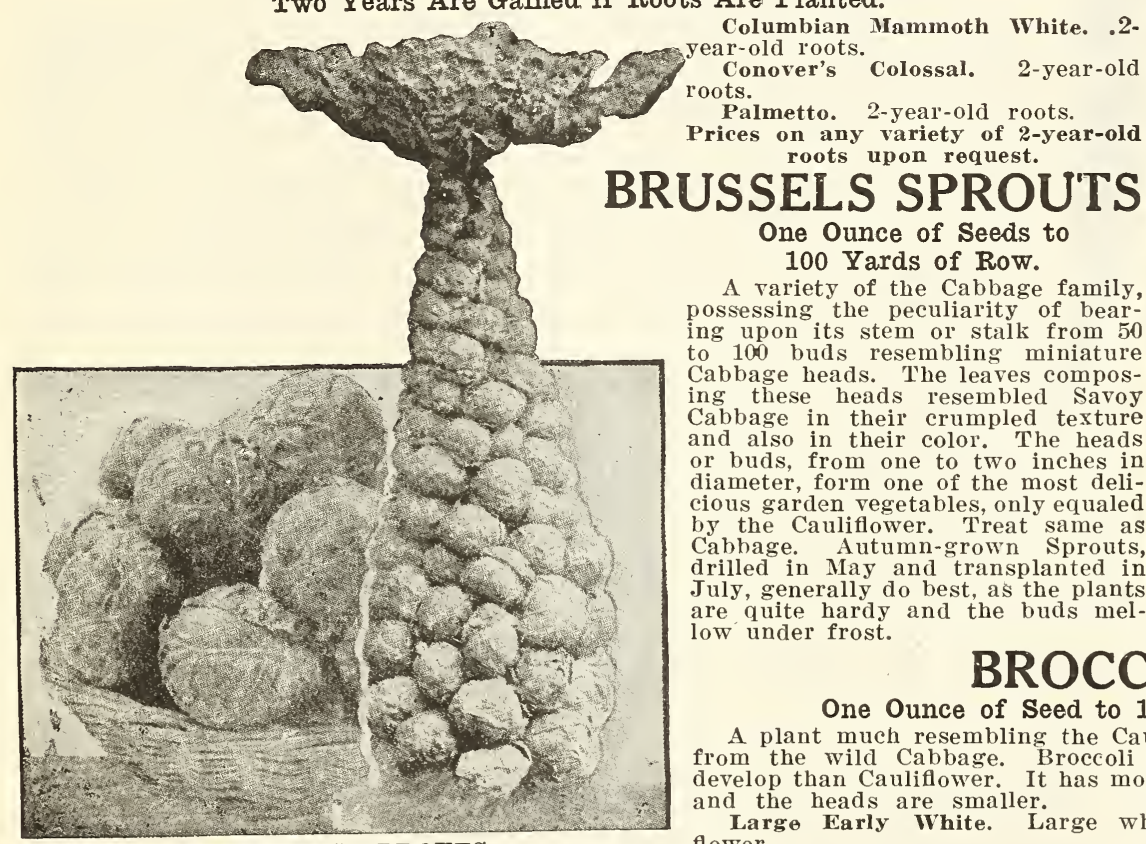

A variety of the Cabbage family, possessing the peculiarity of bear ing upon its stem or stalk from 50 to 100 buds resembling miniature Cabbage heads. The leaves composing these heads resembled Savoy and also in their color. The heads or buds, from one to two inches in diameter, form one of the most delicious garden vegetables, only equaled by the Cauliflower. Treat same as Cabbage. Autumn-grown Sprouts, drilled in May and transplanted in July, generally do best, as the plants are quite hardy and the buds mellow under frost.

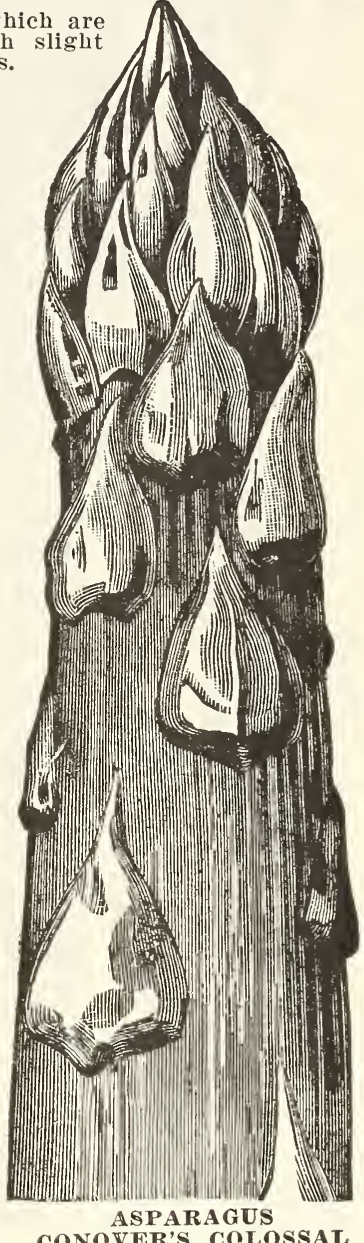

\section{BROCCOLI}

One Ounce of Seed to 100 Yards of Row.

A plant much resembling the Cauliflower, and, like it, derived from the wild Cabbage. Broccoli requires a longer season to develop than Cauliflower. It has more numerous and stiffer leaves and the heads are smaller.

Large Early White. Large white head, resembling Cauliflower.

\section{BUSH BEANS}

Beans are easily frost killed, so plant them at corn planting time on light, dry land. Cold, wet weather will rot the seed in the ground, and fresh manure causes a rank growth of vine with a lack of pods.

If hand cultivated, beans can be drilled in poor soil as close as eighteen inches; but in rich soil with horse cultivaIf hand ty-four inches. One quart should plant 250 feet and one bushel plants an acre. Expect a picking after six weeks. Plant every third week for a succession up till August 1st in the latitude of Chicago. Pick beans before the bulge of seed appears, and pick beans clean to continue the plants bearing. Give beans shallow cultivation, and do not till the soil when the plant is in bloom, or the plant in self-defense will drop
rust.

+Farly Red Valentine. For snaps there is nothing superior to this variety among the dwarf green podded sorts

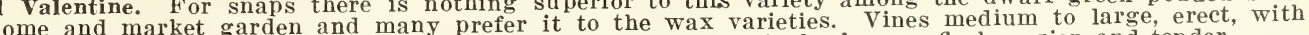
both for the hoves.

dark green leaves. Pods medium leng, ches in back, very feshy, crisp ands rather flat, \Black Valentine. A vory hard a little more spreading, and in season a little later. 


\section{BUSH BEANS, Green Pod-Continued}

Long Yellow Six Weeks. The vine is large, vigorous, branching and pro. ductive, with large leaves. Pods long, straight, thick, flat in shape, green in color, of good quality when young and fair as they near maturity.

Bountiful Beans. This new green podded Bush Bean is a heavy cropper and very early, of fine shape, stringless and good quality.

Extra Early Refugee. Very much earlier than the Old Style Refugee or 1000 to 1. More dwarf and compact in growth.

$\star$ Longfellow. This new bean has long green pods, is exceedingly prolific, always solid, a delicious flavor, is tender and remarkably early. It matures its crop very regularly and withstands adverse conditions well. A good bean for market or home use.

$\star$ Refugee or 1000 to 1 . The vines are large, spreading, exceedingly hardy, with small smooth leaves, very late, and bear long, cylindrical green pods of excellent quality. Highly esteemed for late planting.

$\star$ Giant Stringless Green Pod. A very hardy, stocky vine, pods long, round and green in color, of exceptionally fine quality and stringless throughout its entire growth.

$\star$ Burpee's Stringless Green Pod. A very desirable green podded snap sort for the home garden and largely grown for the market. The vine is vigorous, spreading and productive. The pods are larger than those of the Red Valentine, but are quite as fleshy, of equally high quality and remain crisp and tender longer.

Tennessee Green Pod. This dwarf snap bean, although new to the Seed Trade, has for sereral years been grown in the South, and wherever known is freely spoken of in terms of highest praise.

Dwarf Horticultural. Vines very productive, compact, upright, with large leaves. Pods medium length, cylindrical, curved, with splashes of bright red on a yellowish ground.

*Pheasant Eye. A valuable new green podded variety. Vines hardy, sturdy. well leafed. Pods long, meaty, stringless and of excellent quality.

Low's Champion. Large, green, flat, stringless pods.

French Bush Horticultural

Red Kidney

Improved White Kidney
Goddard or Boston Favorite

Nary

Boston Pea Bean

Large White Marrow

\section{DWARF LIMA VARIETIES}

As limas require even more heat than other beans, a failure will follow a too early planting. The beans when farorably planted throw out from what we term the bean's eye a stout root; this root in turn lifts the bean above the ground. The bean then opens its halves, or false leaves or cotyledons and the true leaves soon follow. If in planting the bean is thrust into the soil eye down and just below the surface, the bean is in a favorable position to begin its growth. However, the crop can be secured though with a lesser per cent of germination by dropping the bean in any position.

Bush limas are earlier than pole limas and are planted in twenty-four to forty inch drills, three to six inches apart in the row according to varieties. One quart plants one hundred twenty-five to one hundred fifty feet.

Treat pole limas like other pole beans, using one quart to one hundred hills. ŁBurpee's. The only bush form of the true, luscious, large lima. It is pronounced by all good judges as unquestionably the real Bush Lima. The bushes grow eighteen to twenty inches high, of stout growth and always erect. It is an immense vielder.

$\star$ Henderson's. This is a bush form of the small Sieva pole bean. It is the original bush form of the pole beans. It is the most productive of any, and on the whole is a vegetable of great merit.

Dreer's. The true bush form of the chubby Dreer's or Potato Lima. The pods are heary and thick. It is quite productive and of excellent quality.

New Wonder. This gives the largest and best returns-a big crop from a small space and is a decided improvement on the original type of Burpee's Bush Lima. The beans are of flat shape and fully equal in flavor to the famous Dreer's Bush Lima, so well and favorably known.

Foliage heavy and Very dark green in color. The stalks that produce the

BLACK VALENTINE blossoms are thrown out from the lateral and main stalks. The pods resemble Dreer's Bush Lima, but average more than double the size and contain from 3 to 5 beans to the pod.

\section{BUSH BEANS, WAX POD}

$\star$ Daris White Wax. This bean is adapted alike for the canner, market gardener, shipper or amateur. The dry bean is large, kidney-shaped, and white in color, making it one of the best for cooking in a dry state. Pods are long, meaty, flat in shape, and of a beautiful yellow color and fair quality.

Improved Golden Wax. Rust proof, an improvement on the old style Golden Wax. Pod is semi-round, Jellow, of good quality and has no string. Ready for picking 47 days from planting.

Detroit Wax. A distinct variety of recent introduction, which is worthy of a place in erery garden. The waxy, vellow pods are produced in great abundance and the quality is extra fine.

Prolific Black Wax. The old standard Black Wax Bush Bean. It is so good that it is worthy of special notice. The pods are round, brittle, of handsome golden yellow color, and of buttery fiavor when cooked.

*Pencil Pod Black Wax. Pencil Pod Black Wax grows a taller, stronger and more vigorous bush than the Improved Prolific Black Wax, which is one of its parents. The other parent is the Round Pod Refugee or Thousand to One, and from this latter source the Pencil Pod Black Wax gets much of its vigor, hardiness and productiveness, and its long, slender, straight, handsome pod, shaped very much like a pencil.

$\star$ Currie's Rust Proof Wax. An excellent Wax Bean in every respect. Rust proof, tender, thick flat pods of rery good quality. Very little string in early stages, developing a little when nearing maturity. Fit for table use 47 days after planting.

$\star$ Webber Wax. Unquestionably one of the best wax podded beans ever introduced. It is a market gardener's bean. having been originated in one of the best market gardening sections of the West. It produces a deep golden colored pod of good length; shape semi-round, thick meated, stringless and of exceptional quality. Vines strong, holding the pods well up, with good leaf covering and bearing in profusion.

Michigan White Wax. This splendid variety may be briefly described as a white seeded Golden Wax. It is one of the earliest of the dwarf, snap beans. The vines are very vigorous and unusually productive. The pods are golden jellow, fully as attractive as the well-known Golden Wax and of the same exceptionally fine quality. The seed is white, a most valuable feature heretofore unattained in a bush bean of highest quality. 


\section{BUSH BEANS, Wax Pod-Continued}

$\star$ Round Pod Kidney Wax. A very handsome midseason variety, especially desirable for snaps for the home garden. The plants are of strong growth, spreading and very productive. The leaves are large, broad and roughened. The pods are long and round, five and one-half to six inches, slightly curved, light yellow, wax-like, stringless and of the very best quality.

$\star$ Hodson Wax. The creamy-white flat pods are six to seven inches long, by three-eighths of an inch wide. The pods are late in maturing and are unusually free from blight or rust.

Wardwell's Kidney Wax. Hardy and productive, pods long, broad, thick, flat and of a delicate waxy yellow, of excellent quality and with no string in the early growth, ready for table 48 days from planting.

Refugee Wax. A perfect Refugee with Wax pods. Pods long, round and of a golden yellow color. One of the earliest, quality excellent, and is fit for picking 57 days from planting. A very fine canning bean.

Sure Crop Wax. A vigorous growing, very productive variety, similar in general appearance of plant and seed to Currie's Rust Proof Wax; the pods, however, are more fleshy, of decidedly better quality and are stringless at practically all stages of growth. Pods about six inches long, nearly round, attractive in color and remain a long time in condition for snaps. A decided improvement over Currie's Wax.

PLANT MORE BEANS.-Beans are very reasonable in price this year, particularly the green pod and wax varieties, as crops have been good, and as the green Beans have been bringing a good price in the market along with all other sorts of produce, more Beans should be planted for both garden and market purposes.

Now that the seed can be bought cheap and with the green Beans in such good demand, everyone should put out an increased acreage of Beans and.help reduce the high cost of living.

\section{POLE BEANS}

The pole bean climbs, sometimes needing a little training over any support given to it, be that support the growing cornstalk, rough stakes from the wood lot, bamboo or painted stakes, chicken wire or a convenient fence, supported wires or strings, or some porch or trellis. A good practice is to set firmly in the ground, every three or four feet each way, poles that are, when set, about six feet. Some time after bunch beans are planted, six or eight beans are planted on inch deep near the base of each stake and later thinned to three or four plants to the pole. One-half bushel of pole beans generously plants an acre, and one pint plants one hundred hills.

The pole bean bears over a longer period than the bunch bean and is generally considered of superior quality, but it requires more labor, longer time to mature, and is more sensitive to adverse climatic and soil conditions. Ninte that this vine turns only one way around its support.

When too old for use as a green snap bean, use any bean shelled, or still later, when it is hard and dry, it remains equally serviceable.

$\star$ White Creaseback. An extremely early Pole Bean. Vine small to medium and wonderfully productive. Bear.... pods in clusters of from four to twelve, and medium in length. An excellent shipper.

Red Speckled Cut Short (or Corn Hill). This is the best sort to plant in hills of corn. A great cropper.

$\star$ Kentucky Wonder. Vines vigorous, climbing well, and very productive, bearing its pods in large clusters; blossoms white; pods green, very long, often reaching nine to ten inches. Nearly round when young and very crisp, although as they reach maturity they become irregular and spongy. Dry Beans long, oval, dun-colored.

Kentucky Wonder White Seeded or Burger's Stringless. A very early, white seeded variety. Pods six to seven inches long, round, slender and straight; very tender, fleshy and stringless; of high quality; color dark green.

Lazy Wife. One of the most productive and easily gathered of the Pole Beans, hence its very discourteous name. A most excellent bean for the home garden.

ŁLondon Horticultural, or Speckled Cranberry. Vines moderately vigorous, bearing short, broad, pale green pods, becoming streaked with bright red as they near maturity. Beans large, oval and splashed with red. Used either green or in the dry state. Wax.

Early Golden Cluster Wax. One of the very finest polebeans. Very early, being only a week later than Golden

Kentucky Wonder Wax. One of the earliest of the pole wax sorts. Pods eight to nine inches long, thick, decidedly creasebacked, very fleshy, brittle but stringy, attractive and fair quality; color light yellow.

Dreer's Improved or Challenger Lima. This is a bean of rather peculiar shape, being thick and plump, rather than flat and oval.

$\star$ Large White Lima. The large Lima is a general favorite wherever it can be cultivated on account of its excellent flavor and productiveness.

t King of the Garden Lima. The old standard market and family sort. The vine begins to produce pods at the foot of the pole, and the bearing season continues until frost. Pods large, and well filled with beans of mammoth size.

$\star$ Small White Lima, Carolina or Sieva. Vines vigorous with many short branches, so that they are sometimes grown without poles; very early and productive, bearing short pods, which are thin and curved.

Scarlet Runner. Height, ten feet, with dazzling scarlet flowers from July to October; both ornamental and useful. It is used either as a string or shelled bean.

Dutch Case Knife. Vines moderately vigorous, climbing well and excellent for a corn hill bean; leaves large, crumpled, and pods very long, flat, green in color, becoming creamy white later. Beans broad kidney shaped, flat, and white in color. 


\section{TABLE BEETS}

As soon as the soil can be worked in spring, sow beet seed in twelve to eighteen inch drills for hand hoeing or eighteen to thirty inch drills for horse cultivation, dropping twelve seed to the foot. Cover the beet seed, which is really a beet fruit containing one or more seeds, one-half inch deep. Later thin the beets to stand five several weeks by starting under glass Use one ounce of seed to one hundred feet of row, and five or six pounds to the acre. Beets sown in early July should be ready to store in pits or in sand in the cellar when freezing weather begins.

$\star$ Early Egyptian. The well-known early variety. Color, extra dark; shape, flat; quality, excellent.

Early Eclipse. A very early maturing beet, especially desirable for the home garden. Top of medium size. Root nearly globular, with a small tap root and small collar. Flesh bright red, zoned with white; very sweet, crisp and tender, especially when young.

$\star$ Crosby's Egyptian Beet. The name of this variety is misleading, as it resembles the Egyptian only in its extreme earliness. They are also more spherical than the Extra Early Egyptian and, we think, of better quality. One of the best for early planting out of doors.

New Model. Extremely early, of perfect globe form and finest quality. The foliage is very small. The beets are always smooth and of the deepest blood-red color, while they quickly attain a good size.

$\star$ Crimson Globe. This is one of the finest beets yet introduced. Roots are not large, but very handsome. Round, and a clean, smooth surface. Leaves very small, with slender stems.

Edmand's Early Blood Turnip. The best sort for general crop. In quality one of the finest, exceedingly dark, shape globular, having only one tap root. Very popular with market men.

Dewing's Early Blood Turnip. A good rariery for main crop. Keeps well. Like Edmand's but lighter color.

$\star$ Detroit Dark Red Turnip. Quality good; sweet and tender; color deep red; roots are turnip shaped, with small tap roots.

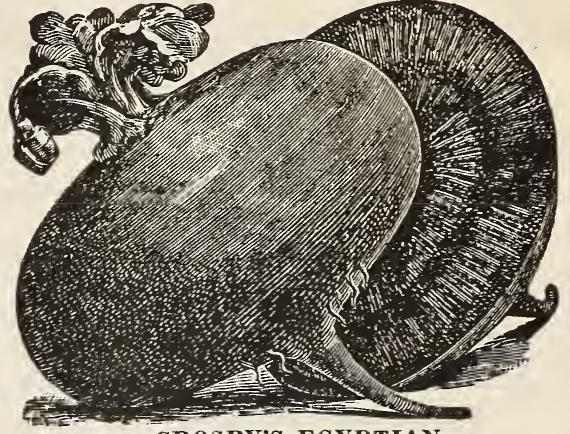

CROSBY'S EGYPTLAN

$\star$ Improved Blood Turnip. An improved rariety of Early Blood turnip of deep, blood-red color; fine form and flavor. An excellent market sort.

Long Smooth Blood. The standard long, late sort. Very dark, blood-red flesh, quality fine.

Half Long Blood. One of the best for winter use. The roots are only half as long as the Long Blood, but weigh as much on account of their thickness. They are always smooth and handsome, and their rich, dark red flesb is very sweet, crisp and tender, never becoming woody, even in the exposed portions.

$\star$ Swiss Chard, or Silver. This robust growing variety is often referred to as the Spinach Beet and is grown for its leaf, not for its root. The thick rib may be stripped from the leaf and used as in Asparagus while the rest of the leaf is served as "greens."

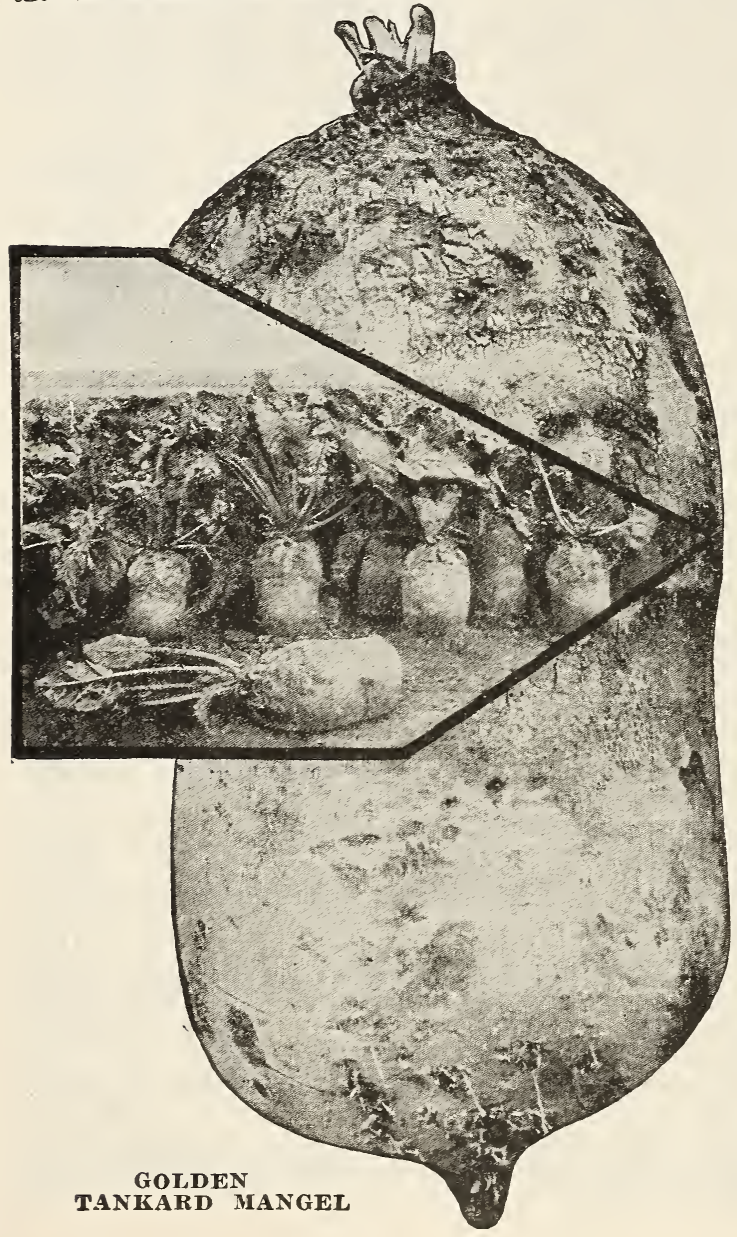

MANGEL WURZELS

Mangel Wurzel, called also stock beet, or cow beet, is a very large beet growing mostly above the ground and all stock eats it greedily. Plow the soil for it deeply. and in May or June plant six Mangel seed to the foot in two to three foot rows, later thinning to a ten inch two to three foot rows, later thinning to a ten inch
stand. One ounce sows generously one hundred feet of row. and an acre requires five to six pounds. When a light frost has occurred, lift the roots, store in pits or cellars, and the mangels are soon ready for feeding.

$\star$ Improved Mammoth Long Red. A large, long rariety grown for stock feeding. It stands up well above the surface; color, light red, flesh white and rose colored.

Norbiton Giant Long Red. Very large, excellent variety for feeding stock.

$\star$ Golden Tankard. Shape cylindrical, color deep rich yellow, flesh yellow circled with white. Unequaled for feeding stock.

Yellow Globe. Globular shaped roots. More productive than Long Red in shallow soil. Very nutritious and a good keeper.

Orange Globe. We think this one of the best rarieties of mangel wurzel.

\section{SUGAR BEETS}

The Sugar Beet, grown for the manufacture of sugar, and frequently used for stock feeding, is a yellowish white beet, smaller than the mangel, but containing a much greater per cent of sugar. In growing, the sugar beet is treated like the mangel, except that only six or eight inches of space is given each beet in the row.

Vilmorin's Improved Sugar. In general, the most desirable beet for the factor is the one containing the largest percentage of sugar. In this variety we have one of the richest beets in cultivation.

$\star$ Klein Wanzleben. A little larger than Vilmorin's Improved, vielding from twelve to eighteen tons per acre, and containing about the same amount of sugar. It grows below the surface, and the green leaves are rather large and spreading, with wavy edges.

$\star$ Giant Half-Sugar. This unites the large size of the mangel with the greater feeding value of the sugar beet. The roots average ten to twelve inches, and the outline is that of a broad, thick wedge. The upper portion is of a soft bright pink, shading lighter toward the bottom, where the lower portion for about one-third the length is white. 


\section{CABBAGE}

Cabbage grows successfully on a wide variety of soils, and experience points to liming, deep plowing and heavy manuring as successful practices.

Cabbage plants when properly hardened by gradually being brought to a low temperature and the quantity of water in them diminished, will stand any frost and some considerable freezing. Yes, a cabbage plant raised at a high temperature and full of water will be killed by even a light frost. Cabbage can be grown by planting the seed heavily where the crop is to grow and thinning the plants, but a better practice is to raise the plants without crowding in a seed bed which is not richer than the field to which the plants go, and transplant, if possible, on a cloudy day, a seed bed which is not richer than the field to which the plants go, and transplant, if possible, on a cloudy day,
watering the plants if the soil is dry. South of the Ohio seed is frequently planted out.of doors in September and wintered in coldframes, or in very southern localities the plant is fall-set on a shady side of the furrow, to aroid as much as possible the deadly freeze and thaw. For early cabbage north of the Ohio, sow seed in hotbeds in February, transplant to coldframes in March, and set outside in April, or sow seed out of doors as soon as the soil can be worked in Spring, covering the seed one-third inch deep. All vegetable plants are best when grown without check, so let as much soil adhere to the roots of the plant in transplanting as will hold and set up to the first leaf. At this time the plant should have four to five pairs of leaves and be four to six inches high.

Set small varieties to be worked by hand as close as eighteen inches each way, while large late varieties, horse cultivated, need thirty or more inches each way. A convenient setting for Wakefield Cabbage is eighteen inches apart in thirty-inch rows. Seven out of eight heads can be counted upon to mature, and if yourself or the market is cabbage hungry, cut when the hearts are solid. Germination occurs in four to ten days, and cutting of well-grown early cabbage begins frequently in sixty days from transplanting. One ounce of seed will readily give three thousand plants and one-fourth pound is sufficient for an acre.

For home use, plant for a succession and study the market's demands; don't grow big sauerkraut factory heads if your market asks for small cabbage for home use.

Late varieties are frequently ill-timed in planting. Nitrate of Soda will hurry the crop if too late, and if heads are so early as to begin bursting, push the head to one side far enough to tear off the roots on one side.

When club root appears, lime the soil heavily, and do not plant brassica-that is, cabbage, turnips, cauliflower and kindred crops-upon this sick soil for two or three years.

F'ight cabbage worms with Paris Green, Hellebore, or other good stomach poison.

For cabbage maggots, pour kerosene emulsion about the roots, or cut tarred paper in three-inch squares, split the square to the center, and place this collar on the ground about the plant when the plant is set.

For plant lice or aphis, use tobacco tea or kerosene emulsion, and remember, these poisons kill by contact and do not do their work long after spraying, like a stomach poison.

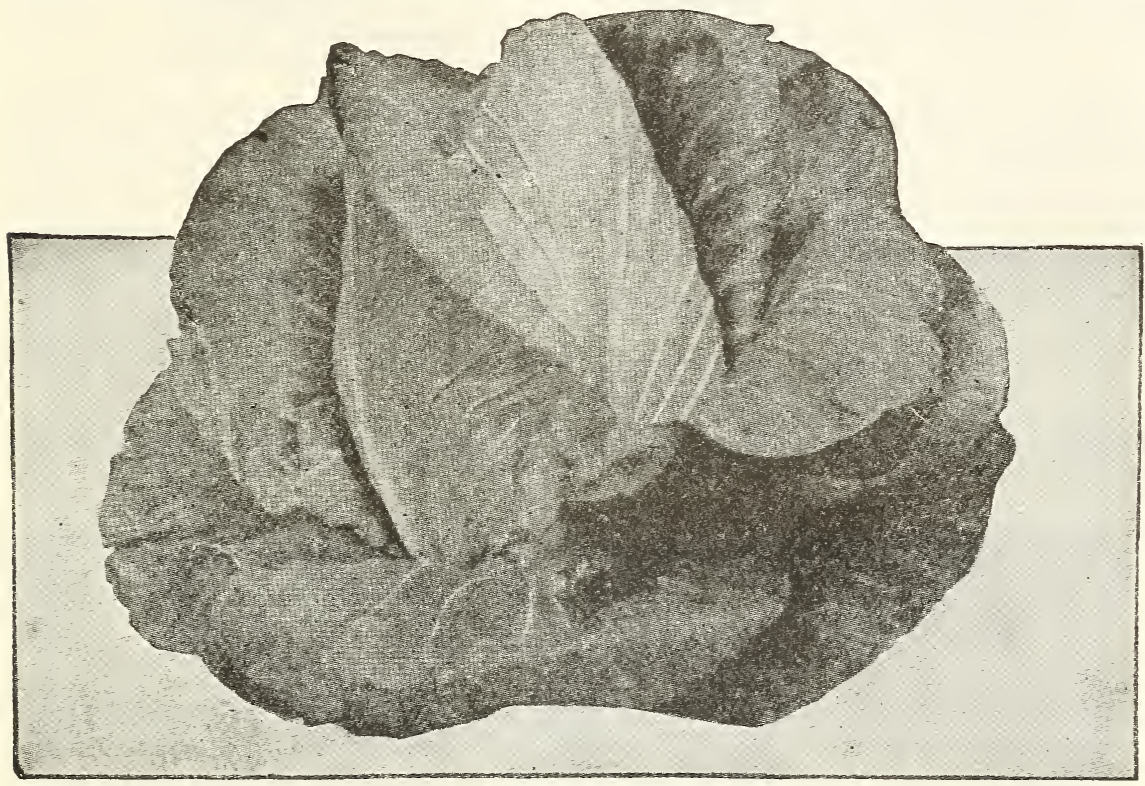

$\star$ Early Jersey Wakefield Cabbage. The most popular of the pointed head varieties. Is exceedingly early, a good cropper, heads of good size, solid and uniform.

L a $r$ e or Charleston wakefield. This is a selection from the best early Jersey Wakefield which will average about 50 per cent larger.

$\star$ Early Spring Cabbage. The earliest flat head, nearly as early as Jersey Wakefield. Yields more than the early pointed heads. Solid, uniform and finely grained heads.

tHenderson's E a r l y Summer. A standard summer variety. Heads large and solid.

$\star$ All Head Early. One of the finest early flat head cabbages.

EARLY JERSEY WAKEFIELD

†Faultless Cabbage. The favorite second early cabbage. The product of this seed outsells any other second early cabbage. It can be marketed in the early summer, during midsummer, in the fall and early winter, making it the best all-purpose rariety.

All Seasons. A fine variety for any season; a good shape and size.

Henderson's Succession. A good summer cabbage; also makes a good cabbage to succeed itself.

Early Dwarf Flat Dutch. An early cabbage of good size. Heads are flat and very solid.

Farly Winningstadt. An early pointed head variety of excellent quality, not as early as the Wakefield, but larger.

$\star$ Glory of Enkhuizen. This is an excellent midsummer variety. It comes in about a week earlier than All Seasons, makes a nice large head, has few outer leares, and can be planted close. Our tests show it to be worthy of a place among the new varieties of merit, and we can recommend it as a good addition to the list.

^Copenhagen Market. A new early variety, popular with market gardeners. It is one of the finest early roundheaded cabbages in cultiration. It is desirable on account of the remarkable characteristic of maturing the heads all at the same iime, enabling the grower to gather his crop with less expense and permitting the cleaning of the land at the first cutting.

Stein's Early Flat Dutch. An early and excellent type of Early Flat Dutch, with a medium stem; heads round, flat and solid.

Early Drumhead. This popular rariety follows the Faultless in heading and is one of the most valuable varieties grown

Fottler's Early Brunswick. An early fall variety, well known and popular.

Louisville Drumhead. This fine cabbage is very popular with the kraut makers. It is a medium late variety.

The kitchen gardener or critical market man who wants a quick and even maturing cabbage that resembles Danish Ball Head will find Glory or Enkhuizen and Copenhagen Market unquestionably the best. 


\section{CABBAGE-Continued}

Buy Cabbage Seed carefully. Select the best variety for the purpose wanted and know that you have the best seed to be obtained.

$\star$ Premium Flat Dutch. This variety of late cabbage is a standard in all sections for winter use. It makes a large solid head, which keeps long without bursting, and is adapted to a more varied climate than probably any other variety we grow.

Sure Head. A fine variety for main crop. A good shipper and sure header.

Iarge Late Drumhead. A late variety of large size.

$\star$ Improved American Savoy. Closely approaching the cauliflower in delicacy and delicious flavor. The best of all the Savoys for general market or home use. It has a short stump, grows to a large size, is compact and solid, and is a sure header.

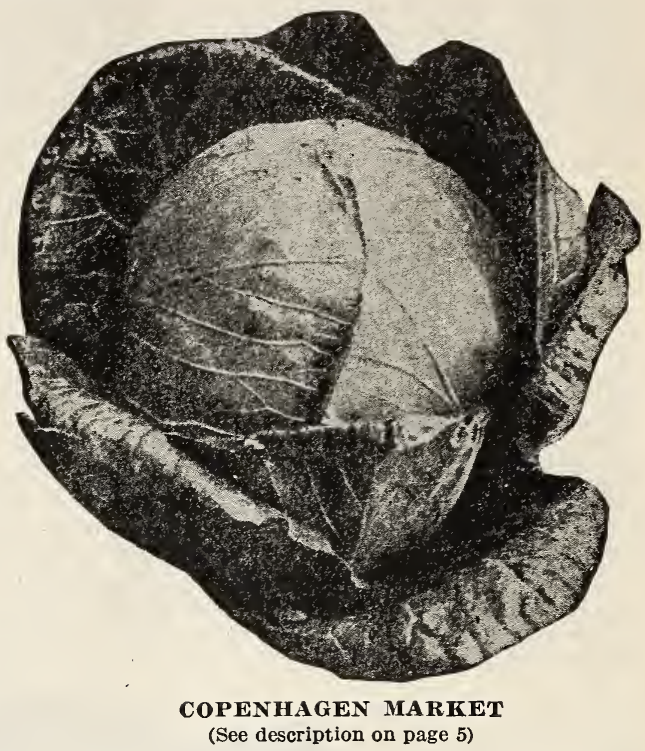

Wisconsin No. 8. A "yellow" resistant strain of cabbage. The disease resistant properties of this variety apply only to that known as the "yellows" and no claim is made that it is less susceptible to other forms of disease such as Black Rot, Black Leg or Club Root, than other sorts. Although showing considerable variation in type, the plants resemble Hollander, but are larger and more leafy and spreading. The heads are round or somewhat flattened. For localities where cabbage plants are affected by the "yellows" we earnestly recommend a planting of this new strain.

Red Drumhead. The standard pickling variety. A good keeper.

$\star$ Mammoth Rock Red. The largest heading of any red sort. Heads are hard, of deep red color, quality excellent.

Chinese Cabbage or Pe Tsai; sometimes called Celery Cabbage; resembles Cos Lettuce as much as cabbage, though with a decided cabbage flavor.

Danish Ballhead Cabbage. For a winter cabbage for early spring sales some gardeners consider this variety excellent. It has been selected and perfected for more than fifty years by the Danish gardeners, who prize it so highly that they grow it almost exclusively for winter cabbage, and annually export large quantities of it. It is a hard heading, and long keeping cabbage. Heads round as a ball, solid, fine grained, has few outer leaves, tender, crisp and of unexcelled flavor.

$\star$ Holland. The favorite winter cabbage with market gardeners. It is as hard as a rock, and a small head will weigh as much as a large head of any other variety. The leaves lap over and make a head in which there is no waste.

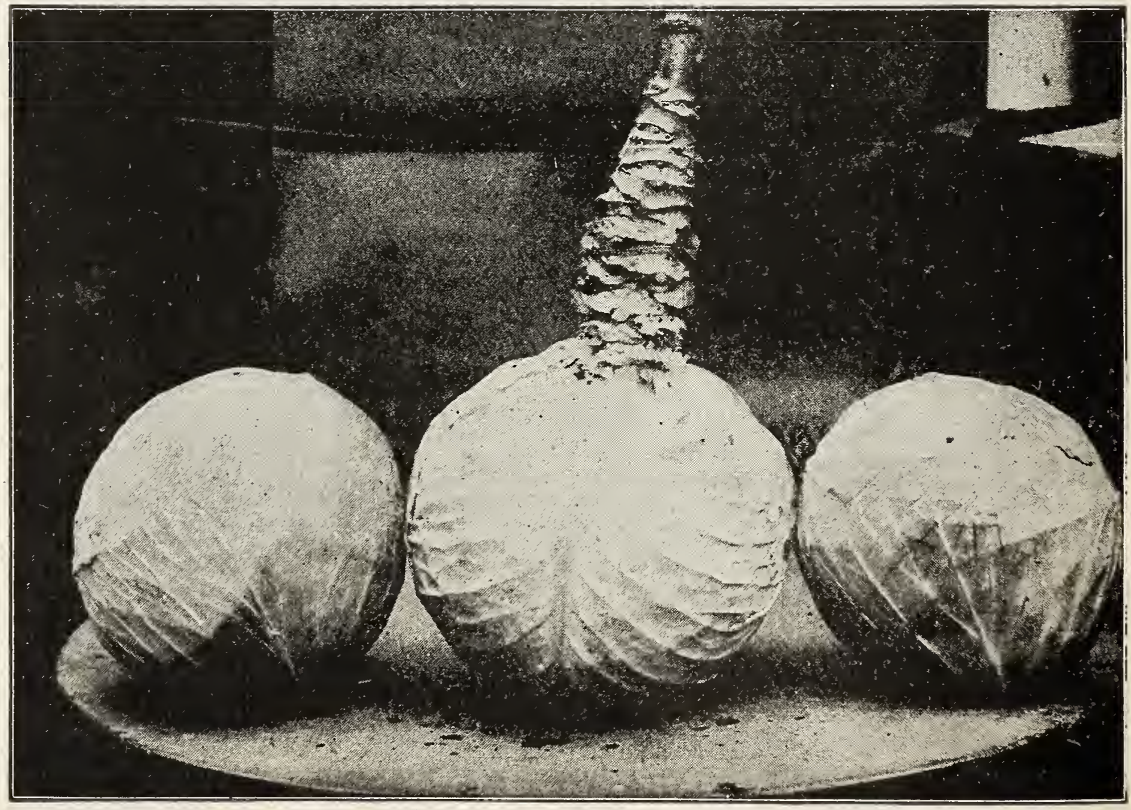




\section{CARROTS}

The carrot, whether used raw, iried, boiled, or stewed; used alone or combined with other vegetables or meat, is not surpassed in nutritious healthfulness by any other vegetable catalogued. Plant carrots, in the latitude of Chicago, from the time the soil can be worked in Spring till July 1, in one to two foot rows for hand cultivation, or in thirty inch rows where a horsedrawn tool is used. Use one ounce of seed to one hundred feet of row, three or four pounds to the acre, covering one-half inch deep, and later thin to a four inch stand. To cultivate the rows at an early date, sow radish seed, which germinate quickly, with carrot seed, which germinate slowly. Do not overlook the value of this crop as a stock food.

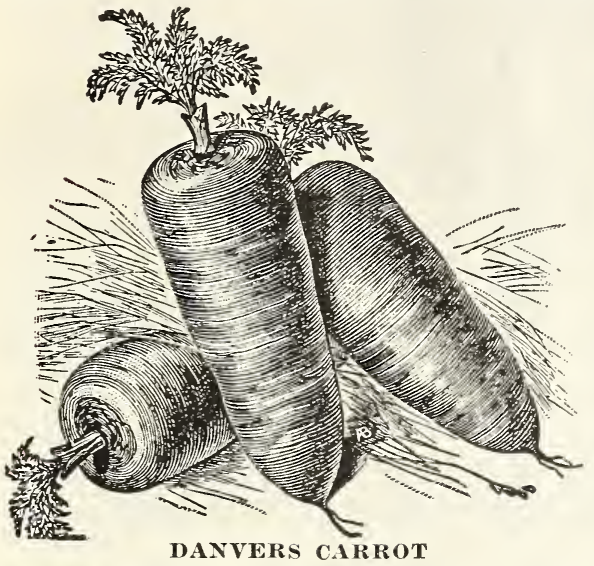

Early Short Horn. A fine early variety, good for home use. Eastern market gardeners use this sort for bunching.

$\star$ Chantenay. Tops medium size; necks small; roots tapering slightly, but uniformly stump rooted and smooth; color, deep orange red; flesh very crisp and tender. Although this is a medium early sort it furnishes roots of usable size as early as any, is a heavy cropper, and is undoubtedly one of the best for both the market and private garden, while its great productiveness makes it very desirable as a field sort.

Guerande, or $0 x$ Heart. Tops small for the size of the roots, which are comparatively short, but often reach a diameter of 7 inches, terminating abruptly in a small tap root. Flesh, bright orange fine grained and sweet. This is a desirable variety, for soil orange, and stiff that longer growing sorts would not thrive in it. When young. excellent for table use, and when mature equally good for stock.

ŁDanvers. Grown largely on account of its great productiveness and adaptability to all classes of soil. Tops medium sized, coarsely divided. The smooth and handsome roots are deep orange, of medium length, tapering uniformly to a blunt point; flesh sweet, crisp, tender, and of a deep orange color. This is a popular field variety, and although the roots are shorter, they produce as large a bulk as the longer field sorts and are more easily harvested.

$\star$ St. Valery. A good late variety. Grows long, shape uniform, tapering from a wide shoulder to a point.

ŁImproved Long Orange. The most popular of the older sorts for farm use on mellow soil. An improvement obtained by vears of careful selections of the best formed and deepest colored roots of the old Long Orange. Roots comparatively shorter than the Long Orange, and smoother, but so uniform and true that the bulk of crop will be greater.

Large Orange Belgian. Quite similar to White Belgian, except in color. Roots 20 inches long, broad and pointed; light orange below the surface, green above.

$\star$ Large White Belgian. Grows one-third out of the ground. Root pure white, green above ground, with small top. Flesh rather coarse. The roots on light, rich ground, grow to a large size and are extensively grown for stock feeding.

\section{CAULIFLOWER}

Cauliflower, while it resembles cabbage and requires very much the same treatment as outlined under and for cabbage, is not so hardy as cabbage, needs more water, needs more cultivation and requires generally treatment superior to cabbage. Cauliflower cannot be expected to mature satisfactorily in hot, dry weather, and as it requires one bundred ton to ane hund rectly timed. Start cauliflower under olass or where cabbage plants can be wintered, winter cauliflower. Cne ounce gives two thousand five hundred plants, and one-fourth to one-half pound of seed plants an acre. When ounce gives two thousand five hundred plants, and one-fourth to one-half pound of seed plants an acre. When
the head or heart of cauliflower, as you may think or feel of it, called the "curd," appears, tie the outer leaves over the head or pin these leares with wooden pins or beef skewers, so the leaves will shade and blanch the curd, and then cut the curd before it starts to branch. Remember that all the enemies of cabbage emphat ically attack cauliflower and are to be combated in a like manner.

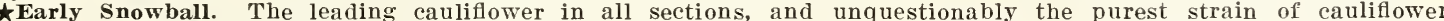
ceed to be had. Heads uniform, of desirable market size and of snow w whiteness. After seven years' competitive tests it is pronounced by expert cauliflower growers to be the best for both early and late planting.

Danish Dry Weather. We take pleasure in introducing this cauliflower to our customers. It is from one of the best growers in Denmark and we recommend it highly to market gardeners for trial. It is claimed to be a splendid strain for a dry season and equally good in all weathers.

Autumn Giant. A late sort of fairly good quality. Will do well under favorable conditions.

\section{CARDOON}

Smooth Solid Cardoon. Grown for the mid ribs of the leaves which are blanched and used in the same manner as celery. The main root is also used and when cooked in a proper way. is excellent. Thorough blanching is necessary in order to bring out the delicacy of flavor possessed by the Cardoon.

\section{CHERVIL}

A hardy annual, worthy of more general use for flavoring and garnishing.

Sow in early spring in rich, well prepared soil, and when plants are well established transplant to about one foot apart.

Curled. Greatly superior to the old, plain rariety, being earlier, more handsome, and having fully as fine perfume and flavor.

\section{CHICORY}

Witloof or French Endive. The principal merit of this variety consists in the width of its leaves and the large size of their ribs. When blanched, it forms the vegetable which the Belgians call Witloof. When properly grown and blanched it resembles a head of Cos Lettuce.

Large-rooted, or Coffee. Our stock is the Improved type, with very much larger, smoother, whiter and proportionately shorter roots than the old kind. The dried and prepared roots are used quite extensively as a substitute or adulterant for coffee.

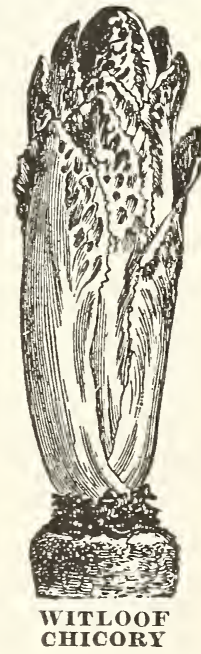




\section{CELERY}

Press celery seed into the ground; do not try to cover it; and when seed is kept wet and not above $60^{\circ} \mathrm{F}$., germination occurs in ten to twenty days. Celery needs four to five months from seed to use, so very early celery should be started in hotbeds after.January, and when two inches high transplanted or thinned to a space of two inches. Later trim the tops to produce stocky plants, and when five inches high set.where plants are to mature, first trimming off onethird of the roots and leaves. Celery seed may be planted out of doors north of the Ohio in April and treated as outlined above. Given sufficient water celery can be grown on any good garden soil, and one ounce of seed gives above 6,000 plants.

When almost grown, celery must be blanched; that is, the light is excluded from the edible stock by the use of boards, earth, paper or other covering. If boards are used, rows can be set as close as thirty inches; if earth blanched, fortyeight inches or more is better. Set the plants six inches apart in the row and press the soil firmly about the roots. Again, celery is set in solid beds eight inches each way, and the shade of the crowded bed does the blanching. With a few stalks in a garden, a tile set over the plant or wrapping of paper an-

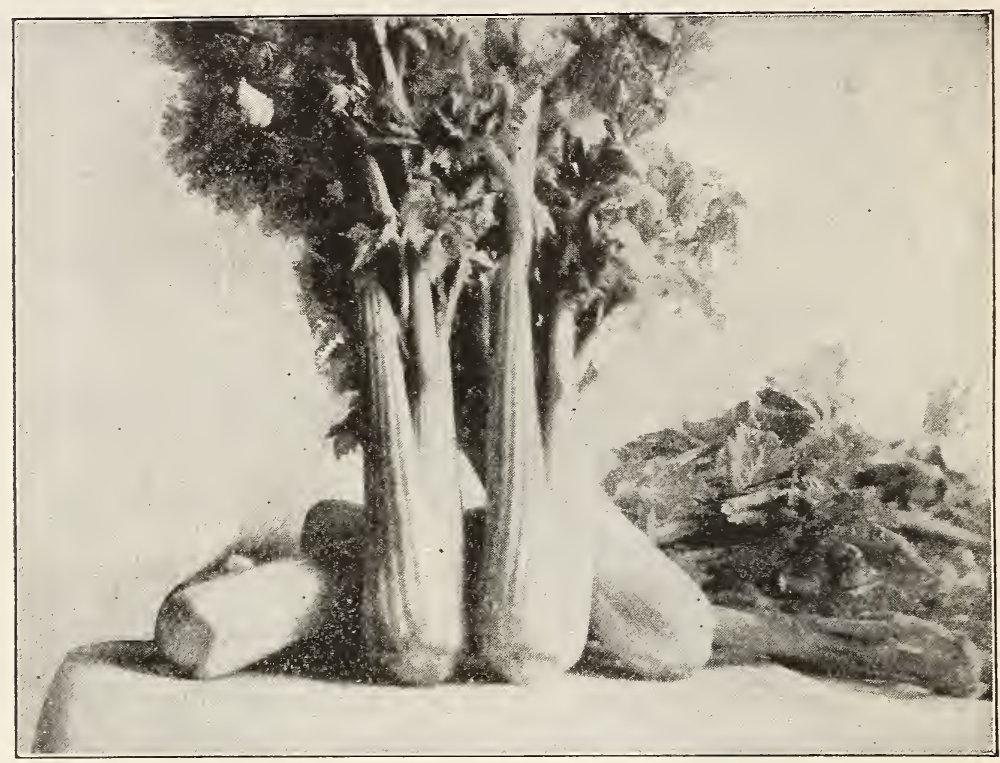

GOLDEN SELF-BLANCHING swers the purpose. If earth is used

in blanching it should be drawn about the plant to one-third its height and repeated twice a few days apart till leares only are exposed. Do not cultivate hill or disturb celery when damp, or rust may occur. In this hilling with earth called handling place a peg at end of row with string to it and pass string about each plant so as to prevent earth from falling into the heart during the work. To store, celery should be only partly blanched.

When freezing begins, lift plant with some soil and store in a cave, coldframe or cellar, temperature close to freezing point preferred. Use slats to keep celery in long six-inch wide spaces, for if too deeply packed it may heat and spoil. If plants wilt, water the roots, not the stalks.

Celery matures best in cool, moist weather, so the grower farther south may delay this planting calendar to fit his own market and convenience.

^GoIden Self-Blanching. The best self-blanching sort. It acquires a handsome golden color without having to be hilled up, which makes it a valuable market sort.

*Henderson's Easy Blanching. Excels in the qualities that give Self-Blanching Celeries their value. It bleaches earlier and quicker than any of this class; it is the longest keeping variety grown (if put away green), excelling in this respect every other sort.

†White Plume. A good self-blanching sort, good for fall use, but does not keep well.

Boston Market. For many years one of the most popular sorts in the markets of Boston.

†Giant Pascal. This is the best keeper of all of the late sorts; very solid and crisp. This variety is unsurpassed for market garden.

Giant Golden Heart. This variety attains a large size, but still remains crisp and tender. It is a fine keeper and is the favorite on the Chicago market.

Perfection Heartwell. A finely flavored, good keeping sort, hardy and solid.

Kalamazoo. This is the variety used by the celebrated celery growers of Kalamazoo, Mich., and is of great merit.

Soup or Cutting Celery. This variety is adapted to sowing thick in rows and cutting when three or four inches high, to use for soup flavoring.

\section{GERMAN CELERY OR CELERIAC}

Large Smooth Prague. Has a large smooth root, and is the finest of all celeriac.

\section{CRESS}

True Water Cress can be easily grown by sowing the seed broadcast on garden soil and keeping the soil very wet till the plants are big enough to transplant to shallow indentations about five inches deep here and there along the sides of a clean flowing stream. There it will continue to spread by the lengthening of its roots, also by reseeding, and requires no further care. The crop can be grown to maturity in wet garden soil, or the seed can be sown directly to the mud along the stream, but with lesser measures of success. April or September is a good time to plant these minute seeds, and this aquatic prefers to stand with its roots and most of its stems submerged. Cutting can begin in about sixty days, and a little later frequent cutting, using a sharp knife, will stimulate plant growth.

Curled or Pepper Grass, a pungent, quick-growing plant that poorly parodies the water cress flavor, can be grown in any garden soil as soon as the ground can be worked. Plant one-half inch deep in one foot rows, thinning the plants to four inches.

\section{COLLARDS}

Georgia, Southern or Creole. A variety of cabbage known in different sections as "Cole," "Colewort," or simply "greens." It is extensively used in the south, where it continues in luxuriant growth all winter.

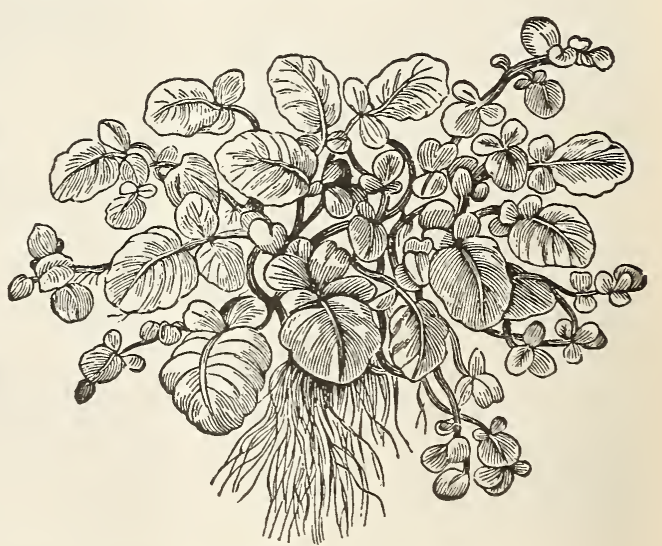

TRUE WATER CRESS 


\section{SWEET CORN}

Plant corn every two weeks for a continuous supply, and north of the Ohio from late April to late July. Plant corn in three or four foot drills, dropping a grain every eight to sixteen inches, or plant in hills three or four feet each way, giving six grains to the hill and later thinning to three stalks. Corn should be planted about one inch deep, planted deeper in sand than in heavy clay; planted deeper later in the year when the soil is warm; dwarf varieties closer together than the larger ones; and a given quantity of seed of a small grained variety plants a larger area than does a like quantity of the large grained. One quart generally plants two hundred fifty hills, and one peck is necessary to the acre. Sixty-five days is a short time to maturity. Plow deeply for corn, cultivate shallow, and pick corn before it is too old. If the goodness of new corn tempts a too early planting, do not blame the resulting failure on your seedsman.

$\star$ Golden Bantam Sweet Corn. A very early sweet corn with golden yellow grain, very tender and of excellent quality. The ears are six to seven inches long and of the medium size found most suitable for the table. The flavor is exceptionally rich and delicious. Our stock has been very carefully selected. Height about four feet. Early Cory Red Cob. This variety is the favorite for first early, and no other variety
has proven earlier.

White Cob Cory. This is an improvement over the Early Cory, as the cob is white, which gives it a finer appearance. It is as early as the Early Cory and of excellent quality.

Mammoth White Cory. The ears are twelve rowed, white cobbed, and covered with very large white grains of good quality.

Premo Sweet Corn. A "sixty-day" sweet corn, and is thus described by the originators: "It not only combines all the merits of the leading early varieties, but it is also really superior to them all in size, quality and yield. Premo can be planted fully as early as the Adams for the young plants withstand slight frosts."

Howling Mob. One of the finest second early, large eared sorts; very productive, white and of excellent quality. Ears 7 to 9 inches long, 12 to 14 rows.

Extra Early Adams. This is an extra early field variety, but is much used as an early market variety, being sweet and juicy.

$\star$ Early Minnesota. One of the standard early sorts. Ready for market two weeks later than Cory or Chicago Market.

Crosby's Early. An early corn of large size and choice quality. It has long been a standard variety.

Kendall's Early Giant. A valuable early sweet corn.

Potter's Excelsior or Squantum. Fine, large ears and deep grain; one of the sweetest varieties.

\#Country Gentleman. We have a stock of this excellent sweet corn that is exceptionally good. There is no sweet corn that compares with the Country Gentleman for sweetness. It is the variety par excellence where'quality is desired. Market gardeners who make a specialty of growing for hotels and high-class restaurant trade use this as a main crop rariety in preference to any other. For home use it will be found superior and it is very productive. The fact that it is a favorite variety with canners proves its merit.

old Colony. This variety is two weeks earlier than the Evergreen and almost as large.

Early Evergreen. The ears of this new corn grow eight inches long, are mostly 14 to 18 rows.

$\star$ Stowell's Evergreen. This standard main crop variety excels all other late sorts in sweetness and productiveness. It is more popular than any other for canning, for marketing and for the home garden. Great care has to be exercised in the selection of stock to grow seed from, as this variety has a tendency to deterioration and a shorter grain,
which makes it less sugary and desirable.

Mammoth Sugar. A large late variety having ears of mammoth size, 14 to 20 rows.

Black Mexican. This corn, when in condition for the table, cooks remarkably white; but the ripe grain is black or bluish-black.

ŁLeonard's Narrow Grain Evergreen. This new type of sweet corn is a stock worked up by S. F. Leonard after sereral years of experimenting. In it we feel that we have something vastly superior to the old wide grain Evergreen. The ear is as large as the Stowell's Evergreen and averages more rows to the ear. The cob is small in to the size of the ear, and the kernels are very long, narrow and remarkably free from starch. The rows are uniformly straight and the ear holds its evenness from butt to

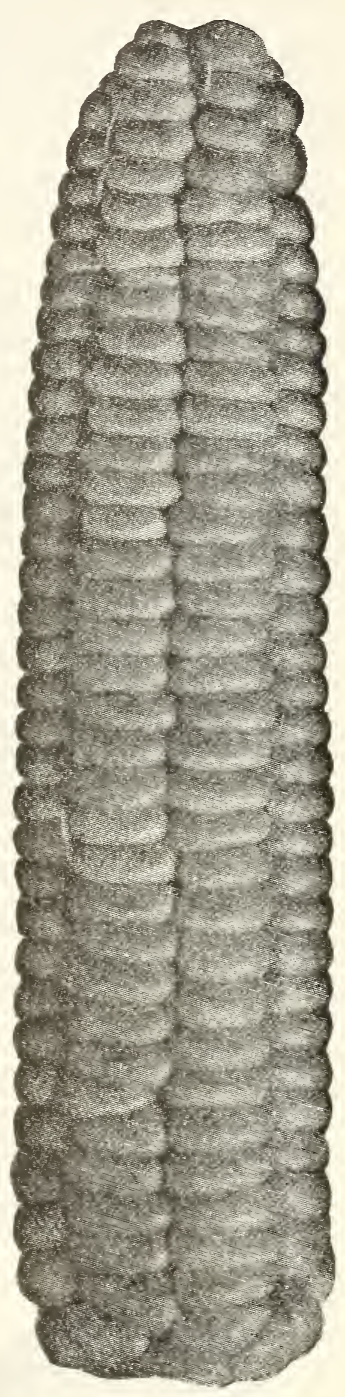

GOLDEN BANTAM

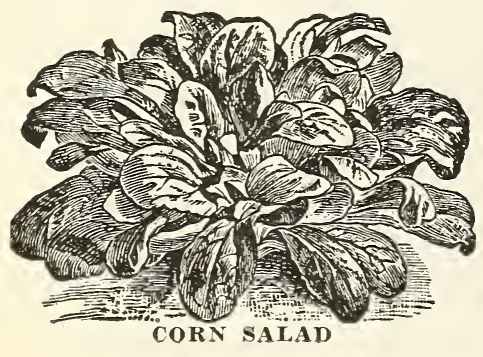

\section{CORN SALAD}

Fetticus, or Lamb's Lettuce. This small salad is used during the winter and spring months as a substitute for lettuce, and is also cooked and used like spinach. In warm weather the plants will mature in four to six weeks. Sow the seed in shallow drills about one foot apart. If the soil is dry it should be firmly pressed over the seed in order to secure prompt germination. On the approach of severe cold weather, cover with straw or coarse litter. Like most salad plants, greatly improved if sown on very rich soil; indeed, the ground can scarcely be made too rich for them. 


\section{CUCUMBER}

Not before corn planting time plant cucumbers out of doors in drills or hills onehalf inch deep. The crop may be advanced two weeks by starting in the hot bed or greenhouse on inverted four-inch sods covered with leaf mold. The plant will appear in four to eleven days and in three weeks from seeding, when the plant has two to four leaves it is ready to transplant outside.

Mark the field up and down hill, then furrow across its face in a four-foot check and at each intersection drop manure or fertilizer, or better, both. Throw earth to this intersection to form an elongated hill four inches high. Plant the seed like a short drill not haphazard; then later two strokes of the hoe cleans this short drill.

Be generous. Use a dozen seed to a hill, and after the striped beetle has his toll, thin to three plants to a hill. To check the beetle, use on foliage, but not too heavily, road dust, ashes, air slaked lime, bone flour, tobacco dust, or arsenate of lead; pull earth about the stem or cover the hill with netting.

Cultivate as long as possible. Cut the cucumbers. Do not pull or bruise them and to keep the plants bearing, çucumbers must not be permitted to ripen.

Early Cluster. Vines vigorous, producing the bulk of the crop near the root and in clusters. Fruit short, uniformly thick end, dark green, but paler at blossom end. A very productive sort.

Green Prolific or Boston Pickling. A favorite with pickle growers and commercial gardeners, and good for table use. Quite productive. Fruit small, uniform in size.

Early Frame or Short Green. An excellent sort both for table use and for pickling. Fruit straight, handsome, smaller at each end, bright green; flesh tender and crisp, and makes fine pickles.

$\star$ Chicago or Westerfield Pickling. A variety esteemed above all others by Chicago market gardeners and extensively grown for the large pickling establishments in this vicinity. Fruit medium length, pointed at each end, with large and prominent spines. Color a deep green. It combines all the good qualities of an early cucumber.

†Improved Long Green. Not so abundant a bearer as the preceding sorts, though recommended to all who put up their own pickles. Fruit long and slim, not surpassed in quality by any variety.

*Early Improved White Spine. One of the best sorts for table use. Vines are vigorous, fruiting early and abundantly; fruit uniformly straight and handsome, dark green, with a few white spines; flesh tender and of excellent flavor.

Evergreen White Spine. Is the most profitable cucumber for the market gardener. Best for the greenhouse, hot bed or for outdoor culture.

$\star$ Davis Perfect. In color, a dark, glossy green; shape, slim and symmetrical, with an average length of ten to twelve inches. They hold their color until nearly ripe, when they turn white.

Klondyke. A medium early, very good strain of white spine; fruits attractive, full, uniform, rather thick, short and blocky, tapering abruptly at both ends; color very dark green which it holds well.

Early Fortune. The finest market cucumber of the White Spine type. The fruits measure nine inches long and are slightly tapering. The thick flesh is pure white, firm, and unusually crisp, with very few seeds. The fruits are of a rich, dark green color which does not fade when shipped to distant markets.

Lemon. This little cucumber is not half appreciated for the home garden. It has a most delicate flavor, and nerer gets bitter or unfit for the most demanding taste. The vines are prolific-the fruit is small and always in good condition.

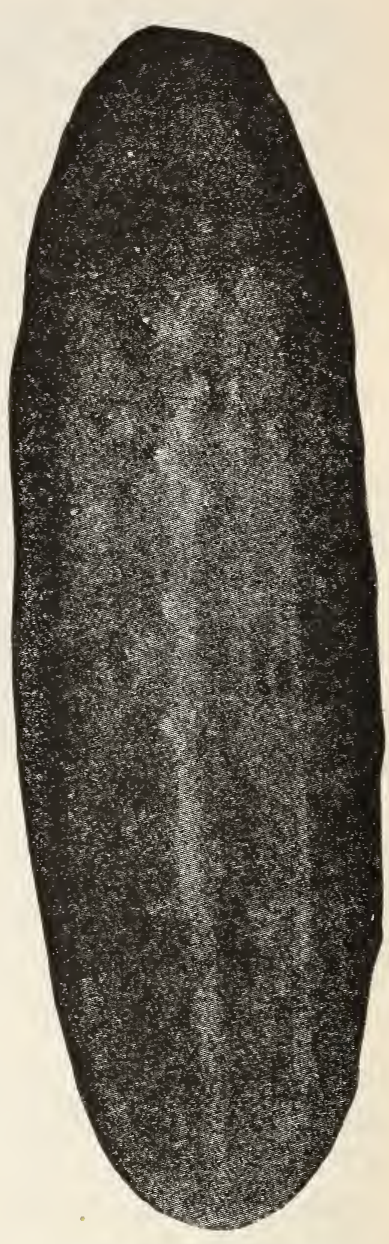

IMPROVED WHITE SPINE

\section{DANDELION}

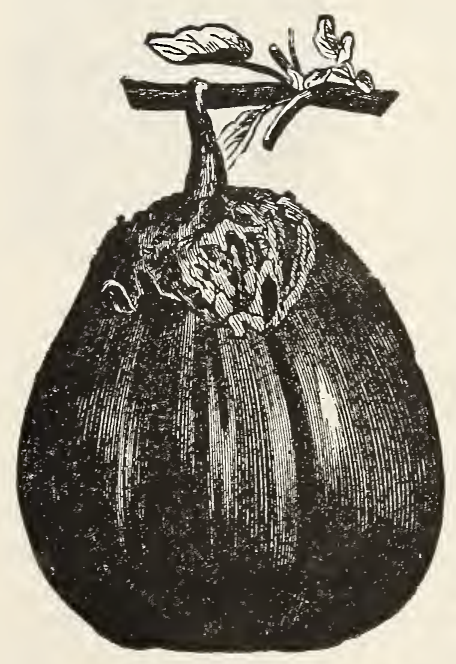

EGG PLANT
Cultivated or French Common. This is considered the best by many and is not at all the same as our wild dandelion, being greatly improved by careful selection.

Improved Thick Leaved. One of the earliest and best greens cultivated.

\section{EGG PLANT}

Treat the egg plant like a tender tomato that required even a longer period to nature. After cabbage plants are out of the hotbed or greenhouse, which is April north of the Ohio, sow egg plant, keeping eren the night temperature above seventy degrees. One ounce of seed gires two thousand plants, and one pound plants an acre. Transplant later to pots or to a three or four inch stand, and when corn is shoe high, put egg plant outside on rich, well drained land. Set the plants two feet apart in four feet rows, shading or watering the plants if it's sunny or dry. Use any good stomach poison for the potato bug when he attacks the egg plant.

$\star$ Improved New York Purple Spineless. Very large and smooth, fine dark color. Ours is the spineless plant, most preferred by our market gardeners, both east and west.

Black Pekin. A fine variety, bearing large, round, deep purple fruits, fine grained, and of superior quality.

Early Long Purple. Early, hardy and productive; excellent for the table. 


\section{ENDIVE}

Endive, or winter lettuce, used as a salad, as greens or garnishing, is usually planted one-fourth inch deep in a seed bed in midsummer, and when convenient after a month transplanted to stand one foot apart in eighteen-inch rows. When almost grown and about two weeks before ready for use, it is blanched by tying the leaves together with soft cord, or the blanching is by turning a flower pot or tile orer each plant, or by blanching with earth, like celery. The blanching removes the green. plant's acrid taste. The plant may be, but seldom is, used as an early spring crop. Three to five pounds of seed plants an acre.

$\star$ Green Curled. Beautifully curled, tender and crisp.

Moss Curled. More finely curled, and a heavier and more dense plant than Green Curled.

White Curled. Very tender when cut young; blanches readily.

*Broad-Leaved Batavian. (Escarrole.) This rariety is chiefly used in soups and stews; requires to be tied up in blanching.

\section{AROMATIC, MEDICINAL AND POT HERBS}

Most of the varieties thrive best on rich, sandy soil, which should be carefully prepared and well cultivated, as the zoung plants are for the most part delicate and easily choked out by weeds. Sow as early as the ground can be made ready, in drills sixteen to eighteen inches apart, taking pains that the soil is fine and pressed firmly over the seed; or they may be planted as a second crop, the seeds sown in beds in April, and the plants set out in June. Most of them should be cut when in bloom, wilted in the sun and thoroughly dried in the shade.

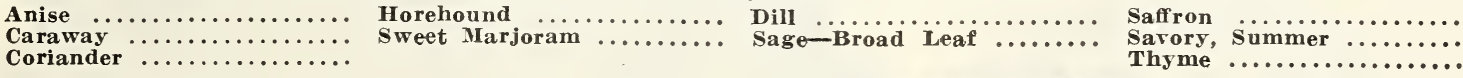

\section{KALE OR BORECOLE}

In Virginia, kale planted in late August has some of its plants thinned out and sent to market within sixty days and the cutting then continues until the field is clean in April. Further north, kale is treated like the cabbage; that is, planted early in spring in hotbeds or out of doors, and it is used in the fall when light frosts have improved it. Kale is sown in two or three foot drills and thinned to six to twenty-four inches, according to varieties. One ounce sows generously one hundred yards and foul pounds plants an acre.

^Dwarf Curled Scotch. Leaves bright green, curled, very tender and fine flavored; an excellent sort for private gardens.

Siberian Kale, or Winter Sprouts. This is also called German Greens and is sometimes sold for Dwarf Green Curled Kale, but it is not as curly as the Dwarf Curled Kale and is different from it in color. The leaves are smooth in the center, having a fringed edge. Color has a bluish tint, not the deep green of the Dwarf Curled Iiale.

Dwarf Green Moss Curled. Leares yellowish green, very compact and beautifully curled; sow in September for winter and early spring use.

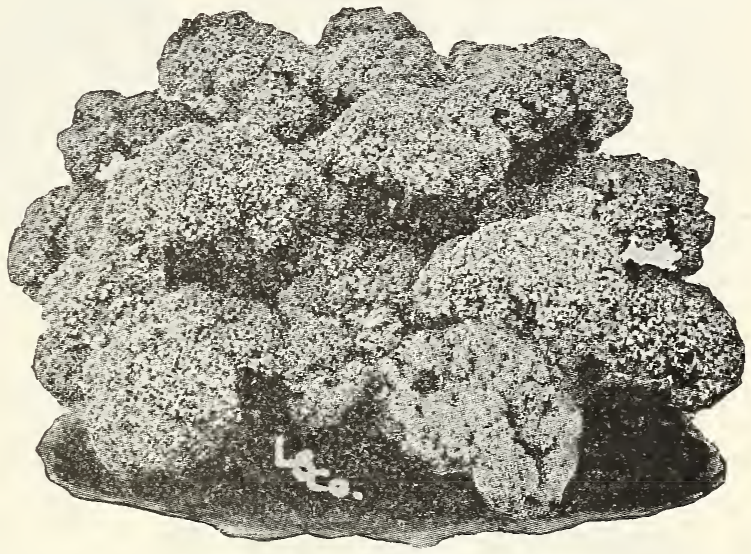

DWARF CURLED SCOTCH KALE

\section{HORSE RADISH}

Horse radish produces no seed, but is grown from pieces of the roots.

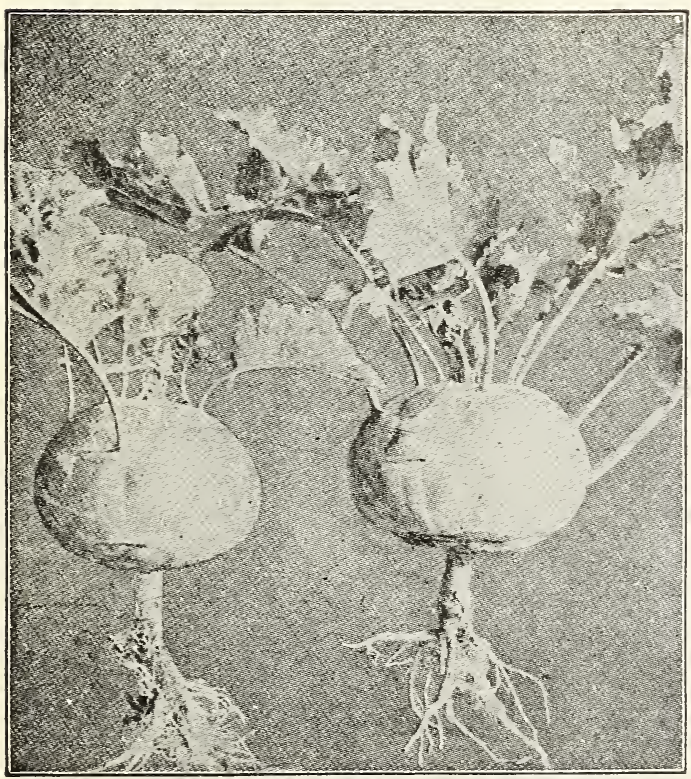

EARLY WHITE VIENNA KOHL-RABT

\section{KOHL-RABI}

This relative of the cabbage, that looks like a turnip that grew above the rround, cabbage or turnips. One ounce sows one hundred yards and four pounds plants an acre. Sow in eighteen to twenty-four inch rows, thin to four inches apart and use for the table when small. Like the turnip, we cannot expect good kohl-rabi in the summer heat, but a planting made about August 1st north of the Ohio will give a crop for winter storage. Do not overlook the value of this plant as a stock food.

Early White Vienna. 'The finest for market. Flesh white and tender.

Early Purple Vienna. Bluish purple; similar to above, except in color.

\section{LEEK}

This mild member of the onion family is used in soups and salads. Sow one ounce to one hundred feet of row or four or five pounds to the acre, one-half inch deep, as early as the soil can be worked in the spring. Thin the plants to a stand of four to six inches in the twelve to eighteen inch rows. It is advisable to throw earth to the plant to blanch it, very much as celery is blanched.

†Large American Flag. Large, hardy and of excellent quality.

Monstrous Carentan. The favorite market variety, large, thick stem, of mild flavor and attractive appearance.

Large Musselburgh. Grows to a Very large size, with broad leaves, spreading like a fan; hardy, of excellent quality.

London Flag. An old and popular sort; one of the hardiest and best for winter use. 


\section{LETTUCE}

As lettuce will stand considerable freezing, it may be seeded or transplanted out of doors as soon as the soil can be worked in spring. For a succession, replant every three weeks till within sixty days of freezing weather. The soil cannot be made too rich and this crop must be grown quickly and unchecked to be of superior quality. North of the Ohio lettuce is frequently started under glass like cabbage in hotbeds; in February transplanted to cold frames and hardened to be set out of doors in early April. In more southern or milder winter climates, lettuce may be sown in autumn, protected with sash or coarse litter and in late winter transplanted; or thinned and matured where planted. When the crop is matured under glass it requires much ventilation and little heat, and beware of too much water in cloudy weather. In the summer's heat canvas or a slatted half shade and plenty of water is of value. One ounce of seed gives two thousand plants and three pounds plants an acre. In the seed bed drop twenty-five seed to the foot, and gently rake it in; failure may result from too deep a covering. Mature lettuce in twelve to eighteen inch rows, giving the loose leaf varieties three to eight inches in the row and head lettuce six to twelve inches.

Black Seeded Simpson. This is the most popular early sort on the market. Forms large, loose heads. Leaves thin and exceedingly tender, of light green to golden vellow. Best sort for forcing or outdoor early planting.

Early Curled Silesia. A very tender sort, with fine curled leares.

Grand Rapids Forcing. Preferred by a great many to the Black Seeded Simpson, on account of being a tougher leavea lettuce. This makes it a fine sort for shipping, as it does not break so easily and stands longer without wilting.

Early Curled Simpson White Seed. Forms a close, compact, mass of curly yellowish green leaves. Good for cold frames or early planting for outdoors.

Boston Curled. Curled leaves of good quality, a popular variety among eastern growers.

Prize Head. The leaves are very large, crimped, bright green tinged with brownish-red and are exceedingly tender, crisp and sweet, forming a large, loose head.

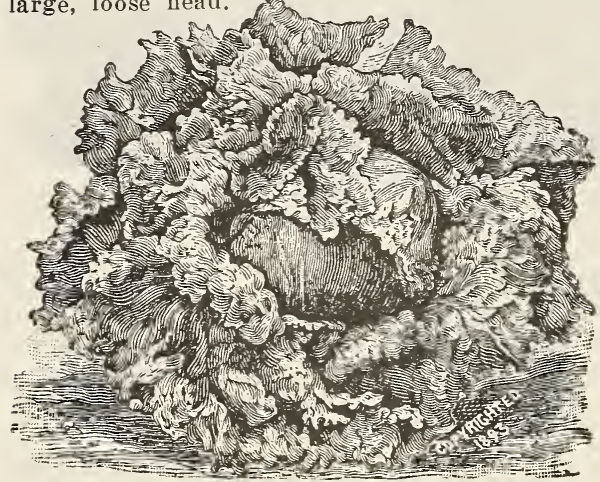

IMPROVED HANSON

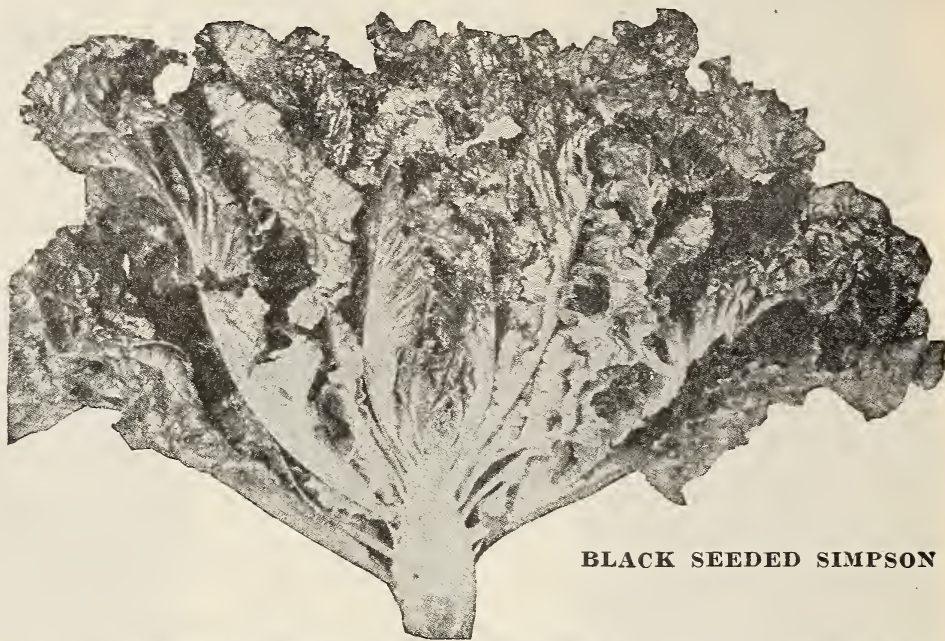

Improved Hanson. Heads large, hearts quickly and stands the summer well; quality excellent.

Early Tennis Ball, White Seed. A good early sort, and used largely by eastern gardeners for forcing.

Early Tennis Ball, Black Sced. A good lettuce for early use. The heads are small, but very crisp and solid.

St. Louis Head. The most popular and satisfactory head lettuce with market gardeners. It forms a fine head, is tender and crisp, and is very slow to run to seed. Outer leaves are lignt green, and the inner ones are bright, creamy cellow, of a very fine flavor. Altogether, we recommend it as being the best head lettuce for general use.

All Seasons. One of the best head lettuces, standing the hot sun better than any other sort. Slow to seed.

The Leonard Lettuce-Cabbage head-is the head lettuce for early and late summer planting. Produces a very fine early large solid head, color a fine light green, free from spots. Small ribbed leaves
that are very tender and crisp.

Big Boston. This variety is identical in color, shape and general appearance with the famous Boston Market Lettuce, but is souble the size. It is about one week later in maturing, but its solidity and greater size of head will make it a most valuable sort. A most desirable variety, either for forcing in cold frames or open ground planting.

The Deacon. A magnificent butter head lettuce It stands the hot weather without becoming bitter or running to seed, and bears fine, large heads of superb quality. Light green outside, and within a beautiful cream vellow of delicious rich, buttery flavor. Highly recommended for home, or market use.

New York or Wonderful. The large white heads resemble cabbage in their solidity, and frequently weight two and three pounds each The quality is superb, being crisp, rich and tender. It withstands the heat well, making a fine variety for all seasons.

California Cream Butter. A grand, good butter lettuce. The heads are of good size, round and solid; outside, medium green; within the leaves are a rich cream yellow color. Rich and buttery in taste.

Paris White Cos. The Cos lettuce differs entirely in shape from the other rarieties, the head being elongated and of conical form, eight or nine inches in height, and five or six inches in diameter. To be had in perfection it requires to be tied up to insure blanching.

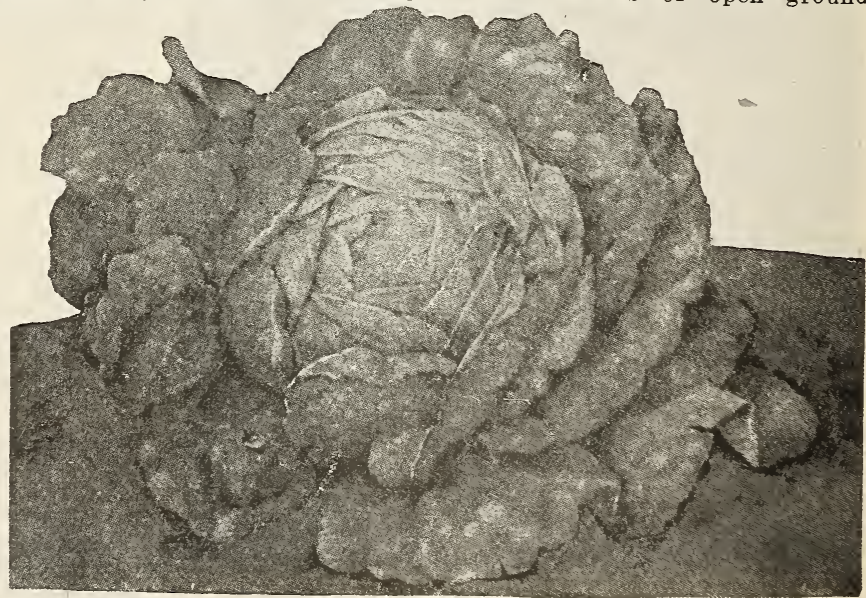

BIG BOSTON 


\section{MUSK MELON}

Musk melon, watermelon, cucumbers, gourds and squash are known as cucurbits. For musk melon follow our cultural directions for cucumber except that where a robust growing variety of musk melon is grown, a space of as much as six by six feet is sometimes required between hills. One ounce of seed plants fifty hills, and three pounds plants ail acre. The crop or the last planting for a succession should be in by June, north of the Ohio. While not necessary, it is advisable to pinch off the branches of the muskmelon if a quicker matured or a larger or a better fruit is required. Pick the melon when it parts from the stem without diffculty and store a few days in a cool

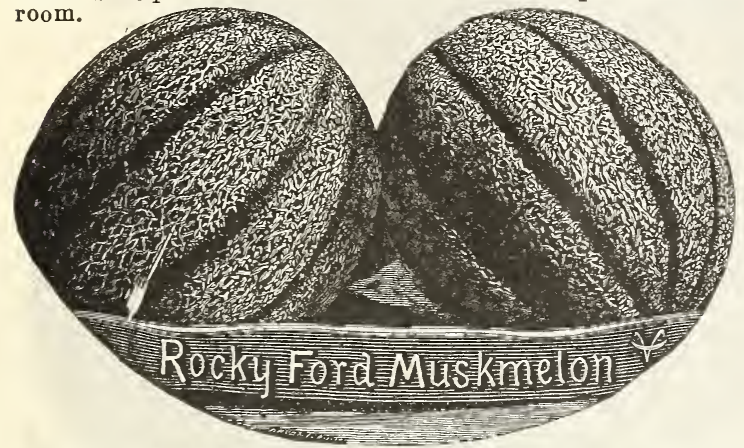

Early Hackensack. The fruits are nearly two weeks earlier than Hackensack, medium to large sized, nearly round or somewhat flattened, evenly and deeply ribbed and with very coarse netting. The skin is green, slightly tinged with yellow as the fruits mature. The flesh is green, a little coarse but juicy and sweet.

Hackensack, or Turk's Cap. A very large, green fleshed melon. The vines are hardy, vigorous and productive. The fruits are nearly round, usually somewhat flattened; ribs large and of irregular width, densely covered with coarse netting.

Chicago Market. This we consider the best Nutmeg for earliness of maturity, large and uniform size, thickly netted skin, small seed carity, deep green flesh, juicy delicious flavor and freedom from rot. A favorite with all who prefer a green flesh sort

Burrel Gem. This is an orange fleshed netted Gem or

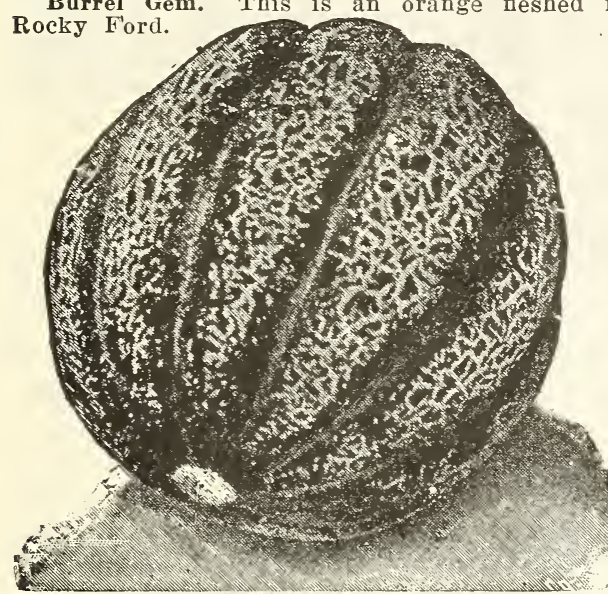

THE OSAGE MUSK MELON
Rocky Ford. This has become one of the most popular of small or crate melons and is shipped in large quantities from Colcrado and Arizona. The vines are vigorous and productive. The fruits are oval, slightly ribbed, densely covered with fine netting. Flesh green, very sweet and flarored.

Jenny Lind. Vines rather small but vigorous and productive Fruits small, somewhat flattened, deeply ribbed and well netted. Flesh green and exceedingly sweet.

Netted Gem. The kest early melon known. Shipped to every market of note in great quantities every year. Medium size, but of excellent flavor.

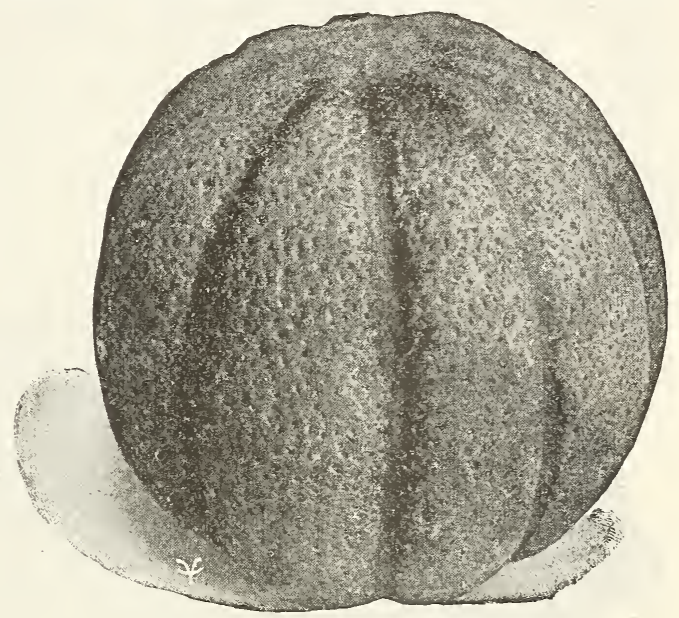

HOODOO, OR HEARTS OF GOLD

Hoodoo, or Hearts of Gold. A new orange fleshed variety, ideal as a shipping melon and of the very finest quality. Vine vigorous, remarkably blight resisting and 5ery productive Fruits uniformly of medium size. Netting exceptionally fine and dense, extending practically over the entire surface.

Paul Rose, or Petoskey. A yellow fleshed sort of suitable size for a crate melon and of excellent quality. Vines vigorous and productive. Fruits oval, slightly ribbed and densely netted.

Emerald Gem. A very early, yellow fleshed melon of small to medium size. One of the very best for the home garden.

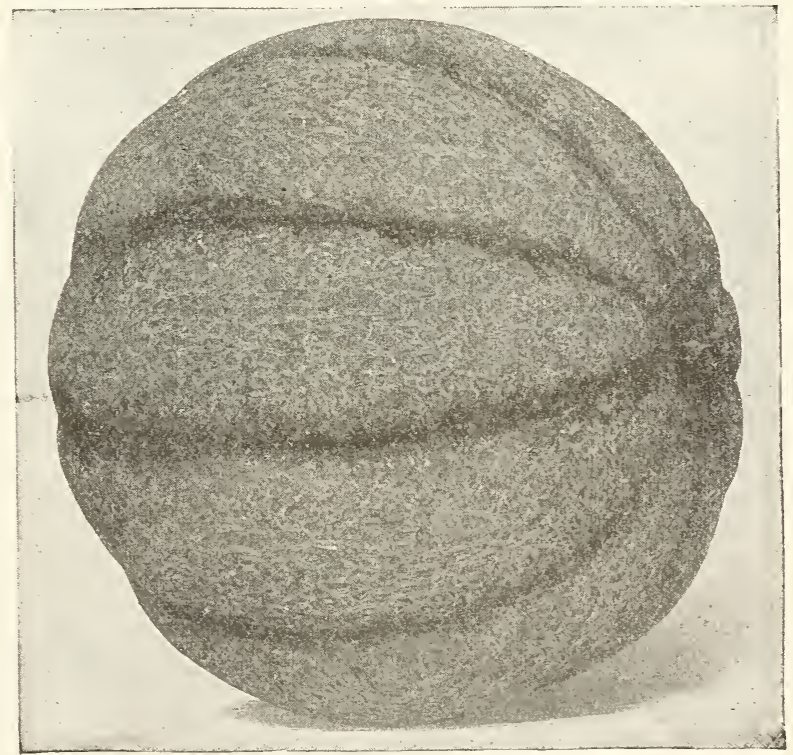

TIP TOP MUSK MELOY

The Osage. Is of medium size, oval in form, dar green in color, somewhat netted and slightly ribbed. The flesh is extremely and uniformly thick, of firm texture, rich salmon in color; highly flavored and delicious to the rind. Cavity very small. It is a remarkable keeper and a good shipping melon.

Tip Top Musk Melon. The illustration shows a specimen of our strain of this popular melon. This very productive melon is of medium to large size, nearly round, slightly ribbed and fairly well covered with shallow netting. The flesh is deep yellow in color. The universal testimony of ereryone using Tip Top is that every fruit produced, whether big or little, early or late in the season, is a good one-sweet, juicy, finest flavor, m but not hard fleshed, eatable to the very coating.

Delicious Gold Lined. A new melon of fine uniform shape and withont ribs; slightly oval; meat thick, green and light gold towards center.

Honey Dew. The fruits are round or slightly oval, six to eight inches in diameter and weigh about six to eight pounds; the skin is smooth and when ripe is creamy yellow in color; flesh light emerald green, fine grained and of very sweet sugary flavor. Rind thin but very firm and the fruits stand shipping remarkably well. 


\title{
WATER MELON
}

For water melon, follow our cultural directions for cucumbers, except that it is necessary to give the water melon a space of eight to ten feet between hills, and thin the plants to two to the hill. One ounce plants twenty-five hills and three pounds of seed plants an acre.

Cole's Early. Very hardy, a sure cropper and extremely delicate in texture of flesh, which is of dark red color; rind is thin and extremely brittle, hence not desirable for shipping purposes, but possessing all the other most desirable features. We highly recommend it for home use.

Gypsy, or Georgia Rattlesnake. One of the largest varieties and stands shipment long distances. Fruit cylindrical, square at the ends, smooth, distinctly striped bright scarlet and rery sweet.

Peerless or Ico Cream. Medium sized with rery sweet, scarlet flesh. A good variety for main crop.

$\star$ Sweetheart Water Melon. This melon is early, large, handsome, heary and productive. The shape is oral and the color mottled light to a very light green. Flesh bright red, solid, but tender and very sweet.

Florida Favorite. A very large, long melon mottled dark green with stripes of lighter shade. Rind thin but firm; flesh very bright, deep red, very sweet, tender and excellent.

Kolb's Gem. Vines of medium size, but remarkably vigorous and healthy.
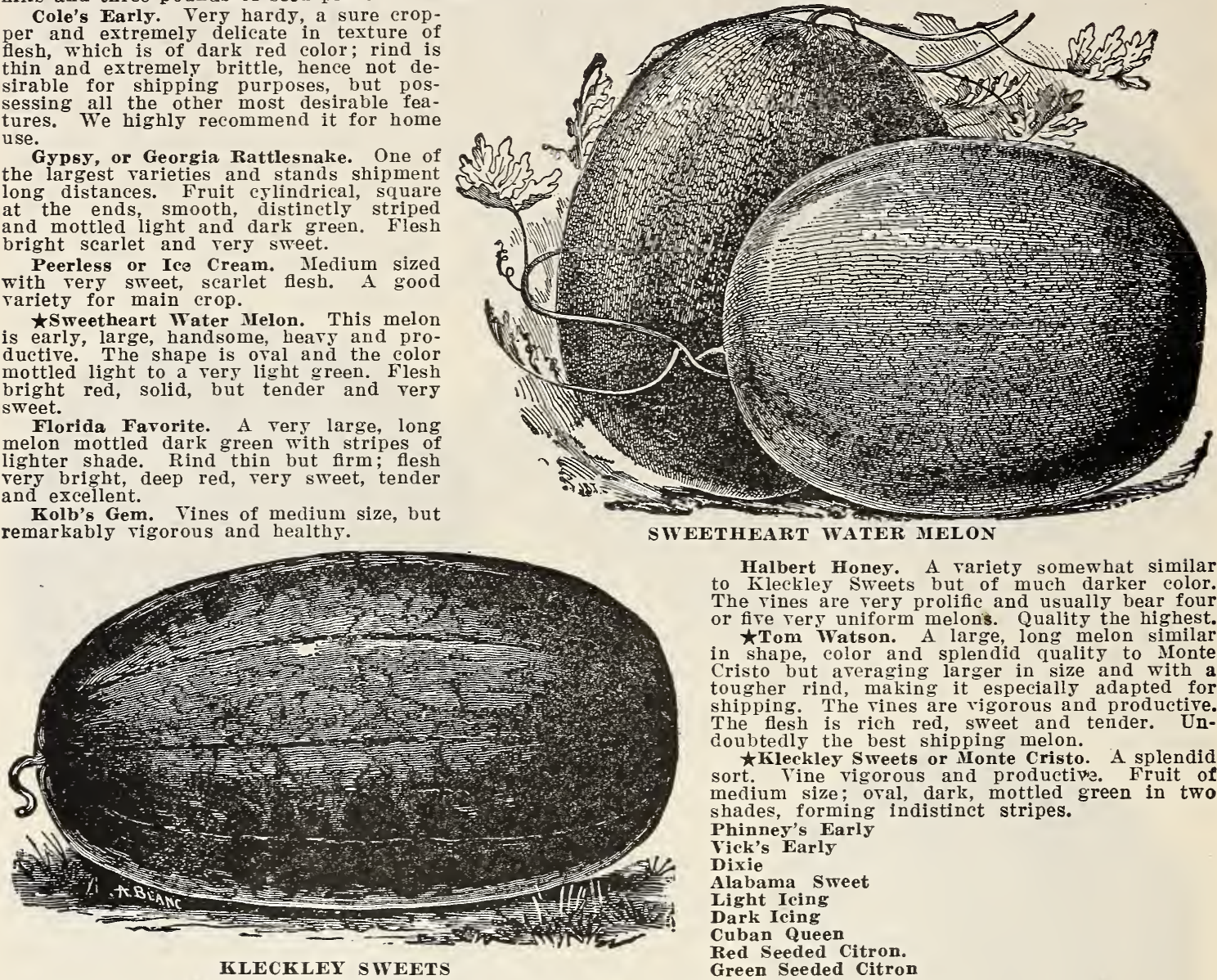

Halbert Honey. A variety somewhat similar to Kleckley Sweets but of much darker color. The vines are very prolific and usually bear four or five very uniform melons. Quality the highest. $\star$ Tom Watson. A large, long melon similar in shape, color and splendid quality to Monte Cristo but averaging larger in size and with a tougher rind, making it especially adapted for shipping. The rines are vigorous and productive. The flesh is rich red, sweet and tender. Undoubtedly the best shipping melon.

$\star$ Kleckley Sweets or Monte Cristo. A splendid sort. Vine vigorous and productivio. Fruit of medium size; oral, dark, mottled green in two shades, forming indistinct stripes.

Phinney's Early

Vick's Early

Dixie

Alabama Sweet

Light Icing

Dark Icing

Cuban Queen

Red Seeded Citron.

Green Seeded Citron

\section{MUSHROOM SPAWN}

For the money invested, no more profitable crop. Once started, it is easy to continue. The supply never equals the demand, so that a market is easily secured.

\author{
Pure Culture, in bricks
}

\section{MUSTARD}

Mustard is grown for its seed, which is used for flavoring or medicinal purposes or grown for its leaf, which is used in salad or cooked like spinach. Sow mustard as soon as the soil can be worked in spring and every three weeks for a succession, or in the south it may be sown in the fall for early spring greens. Cover the seed lightly in twelve to eighteen inch drills. Cut the leaf when not over four inches high and expect this cutting in fifty days from the seeding.

$\star$ Giant Southern Curled. The favorite of the south.

Fordhook Fancy, or Ostrich Plume. Same as abore.

ŁChinese or Large Leaved Mustard. The large leaves which often measure 14 inches, are ready for use in about six weeks after sowing. Plants will continue to yield until frosty weather. Leaves are eaten boiled, like spinach.

Bloomsdale, Large Leaved. Same as the Chinese Mustard described above.

White. Best for general use.

Brown. Stronger than abore.

\section{NASTURTIUM}

Tall Mixed Garden. Grown not only for ornament but the beautiful orange colored flowers and foliage are used for garnishing and the young leaves or shoots are excellent for salads. The green seed pods are greatly esteemed by many for use in mixed pickles.

Dwarf Mixed Garden. Same as above, except that it grows in dwarf form.

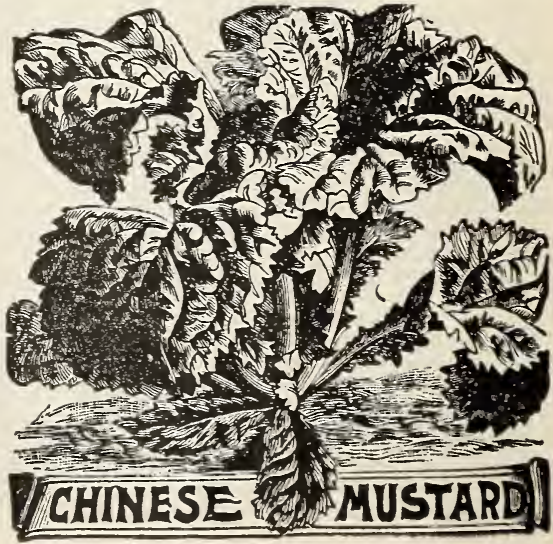




\section{SPECIAL GLOBE ONIONS}

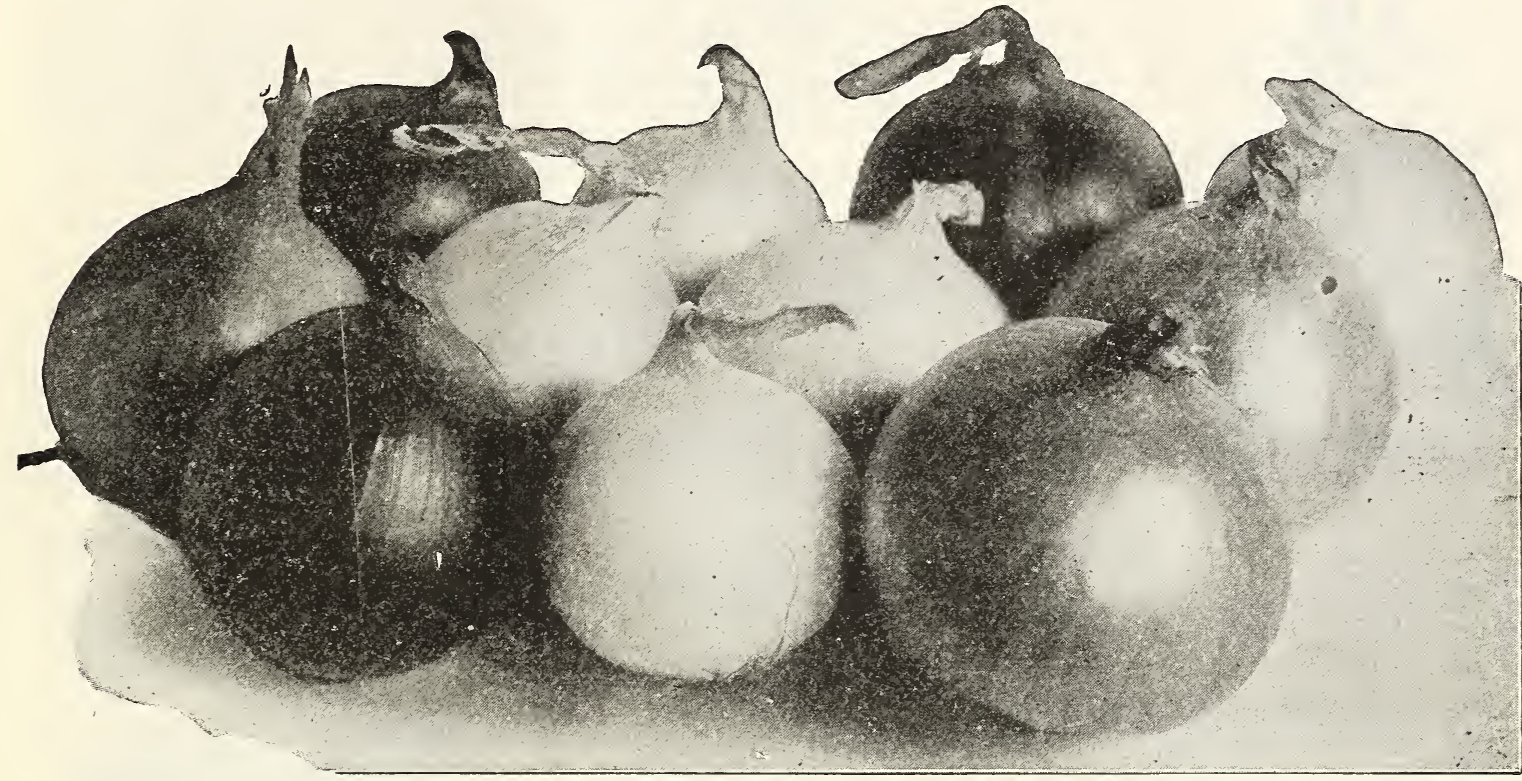

RED GLOBE

WHITE GLOBE

YELLOW GLOBE

Our Three Globes bring more money to the onion grower and sell quicker than any other varieties. Our Yellow Globe is the Standard Yellow, our Red Globe is the Standard Red, and our White Globe is the Standard White.

These stocks are quite superior to the ordinary run of Southport Globes.

$\star$ Red Globe. A fine, large globe-shaped onion, of mild flavor. It is a good keeper, excellent for main crop. *White Globe. A very handsome onion, of splendid quality. Keeps well. It has a good, strong flaror. The best sort for early green onions from seed.

^Yellow Globe. This is a large, handsome yellow variety. Shape, perfectly globular; quality fine. A splendid keeper.

\section{ONION SEED-Standard Sorts}

Study the demands of your market to know what onion that market requires.

As soon as the soil can be worked in spring, and not after May 1st, sow onion seed in twelve to fifteen inch rows, leaving out every tenth row as a weed alley if preferred. One ounce of seed plants one hundred fifty feet and five to six pounds plants the acre. The black slow germinating seed should be covered firnly one-fourth inch deep. Quantities of manure had best be applied in the year before the planting, and much commercial fertilizer, high in potash, harrowed in immediately before seeding.

Begin cultivation as soon as the plant can be seen; cultivate frequently and when convenient thin to a stand of two to four inches.

In the so-called new onion culture, the onions are started in hot beds and easily transplanted when the size of slate pencils to the required stand in the field.

Early Flat Yellow Danvers. A good variety, but not as round or quite as early as the Yellow Globe Danrers.

Yellow Strasburg. or Dutch. One of the oldest varieties. Bulbs quite flat, of good size.

Australian Brown Onion. Is of medium size, wonderfully hard and solid and most attractive for market, both as to form and appearance. The color of the skin is a clear amber brown.

*Yellow Globe Danvers. This fine onion is of large size. An early and abundant cropper. Bulbs very thick, flat or slightly convex bottoms, full oval top with small neck and rich brownish yellow skin.

Michigan Yellow Globe. The bulbs are large and uniformly spherical with very small necks and the largest diameter below the center of the bulbs of a rich orange color.

Ohio Yellow Globe. An early Globe onion, small neck and very uniform in size and color. Very popular in the marsh onion sections of Ohio and Indiana.

Southport Yellow Globe. A large, perfectly shaped Globe onion and an excellent onion for keeping throughout the winter. A very heavy cropper, handsome in appearance and a good dark yellow color.

Prizetaker. Grows to an immense size and for fall marketing is unexcelled. Although of such great size, it is very hardy and a fair winter keeper, as it ripens up hard and firm; very fine grained, and of mild, delicate flavor. The outside skin is rich rellow while the flesh is white. To get the best results from this onion, the seed is sown in beds and transplanted. It will, however, make a good crop if sown in the ordinary way.

$\star$ Large Red Wethersfield. We have a very fine and select strain of this sort. Color is deep purplish red, flesh white, moderately grained and very firm. Ylelds an enormous amount per acre, and is one of the best winter keeping onions.

Southport Red Globe. This is a fine keeper. Large size and considered one of the best red onions. Flesh is fine grained, very mild and tender.

^White Portugal. American Silver Skin. This is the best sort to sow for onion sets or for pickling. When sown

thickly for either it makes a small, round hard bulb.

Philadelphia Silver Skin. Very desirable for family use. Flavor, mild and pleasant.

Southport White Globe. This grows to a very large size and is a perfectly globe-shaped onion. Color is a clear, pure white. This variety is used by market gardeners for bunching.

Bermuda Red. A very early pale red onion, grown extensively in the Bermudas and southern part of the United States for early shipping to northern markets.

White Bermuda. A straw colored onion, mild flavored; yellow in color, otherwise same as red.

Crystal White Wax. This variety is popular in the south where the transplanting method of culture is practiced.

New White Queen is a fine early silver skinned variety, of beautiful form and rapid growth, and possessing fine keeping qualities. 


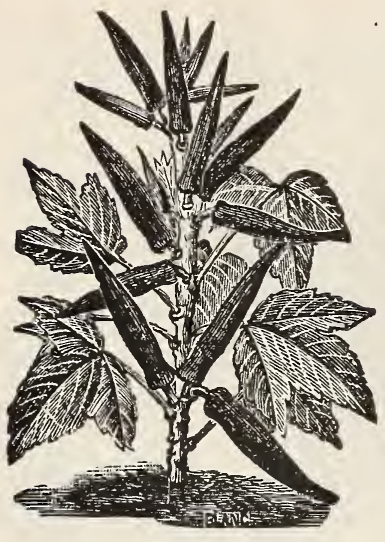

OKRA

\section{OKRA OR GUMBO}

The pods of this plant are used in a great number of ways throughout the Southern States, and the plant should be more frequently grown in the north Plant at corn planting time in rich land, sowing the seed thickly in two or three foot drills, and thinning to an eight to twelve inch stand, according to varieties. A generous planting is two ounces to one hundred feet and ten pounds to the acre. Okra seed may be planted six seed to the hill, two to three feet apart and thinned to two plants to the hill.

Perkins Mammoth Long Pod. The pods are produced in great abundance and average longer than other sorts.

Dwarf Green. Grows low but stocky and is very productive.

Long Green. Taller than above, pods similar.

White Velvet Okra. The pods are perfectly round. smooth and of an attractive white velvet appearance; of superior flavor and tenderness.

\section{PARSNIP}

Plant parsnip seed as early as the soil can be worked in spring and do not cover this slow germinating seed deeper than one-fourth inch. Use eighteen to twentyfour inch rows, thinning the plants to a four inch stand. One-half ounce of seed sows one hundred feet and three to five pounds plants an acre. This crop requires the entire season to mature, and as frost improves the roots, they may be left in the ground all winter. Both as to quantities and its feeding values, the parsnip is a valuable stock feed.

$\star$ Hollow Crown. Roots comparatively short, with a very smooth, clean skin. The variety is easily distinguished by the leaves arising from a depression on the top or crown of the root.

Guernsey. The best sort for heavy, black soils. Where the soil is exceedingly rich this is the variety needed, as it makes a fine shaped root which does not grow too long.

\section{PARSLEY}

Parsley used for garnishing and for seasoning can be planted as soon as the soil can be worked in spring. Cover the slow germinating seed one-fourth inch deep in twelve to eighteen inch rows, later thinning to a six inch stand. One-fourth ounce sows one hundred feet and three to five pounds plants an acre.

Plain or Single. Plain leaves, excellent flavor; very extensively grown for bunching into soup bunches.

Double Curled. The standard sort for outdoor culture, also highly prized by market gardeners for the greenhouse.

$\star$ Champion Moss Curled. A very fine curled variety. One of the handsomest for garnishing purposes. The exceedingly curled leaves make it desirable.

Hamburg Rooted. The standard rooted sort. The leaves are used for soup greens, and the roots, when sliced, are much esteemed.

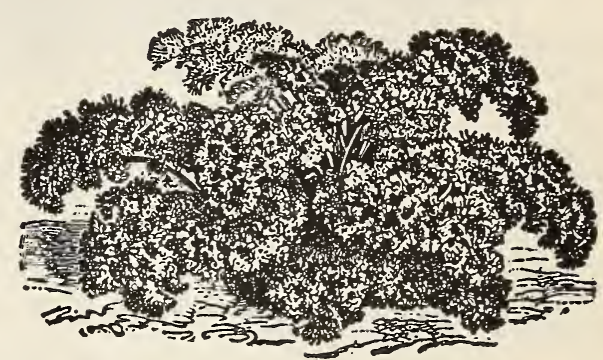

CHAMPION MOSS CURLED

\section{PEPPERS}

The pods of the pepper are used in sauces, salads, soups or as a seasoning, and the large mild varieties called mangoes are eaten from the hand or variously stuffed and prepared with cabbage tomatoes or meat. The pods of peppers are green till in ripening they turn red or yellow, according to the variety.

Start pepper in hot-beds and in other ways treat like a tomato. Set out of doors after frosts in thirty-inch rows, giving each plant eighteen inches in the row. One ounce of seed gives, according to the handling, from one to two thousand plants and one pound plants an acre.

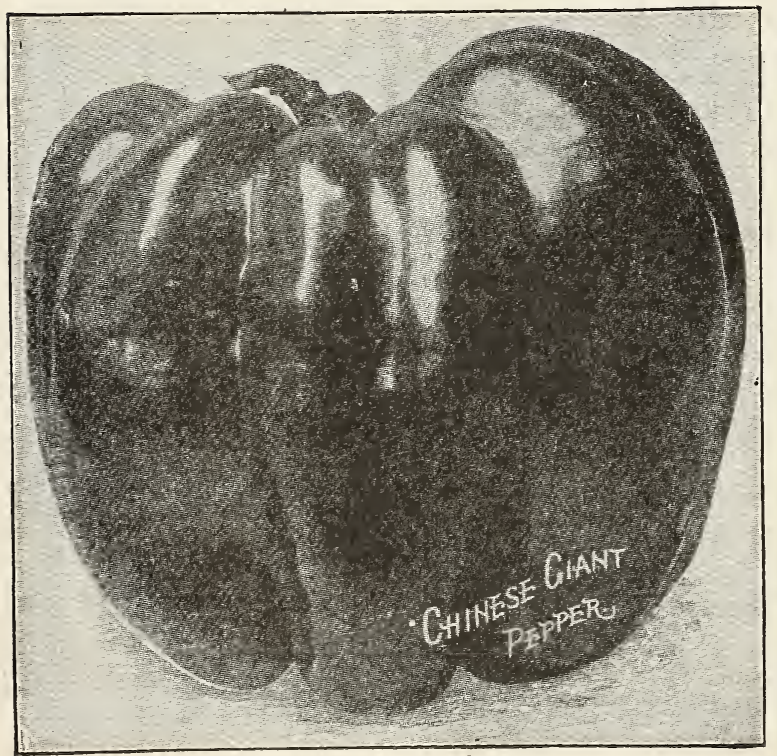

ŁLong Red Cayenne. A long, slim, pointed pod, and when ripe of a bright red color. Extremely strong and pungent.

Red Chili. Used in the manufacture of pepper sauce.

Red Cherry. Plant tall, bearing a profusion of bright red, round fruit which is very pungent when ripe.

Large Bell or Bull Nose. A very large sort of inverted bell shape, suitable for filling or for mixed pickle. Flesh thick, hard and less pungent than most other sorts.

Sweet Mountain. Plants very vigorous and productive, growing upright, with moderately large leaves. Fruit very large, long, often eight inches or more in length, by two in diameter.

†Royal King. A very smooth, sweet pepper, larger than Sweet Mountain, just right for stuffing and pickling.

$\star$ Ruby King. An improved American sort, reaching the largest size, yet retaining the symmetrical shape of the smaller sorts

+Ruby Giant. An improvement over Ruby King. It is larger, smoother, finer grained and sweeter. An excellent pepper.

$\star$ Chinese Giant Pepper. Without doubt one of the very best and largest Mango Peppers ever introduced. Its mammoth size, splendid shape, beautiful, rich, glossyred flesh and mild flavor, all lead us to speak of it in words of commendation.

Pimento. A very thick flesh, heart-shaped, smooth, mild, crimson variety, much used for salads; fruit pendent.

Golden Dawn. In shape it resembles the popular Bell or Bull Nose Pepper. It is of a most beautiful goldep yellow color. 


\section{PEAS}

As to a superiority between smooth and wrinkled peas it is all a matter of individual taste, but the preponderance of taste is in favor of the wrinkled varieties.

ALL VARIETIES OF PEAS, REGARDLESS OF HEIGHT, MAY BE GROWN SUCCESSFULLY WITHOUT A TRELLIS OR SUPPORT. As peas vary in height from six inches to six feet, it follows that the distances in the TRELLIS OR SUPPORT. As peas six inches apart to support and shade each other in their growth; then leave a space of eighteen to thirty inches, according to height of the variety, and repeat the double row. The tall varieties that may be given support are planted in single rows, the space between the rows somewhat less than the height of the variety. Drop ten to twenty dwarf peas to the double row or six to ten tall peas to the foot of row, using one quart to one hundred feet and three bushels to the acre.

Plant all peas at least five inches deep in soil that has been deeply plowed. This deep planting is the grower's attempt to give the peas the cool, damp climate they prefer. Lightly harrow or rake the soil when the peas should be breaking through, and continue to cultivate till the vine stops the work.

All peas stand some frost and may be planted as soon as the soil may be worked in spring. Peas should be planted frequently for a succession all north of the Ohio. The early varieties are planted in August for a late autumn crop.

For quality's sake, pick before they crowd the pod and pick all pods as rapidly as produced to somewhat extend the plants bearing.

As all varieties of peas lose their characteristics when left without that selection given by expert seedsmen, it is necessary to go to a reliable source for seed peas.

\section{SMOOTH SEED}

ŁAlaska. Well known and extensively used, especially by Canners. Very early, and when carefully grown, uniform in ripening. Vine is strong and vigorous, 2 to $2 \frac{1}{2}$ feet high, of a peculiar light green color; pods $2 \frac{1 / 4}{4}$ to $23 / 4$ inches long, straight and blunt at the end, and light in color.

First and Best. Early, productive and hardy, with a strong, vigorous vine, which is light in color and uniform in growth, $2 \frac{1}{2}$ to 3 feet in height and bearing straight pods $2 \frac{1}{2}$ to $23 / 4$ inches long, round, light in color, and blunt at the ends.

Early May Improved. This pea is one of the best of the "White" earlies and is superior to First and Best or Prolific Early Market. Vines are strong growing for this class of pea, about 30 inches in height, foliage pale green. Pods are pale colored, straight, round and blunt. Average 21/4 inches in length. Fit for use fifty-six days from planting. Seed small to medium sized, white and smooth.

Pride of the Market. Of fine growth and general appearance, both vine and pod, and closely resembles the Stratagem except that the vine is not quite so long and the pods are deeper green in color. The vine is 20 inches high, foliage dark green color. Pods are $31 / 2$ inches long, broad and dark in color. Fit for table use sixty-one days from planting. Seed blue, slightly dented, large.

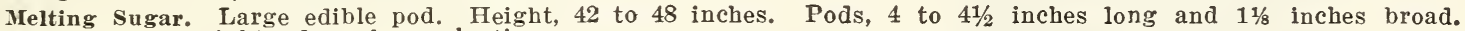
Fit for table use eighty davs from planting.

$\star$ White Marrowfat. Vines hardy, strong, vigorous and bearing broad, thick, leathery pods.

Black-Eyed Marrowfat. Strong and vigorous vines bearing pods near the top of the vine.

\section{WRINKLED SEED}

American Wonder. Vigorous, productive vines, with a luxuriant foliage, and producing the leaves on one side of the stalk, and growing from 9 to 12 inches high. On account of its dwarf habit of growth it is very desirable for private garden use. Pods are light colored, straight, round, about 21/2 inches long, and blunt at the end.

$\star$ Nott's Excelsior. Resembling Gems in habit, but more dwarf and uniform in growth; height, 12 to 17 inches, with rather light foliage.

tLittle Gem. Strong and vigorous in growth, producing vines from 18 to 24 inches in height, dark foliage, bearing pods singly on both sides of the stalk, beginning near the ground. Pods are almost straight, $2 \frac{1}{2}$ to $23 / 4$ inches long, light in color and blunt at the ends.

ŁHorsford's Market Garden. Strongly resembling Premium Gem in habit of growth, but about onethird taller, vines growing 26 to 30 inches high.

Advancer. Vines upright and vigorous in growth, hardy and productive. Height, 30 inches, foliage dark green. Pods $21 / 2$ to $25 / 8$ inches long, round, dark colored and blunt.

$\star$ Laxtonian. Vine $1 \frac{1}{2}$ feet in height with dark green foliage. Large curved aark green pods, pointed at the ends. Seed green, wrinkled, large sized.

tLittle Marvel. Height of vine 18 inches, with dark green foliage. Small blunt dark green pods. Fit for table use fifty-three to fifty-five days from planting. Seed blue green, small sized, wrinkled.

$\star$ Dwarf Telephone. Vines 18 to 20 inches high, with rather coarse foliage, medium light green, bearing pods, broad, straight and about 4 inches long. Pale green in color and well filled with peas of excellent flavor. Ready for picking from sixty-two to sixty-five days from planting. Seed pale green, large, much wrinkled.

Sutton's Excelsior. Similar in habit of growth to Nott's Excelsior, but bearing very large, broad pods, well filled with large peas. Very tender and of the most delicious flavor. Vines about 18 to 20 inches high, medium light in color with pods $3 \frac{1}{4}$ to $31 /$ inches long, light in color and blunt at the ends.

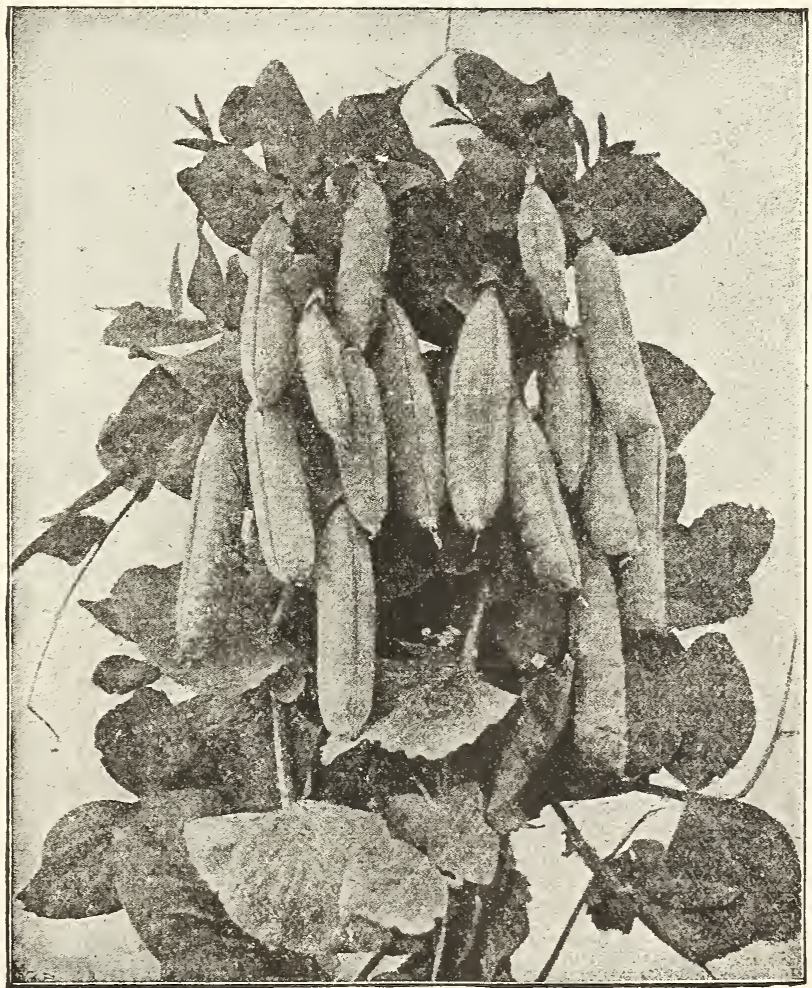

ALASKA PEAS 


\section{PEAS, WRINKLED SEED—Continued}

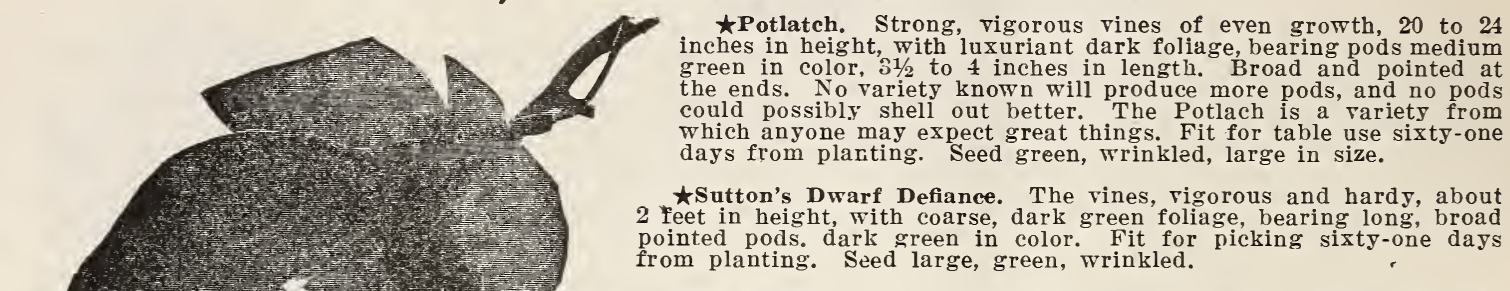

ŁStratagem. A vigorous, hardy and luxuriant vine, bearing large pods cỏntaining peas of excellent quality. A heavy cropper, although it has a tendency to sport. Vines 20 inches. Foliage, dark green. Pods $3 \frac{1}{2}$ inches long, straight, broad, pointed, gray green in color. Fit for table use fifty-six days from planting. Seed very large, green; wrinkled.

$\star$ Gradus. A large, wrinkled, early pea, with a pod nearly as large as Telephone, filled with large peas, tender and of good quality and flavor. Verr quick to germinate and mature with the early sorts. This pea will not stand adverse conditions, howerer, as well as some of the other sorts, and seed must be planted after all danger of early frost has passed. Seed large, cream colored, wrinkled.

$\star$ Thomas Laxton. Closely resembling Gradus in habit, rapidity of growth, earliness and foliage. 26 to 30 inches high, and much hardier in every respect than Gradus.

Admiral Dewey. One of the largest podded pea yet introduced. Height, $3 \frac{1}{2}$ feet; pods a rich, dark green color, frequently 6 inches long, beautifully shaped. Peas large, tender and of first class flavor.

$\star$ Telephone. Vines and leaves large and coarse. Foliage light green in color. Height, 40 to 50 inches; pods, $41 / 2$ inches long, broad pointed, medium green in color. Fit to pick sixty-two to sixty-five days from planting. Seed large, green, wrinkled.

ŁAlderman. A large podded pea of the Telephone type, very robust and vigorous as to vine, foliage, mixed, medium green.

Duke of Albany. Resembling the Telephone in appearance. Vine and foliage medium green in color. Height, 50 inches.

Everbearing. Vigorous and branching in habit of growth. Height, 21/ to 3 feet. Pods, 23 to 3 inches long. Broad, light colored and blunt. Fit to pick seventy days from planting. Seed green, wrinkled, large in size.

Champion of England. Strong and vigorous in growth, 42 to 50 inches in height.

tYorkshire Hero. Hardy, productive, and upright in growth. bearing near the top of stalk, broad pointed pods with peas of a good bearing near the top of stalk, broad pointed pods with peas of a good 3 inches long, blunt, light green in color.

POTLATCh

\section{PUMPKIN}

The finer varieties of pumpkins are used for pies and the coarser ones for stock feeding. While the pumpkin mas be grown very'much as cucumbers are grown in a garden, they are more frequently planted in the field with corn, where several seed are dropped in each fourth hill. Planted alone, six to ten seeds are corered one inch deep in hills eight to ten feet apart and thinned to two to four plants to the hill. One ounce plants twenty-five hills and two to four pounds of seed generously plants an acre. As this crop requires as much time as corn to mature, the planting cannot be too long delayed.

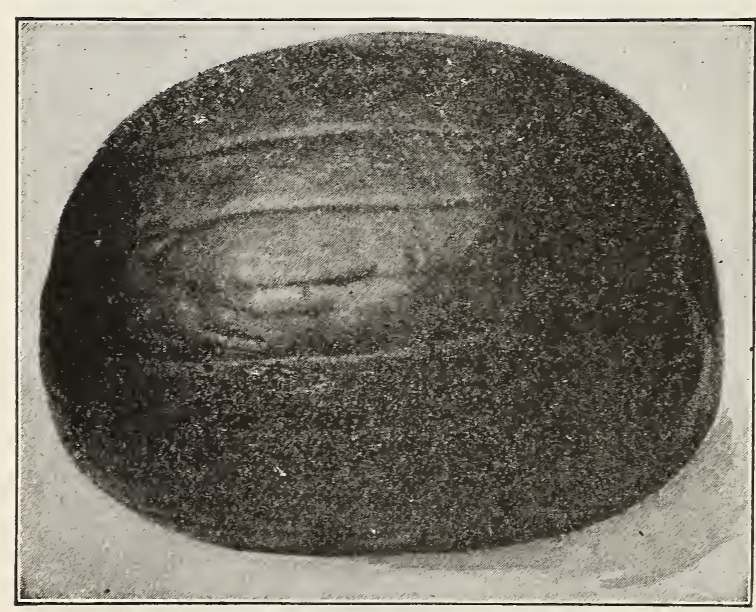

CONNECTICUT FIELD PUMPKIN
Small Sugar. This variety is very small, but of most excellent quality for pies.

Japanese Pie. Shaped somewhat like the Cushaws and grows to a large size; skin deep green with dark stripes; flesh deep yellow and of high quality; seeds sculptured like Chinese letters.

tCheese or Kentucky Field. One of the best for table use, and very productive. Shape flat; flesh yellow, thick and tender.

Connecticut Field. The hardiest of all pumpkins cultivated mainly for stock-feeding, producing enormous crops.

Mammoth Potiron. The flesh and skins are of a bright golden yellow color. Flesh fine grained and of excellent quality. This enormous variety has been grown to weigh 200 pounds.

Winter Queen. This is an improrement of the old well-liked sugar pumpkin. Its size is uniformly about nine to ten inches in diameter, color, a beautiful deep orange vellow, with a close netting, almost as russeted as a potato.

$\star$ Pie. Fruit of medium size, nearly round; skin light zellow, smooth and covered with a fine gray netting. Flesh light yellow, very thick, sweet and finely flavored. Mlakes very delicious pies.

Tennessee Sweet Potato. Hardy, productive, sweet and delicious, and one of the best for cooking purposes ever introduced. 


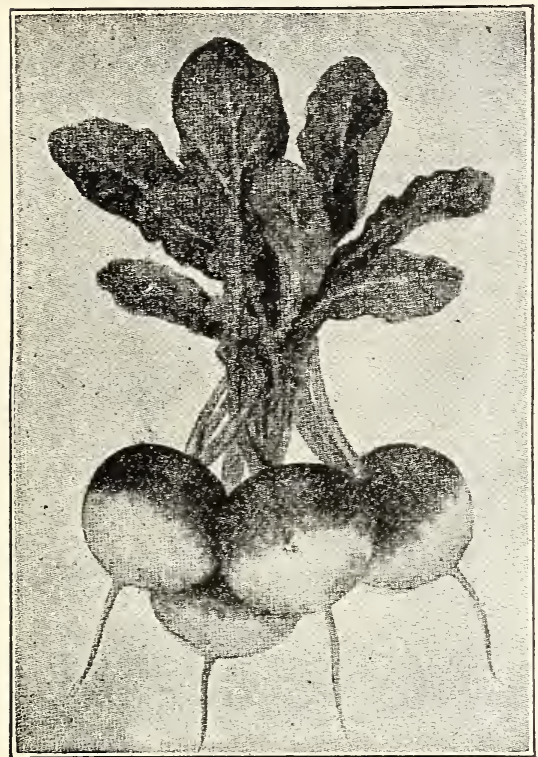

SCARLET TURNIP WHITE TIPPED RADISH

\section{RADISH}

Plant radishes on a light soil if a choice is possible, and every second week for a succession from the time the soil can be worked in spring till the first light frost. Plant in ten to eighteen-inch rows, cover the seeds one-half inch deep and permit four to ten radishes to grow to the foot of row, according to variety. Use one ounce of seed to one hundred feet of row and eight to twelve pounds to the acre. Radish seed, which germinate quickly, may be sown with some slow-germinating seed that the cultivation of that crop may begin the earlier, or the quicker-growing radish may be grown between rows of some slow-growing crop that later requires considerable space. The Winter Radish is sown at late turnip planting time and used in the autumn or stored for winter like the turnip.

tEarly Scarlet Globe. A desirable sort for hotbed forcing and outdoors very early : flavor mild, crisp, juicy and tender; top small; will stand heat without becoming pithy. One of the best selling and most attractive radishes on account of its bright scarlet color and handsome shape. Is ready in twenty-eight days. nip, Forcing. A variety extraordinary in that, while growing to an unusually large size, it is always tender, crisp and of mild flavor. It remains in perfect condition a remarkably long time, and unlike other forcing varieties, does not become pithy even when twice their size in diameter.

$\star$ Long Scarlet, Short Top Improved. This bright scarlet, small topped sort is about six inches long.

The Cincinnati Market. The tops of this new radish are ver small and may stand much closer in rows than Wood's Early Frame or Long Scarlet, without danger of running to seed.

\White Icicle. This handsome white variety is becoming very popular. It is similar to White Vienna, but is not so long, is earlier and has a shorter leaf. We recommend it as a profitable, early variety where a long white sort is desired.

Early Scarlet Turnip. The standard early turnip radish. Fine flavored and mild.

$\star$ Scarlet Turnip, White Tipped. One of the handsomest of the turnip radishes and a great favorite in many large markets, for early planting outdoors.

$\star$ French Beakfast. Olive-shaped, scarlet, with white tip; crisp and tender. Very early. A general favorite.

Early White Turnip Rooted. A little flatter than the Scarlet Turnip, and pure white in color.

Long Brightest Scarlet, White Tipped. This is the brightest and handsomest colored scarlet radish known.

Chartier. Decidedly distinct in appearance from any radish in cultivation.

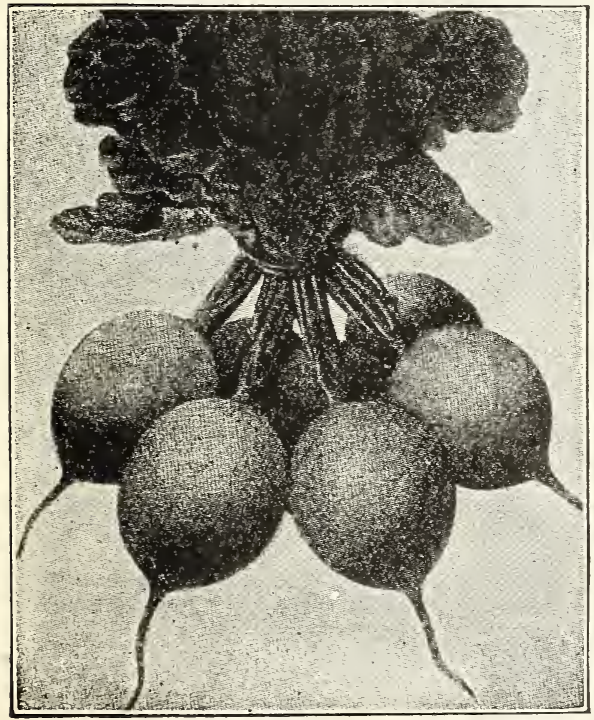

SCARLET GLOBE RADISH
Crimson Giant Tur-

Long White Vienna, or Lady Finger. A very excellent white variety with long, very smooth white roots.

White Strasburg, or Summer Hospital. Large, show y, half long, white sort.

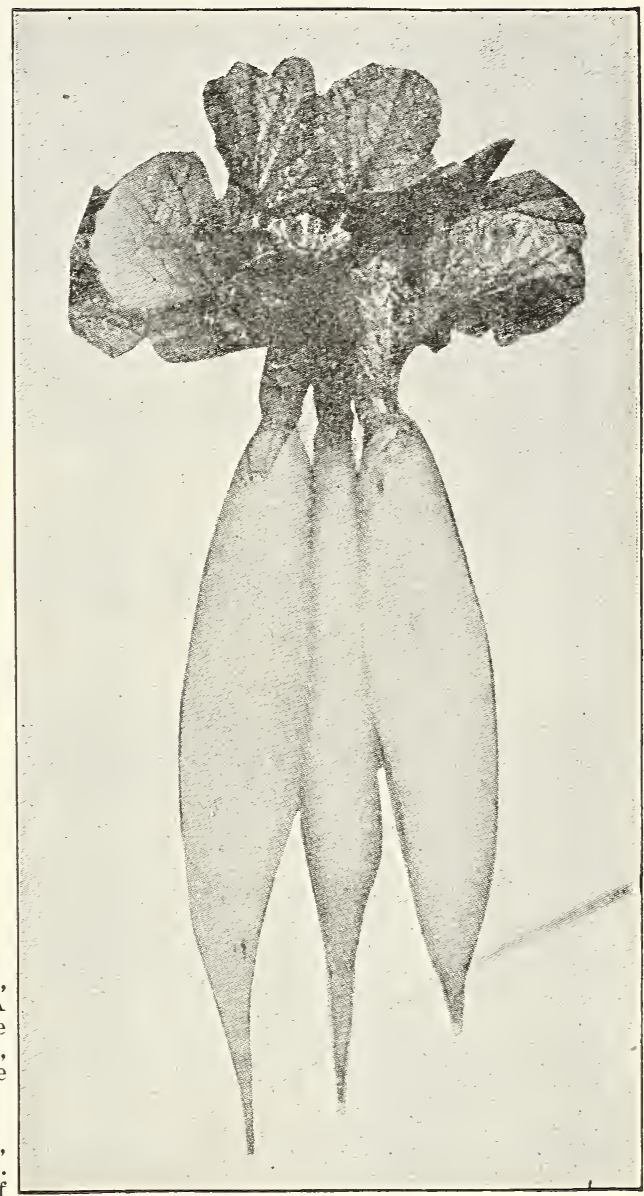

WHITE ICICLE RADISH
White Summer Turnip. A very large turnip-shaped variety; white, very crisp and mild.

Giant Stuttgart. A summer variety. Grows to a large size. White flesh, very crisp and tender. Of good flavor and a good keeper.

\section{RADISH - WINTER VARIETIES}

$\star$ Rose or Scarlet China. Roots cylindrical, or largest at the bottom, tapering abruptly to a small tap. Skin very smooth and of a bright rose color.

* White China or Celestial. A comparatively new variety which is popular wherever known. The root is long, cylindrical, with beautiful white skin.

California Mammoth. First introduced into this country by the Chinese in California. It is pure white. The flesh is tender and crisp, keeping well through the winter.

Large White Spanish. A large rooted winter variety.

Round Black Spanish. Roots round, sometimes top-shaped, 3 to 4 inches in diameter; skin black, flesh white.

$\star$ Long Black Spanish. One of the latest as well as hardiest of the radishes; an excellent sort for winter use. 


\section{RHUBARB}

Rhubarb, familiarly known as Pie Plant, or Wine Plant, is cultivated in gardens for its leaf stalks, which are used for pies and tarts. Immense quantities are now annually sold in all the larger markets. No private garden
should be without it.

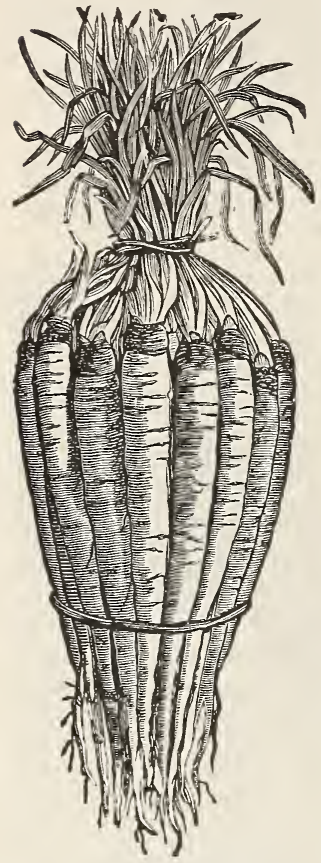

LARGE WHITE SALSIFY

Rhubarb succeeds best in deep, somewhat retentive soil. The richer its condition and the deeper it is stirred the better. Sow in drills an inch deep, and thin out the plants to six inches apart. In the fall transplant the young plants into very highly manured and deeply stirred soil, setting them four to six feet apart each way, and give a dressing of coarse manure every spring. The stalks should not be plucked until the second year, and the plant never allowed to exhaust itself by running to seed. Our seed is saved from selected plants of the Linnaeus, Victoria, Giant and other improved sorts, but like the seeds of fruit trees, rhubarb seed cannot be relied upon to reproduce the same varieties.

Rhubarb Seed.

Rhubarb Roots.

PRICES ON LARGE LOTS OF RHUBARB ROOTS ON APPLICATION.

\section{SALSIFY \\ (VEGETABLE OYSTER)}

The long, white tapering root of salsify resembles a small parsnip, and when cooked is a good substitute for oysters, having a very similar flavor.

It succeeds best in a light, well-enriched soil, which should be stirred to a good depth. Coarse and fresh manure should be avoided, as it will surely cause the roots to grow unevenly and ill-shaped. Sow early and quite deep, giving the general culture recommended for parsnip. The roots are perfectly hardy, and may remain out all winter, but should be dug early in spring, as they deteriorate rapidly, after growth commences. Store a quantity for winter use in a pit or cellar in damp earth or sand.

Large White. The common variety, roots medium sized, smooth; flesh white.

Mammoth Sandwich Island. This is in every way superior to the Large White, being larger, stronger growing and less liable to branch. Invaluable to market gardeners.

\section{SORREL}

Large Leaved French. Sow in drills as soon as the soil can be worked in spring and three to six inches apart in the row. Cutting begins in sixty days and continues for several years. Used as cooked "greens" or as a salad.

\section{SPINACH}

Spinach, a delicious green, resembling in growth a non-heading lettuce, is happily the best of tonics. As early as the soil can be worked, sow it one-half inch deep in fourteen-inch rows, using one ounce of seed to one hundred feet, and in the second week will appear a tiny plant with two rery narrow leares that do not resemble the true leaves that follow. Cutting should begin forts-five days from sowing. It is impossible to put spinach on too rich a soil, and nitrate of soda is used on it with profit.

South of the Ohio, spinach winters without protection. North it very often winter kills with good drainage and the best of straw covering.

All spinach quickly runs to seed in the heat of summer.

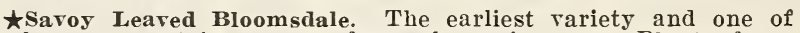
the best to plant in autumn for early spring use. Plant of upright growth, with narrow, pointed leares, which are curled like those of the Savoy cabbage. It grows quickly to a suitable size for use, but soon runs to seed.

Improved Thick Leaved. A variety which grows very rapidly, forming a cluster of large, very thick, slightly wrinkled leares of fine color and quality when cooked. Especially recommended for market gardeners.

Round Leaved. This variety is generally preferred in the North for early spring sowing, and is the favorite with our market gardeners. The leaves are large, thick and fleshy. Though not quite as hardy as the Prickly Winter, it stands the winter very well.

Fill Basket. The largest early spinach, its broad, thick, dark green leaves are very tender and of delicious flavor. Withstands hot weather well.

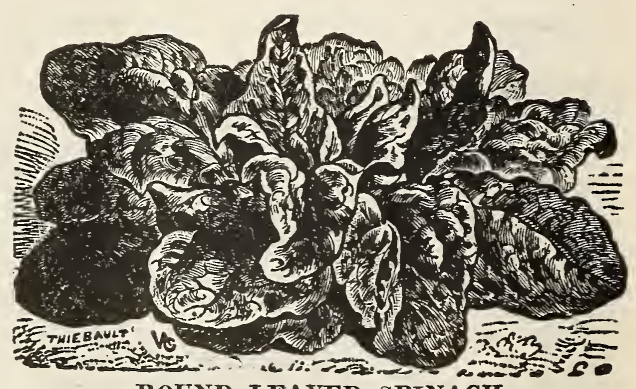

ROUND LEAVED SPINACH

Long Standing. An improved, round seeded strain of excellent merit, having all the good qualities of other sorts and continuing in condition for use much longer. The leaves are smooth and very dark, rich green. Very popular with market gardeners.

Victoria. An excellent sort, which forms a very large, exceedingly thick, dark green leaf somewhat curled in the center. It becomes fit for use nearly as early as any, remaining so much longer than most kinds, and cannot fail to please, whether grown for the market or in the private garden.

Prickly Winter. A very hardy variety and will withstand the severest weather with only a slight protection of leares or straw. The seed is prickly. leaves triangular, oblong or arrow shaped. It is used for fall sowing, which in this latitude is about the first of September.

New Zealand. (Tetragonia expansia.). This branching plant, a spinach in its use and not in its growth. frost kills, but grows luvuriantly in the summer heat. Plant these large seeds three in a hill, three by two feet apart or start the plants under glass and transplant.

Prices of Seeds Vary. We quote Market Values upon request and always give our customers the benefit of the lowest price that the market conditions will warrant. Special prices on a general list will be given upon application. LET US HEAR FROM YOU. 


\section{SQUASH}

The directions for the planting of cucumbers can be followed with slight modifications for squash or cymling. Plant the summer squash in hills four feet apart and use before mature. Plant the winter squash in hills six or eight feet apart; handle without bruising and store in a dry, moderately warm place for winter. Plant the seed generously and thin to swo or three plants to a hill. One ounce of seed plants twenty-five hills and two to four pounds plants an acre. The squash is to be recommended either for the table or the feed lot.

Straight-Neck Summer Squash. Market gardeners who ship early squash to distant markets know the difficulty of packing the crook-necked variety in boxes to good adrantage. In our straight-neck the bad feature of the crook has been orercome, and by continued selection the size has been increased more uniformly in shape and improved quality.

Giant Crook-Neck. This strain is a great im. provement on the old rariety of Crook-Neck. It is larger and better in every way.

$\star$ Summer Crook-Neck. A standard, early and productive summer sort, truits about a foot long, moderately warted and of a bright yellow color.

Mammoth White Bush. This has keen obtained by rears of careful selection. Although we have sold this squash for a number of vears, we again call special attention to it.

$\star$ Early White Bush Scallop. Similar in form to the Golden Bush but with a cream white skin, and more tender and delicate flesh.

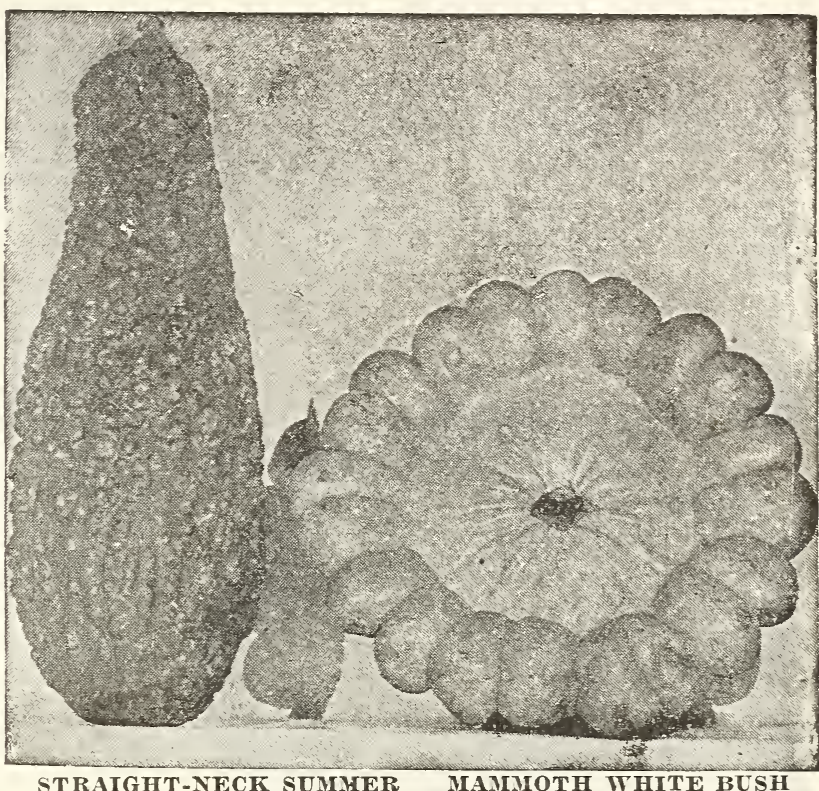

STRAIGHT-NECK SUMMER

MAMMOTH WHITE BUSH

\Warty Hubbard. This is the best strain of Hubbard Squash. By its rough, hard, warty shell and its dark olive green color it can be distinguished from any other strain, either in the field or on the market. It was introduced in 1894 and since that time under different names at different places it has been giren out to all who hare called for the best stock of Hubbard Squash. We have maintained its purity by continued selection and offer headquarters seed.

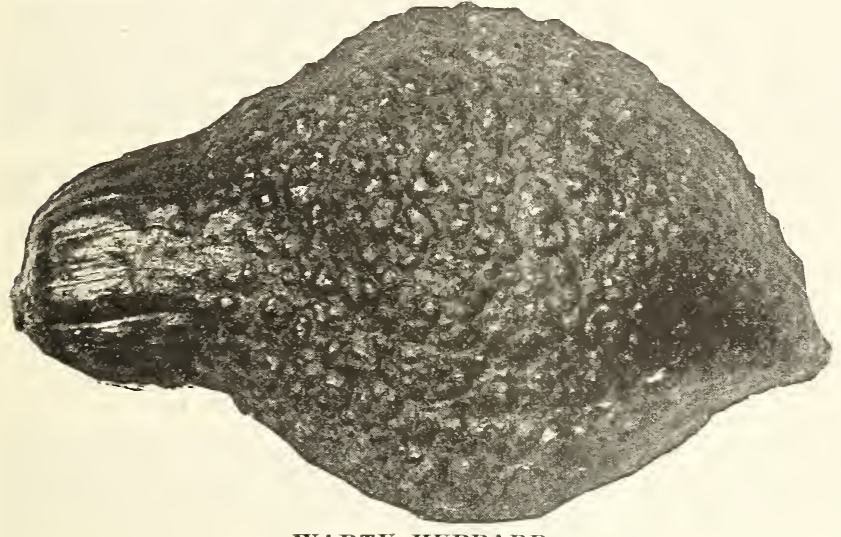

Hubbard. A general favorite and more largely grown as a late sort than any other; it is of large size, often weighing from. nine to ten pounds. Color bluish green, occasionally marked with color blu or dry, and of excellent flavor. It can be had in use from September to May.

Red or Golden Hubbard. This is a rery dis. tinct sort, of the shape and general character of the Hubbard, but a little smaller; of rich orange red color, instead of the dark olice green.

Boston Marrow. Second early, coming in about ten dars after the bush and crook-neck sorts. Skin yellowish, very thin; the flesh dry and fine grained and of unsurpassed flavor.

Essex Hybrid. This is not only one of the richest flarored, finest grain and sweetest of all squashes, but it is also one of the rery best keepers that we know of. Short cylindrical shape, ers blossom end a small cap shaped enhargement. The flesh is dry, sweet and thick, and of a bright orange color.

Jammoth Chili. The largest of all squashes, growing to an immense size, often weighing over 200 pounds, while its rich tine-flarored flesh insures

WARTY HUBBARD its ralue for all purposes.

Fordhook. The vines are of strong, vigorous growth and wonderfully productive. Fruits oblong in form, eight to ten inches in length. slightly ridged; smooth, thin, yellowish skin; flesh very thick and of a light straw yellow.

Delicious. This is one of the best winter varieties. Its color is almost uniform of a green shade, with occasionally a blue specimen, it being just about as pure in this respect as was the original Hubbard. In size it also closely follows the original Hubbard, which weighed between fire and ten pounds. In thickness of flesh it surpasses nearly every variety, the color being a dark orange.

Delicata. Early and very prolific; of oblong shape. Ground color orange yellow, splashed and striped with rery dark green. Although of small size, the squashes are very solid and heary, while the quality is rich and'dry.

\section{SWISS CHARD}

(See Page 4)

\section{TOBACCO}

Connecticut Seed Leaf. The best sort for cigar wrappers. Try it.

Havana. This is the genuine article, and is first class.

White Burley. A favorite for plug fillers and wrappers.

Yellow Pryor. A fine yellow sort, and succeds well where others fail. CONNECTICUT SEFD LEAF TOBACCO

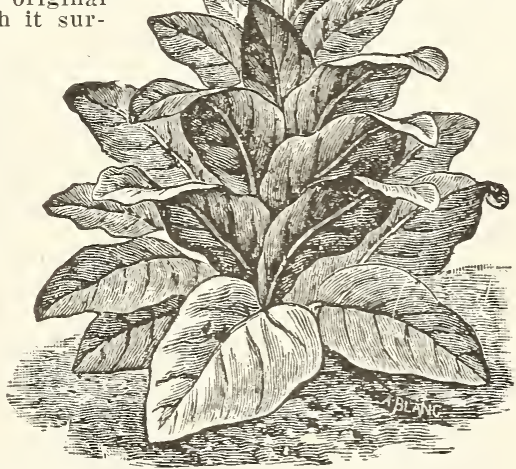




\section{TOMATO}

The tomato requires one hundred days or more to mature from seed. As tomatoes are killed by other than light frost, early tomatoes should be started in hot beds two months before they may be transplanted out of doors. Three weeks later these plants may be potted or given a space of four by four inches in the hot beds. Before setting in the field, which is May north of the Ohio, the plants should be gradually exposed to the outside conditions and the quantity of water given them decreased. Transplant on a cloudy day if possible, and water freely. Nitrate of soda may be given each plant at this time with profit.

A space of four by four feet should be given each plant in the field or more for robust varieties, except that where they are carefully pruned and trained, which is unnecessary, they may be planted as close at two by two feet. One ounce of seed gives two thousand plants.

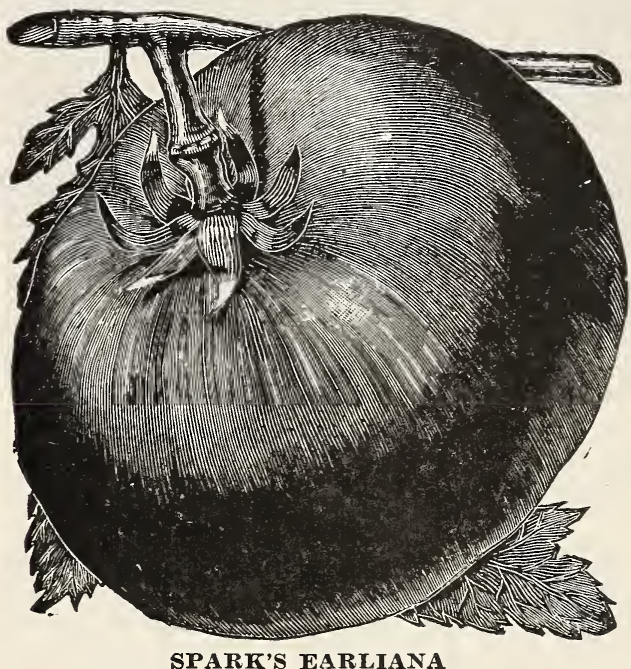

$\star$ Spark's Earliana. Said to be the earliest large tomato in the world. This tomato is not only remarkable for its earliness, but for its very large size, handsome shape and bright; red color. Its solidity and fine quality are quite equal to the best medium and late sorts. From less than four thousand hills the originator realized from his first pickings $\$ 725.00$ clear of freight and commission, being in the market fully a week before all others.

$\star C h a l k ' s$ Early Jewel.. The largest, smoothest and finest flavored early tomato in cultivation. Within a week to ten days as early as the famous Spark's Earliana. Fruit rich deep scarlet.

John Baer. An early, productive, red tomato on the order of Chalk's Early Jewel.

Early Detroit. A very fine, early, large-fruited purple variety ; a little larger than Beauty and somewhat earlier; fruits globe shaped, smooth and solid.

Crines June Pink. A fine new variety. It is highly recom mended to gardeners whose trade demands the purplish pink sort.

Acme. One of the best standard sorts. Of a fine crimson purplish color. Shape is smooth, size large and uniform. For the market or home garden no sort is better.

ŁBeauty. A decided favorite for either home market or shipping purposes, being early, hardy, a strong grower, productive, large size, always smooth, perfect in shave, and excellent in quality. The color is a very glossy crimson with a tinge of purple. It grows in clusters of four to six large fruit, retaining its large size late in the season. It ripens with Acme and Perfection, and is entirely free from ribbed and elongated fruit.

Trucker's Favorite. The finest large-fruited purple tomato. The fruits continue of large size to the very last and are always unexcelled for slicing or cooking.

Livingston's Favorite. A well known red variety, smooth and solid.

Perfection. A splendid red variety, hardy, productive and a good bearer.

Paragon. The well known staudard bright red tomato.

Matchless. A good canning and all purpose tomato, splendid for kitchen.

$\star$ New Stone. A fine new, red variety, very solid and smooth; a splendid main crop sort.

Greater Baltimore. A splendid variety for canning, similar to Stone.

Red Rock. An extraordinarily solid, smooth, very red tomato; a very heavy producer, of excellent shape and very superior texture and flavor. An excellent variety for truckers and canning factories on account of its shape, quality and productiveness. This tomato is very free from cracks, has a very shallow stem attachment and is practically smooth. Fruits will probably average from eight to nine ounces. Borne in clusters of from four to seven fruits, and ripens in 110 days from sowing of seed.

Livingston's New Globe. Is of beautiful globe shape, with quite a percentage of elongated fruits which permit of a greater number of slices being taken than with flat fruited sorts.

Dwarf Champion. This is a purple fruited variets, whish forms very strong plants about two feet high. The branches are short, making a bushy plant that stands quite erect without stakes. This sort is often sold as Tree Tomato. Fruit smooth, medium sized, color purplish pink, fairly solid, but has no hard core, and is of good flavor. About as early as any purple fruited tomato, and is quite popular in some localities, both for market and home use.

+Ponderosa. This variety, when conditions are favorable, grows to an immense size and makes the heaviest fruit of any in the list. Our stock is from the original strain. None better.

Crimson Cushion. A large fruited variety; smooth on top but inclined to curve at the ends, making an indenture at the stem. Color a glossy crimson tinged pink. Fruit ripens evenly, except toward the stem, where it ripens somewhat slowly. A very solid heavy tomato.

Yellow Pear. Pear shaped; yellow.

Yellow Plum. Plum shaped; yellow.

Yellow Peach. Same as the red peach except color.

Golden Queen. Fruit large and smooth; color a beautiful golden yellow, sometimes with a slight blush of red, as smooth and well shaped as the best of the red varieties and of superior flavor.

Husk, or Ground Cherry. This is a small sized fruit grown within a husk. It is valuable for preserving and making into pies', or for eating from the hand.

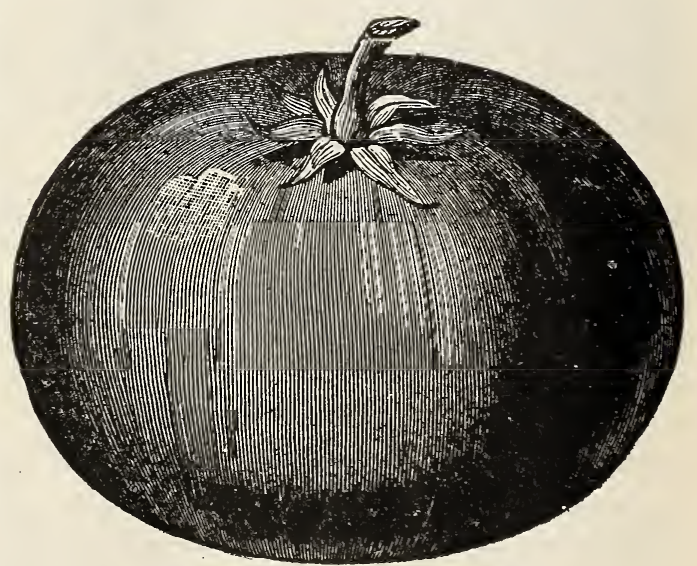




\section{TURNIP}

While the main crop of turnips is planted in July north of the Ohio, more turnips should be grown in early spring. Seed may be broadcast on the few soils freed of weeds, but it is more advisable to sow in one or two-foot drills, cover less than one-half inch and thin to stand six inches apart in the row. Use one-half ounce of seed to one hundred feet of row and two pounds to the acre. The turnip requires one-half more seed when broadeast than in drills and the salad turnip requires one-half more seed than the turnip sown for a root crop.

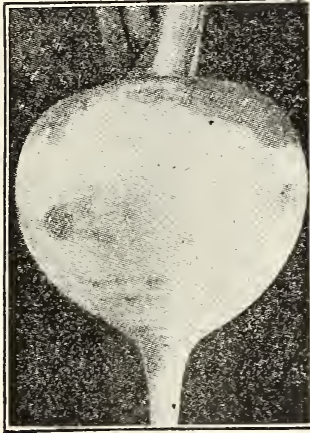

Extra Early White Milan Turnip. The Early White Vilan is one of our most popular turnips for spring sowing, a splendid extra early turnip in which the extreme earliness, small top and tap root of the Purple Top Milan is united with clear white skin and flesh.

Extra Early Purple Top Milan. The earliest in cultivation, two weeks earlier than Purple Top Strap Leaf. The bulb is flat, of medium size, quite smooth, with a purple top. Flesh, white, hard and of finest quality. It is an extra good keeper.

$\star$ Early Snowball. A perfectly globe-shaped, white-skinned turnip. It is exceedingly productive. The flesh is fine grained, firm and of very delicate fiavor. It is one of the best keeping of the white-fleshed sorts. Very early and particularly adapted for family or market use. We recommend it to market gardeners because its earliness and fine appearance make it a very profitable variety of turnip.

Early White Flat Dutch. An excellent garden variety. The best for spring sowing.

$\star$ Purple Top Strap Leaf. Rapid grower and mild flavor. The most popular variety for early use, either for the table or stock.

ŁPurple Top White Globe. An early variety. Globe shaped; heavy cropper. In other respects similar to the Red Top Strap Leaf. A handsome looking bulb. And is rapidly taking the lead of all other varieties of early turnips for market garden purposes.

Cow Horn. This variety is pure white, except a little shade of green at the top, and is carrot-like in form. growing nearly half out of the ground, and slightly crooked. It is FURPLE TOP GLOBE delicate and well flavored, of very rapid growth, and has obtained considerable favor as a market sort for fall and early winter use.

Large White Norfolk. The standard variety for field culture for feeding stock. Very large size.

White Egg. Belongs to the class of quick growing fall turnips. Its shape is nearly oval or egg, as its name would indicate.

$\star$ Pomeranean White Globe. This is one of the most productive kinds, and in good, rich soil roots will frequently grow to twelve pounds in weight. It is of perfect globe shape; skin white and smooth; leaves large and dark green.

Seven Top. Cultivated extensively in the South for the tops, which are used for greens. It is very hardy and will grow all winter, but does not produce a good root, and is only recommended for the tops.

Golden Ball. Undoubtedly among the most delicate and sweetest yellow fleshed turnips zet introduced. Not of a large size, but firm, hard and of most excellent flavor. Keeps well and is superior as a table variety. It is extensively used.

Yellow Aberdeen. Very hardy and productive; a good keeper; globe shaped. Color pale yellow with purple top. Very firm in texture, and closely resembling the rutabaga in good keeping qualities. Good eituer for table or stock.

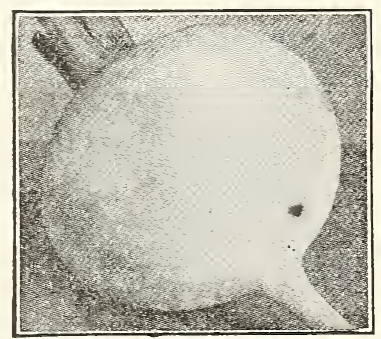

EARLY SNOWBALL

ત Amber Globe. One of the best varieties for a field crop for stock. Flesh yellow, fine grained and sweet; color of skin, yellow; top green. Hardy, keeps well, a good cropper. Very popular in the South.

\section{RUTABAGA}

Rutabagas, or Swedish Turnips, with their superior keeping qualities had best be drilled a month earlier than other turnips, given eighteen to thirty-inch rows and thinned to stand six to twelve inches apart in the row.

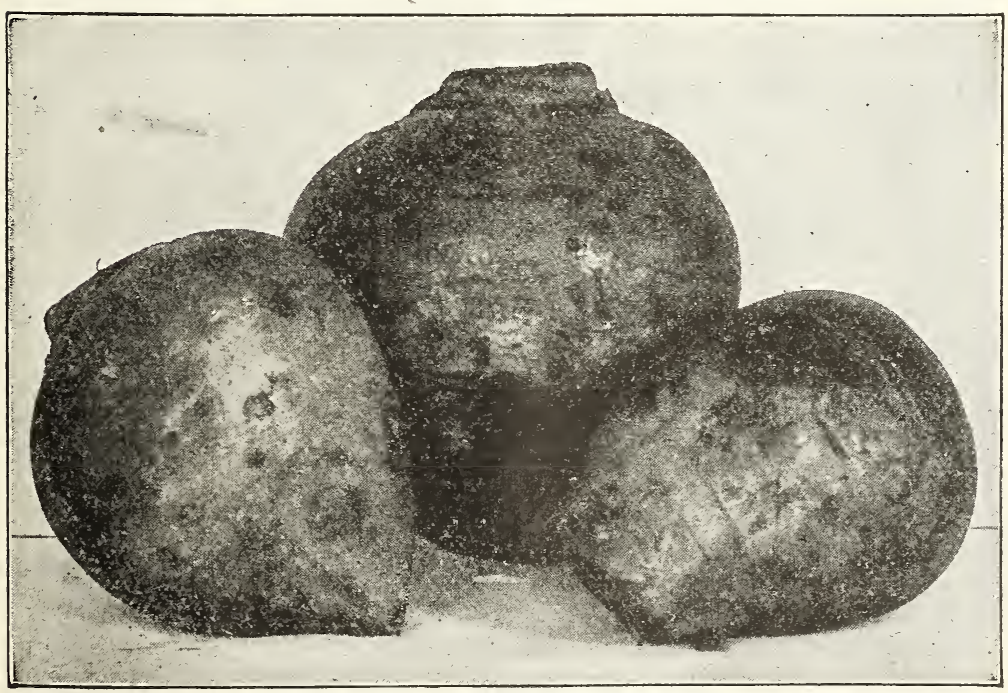

MMPROVED AMERICAN RUTABAGA

$\star$ Improved American Purple Top. The best yellow fleshed, purple top variety grown for stock or table. I.aing's Improved. One of the earliest of the rutabagas. Forms a handsome bulb of good quality. Keeps well; good for table use.

Carter's Imperial Purple Top. An English variety resembling the preceding. Very productive and of fine quality.

$\star$ White Rutabaga. This variety now extensively cultivated, and preferred in many sections for its white fiesh. It is very hardy and productive, keeps well until late in the spring, and is highly esteemed for its sweet, delicate flavor.

Monarch or Tankard. This is a yellow fleshed sort having very large tankard shaped roots, with relatively small necks and tops. Color purplish crimson above ground, yellow below; flesh very solid, fine grained and of the best flavor. This very popular variety is also sold as Hurst's Monarch and Carter's Elephant.

Budlong's White Rock. Though sometimes called a turnip, this is more like a rutabaga. The root is large, both skin and flesh very desirable sort for market gardeners.

Sweet German. A superior variety for table or stock. Flesh firm, sweet and juicy.

Bangholm. A very superior variety, both in form and quality, and held in high estimation in many parts of

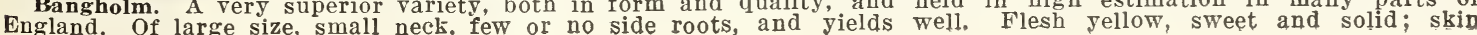
yellow with purple top. 


\section{NASTURTIUM}

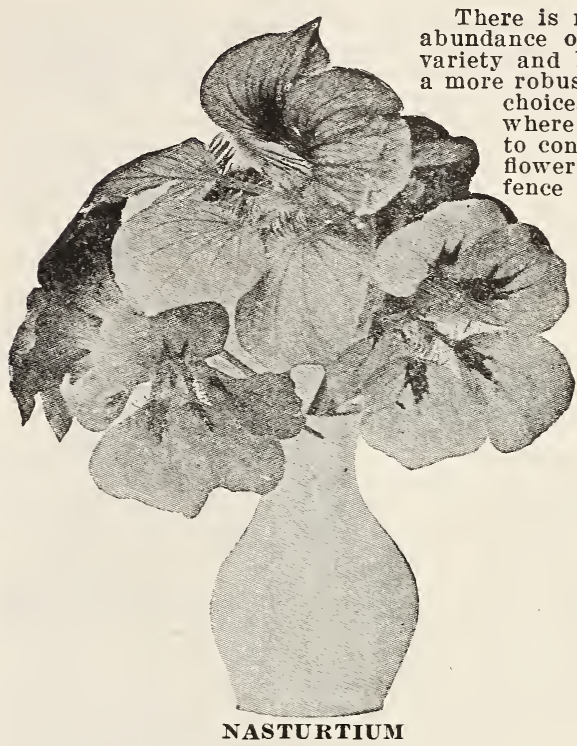

is no plant that in so short a time at so little expense will give such an of bloom, continue that blooming over so long a period and give such and brilliancy of color as the nasturtium. On a rich soil this plant gives us robust growth and fewer flowers, so the thinner soil is to be used if there is a the plant is to grow and remember to pick the the seed one inch deep ontinue the is to grow and remember to pick the seed balls as they form fower but is most frequently used as a tapestry to blanket some unsightly ence or pile of stone.

\section{TALL OR CLIMBING}

Butterfly. Light vellow, with blotch of deep red on lower petal.

chameleon. A mixture of changing and! inconstant shades all richly colored and on the same plant.

King of the Blacks. Dark red flowers and dark foliage.

Lucifer. Blossoms deep crimson, leaves brownish green.

Pearl or White. Light lemon or primrose.

Rose.

Ruby. Very deep rose pink.

Spitfire. Brilliant flame color scarlet.

Yellow.

\section{DWARF}

Aurora. Yellow, veined carmine. Chameleon. A dwarf mixture of blotched and inconstant shades on one plant.

Cloth of Gold. Bright golden yellow leaves and brilliant scarlet flowers.

Dark Crimson. Very dark, rich crimson scarlet.

Empress of India. Intense scarlet, foliage dark browr and green. King Theodore. Very deep crimson and dark foliage, the darkest of all, nearly black.

Rose or Pink.

Ruby King. Bright red, tinted salmon.

White Pearl. Very light lemon or primrose.

\section{MIXED NASTURTIUM}

Tall Mixed Garden. Grown not only for ornament but the beautiful orange colored flowers and foliage are used for garnishing and the young leaves or shoots are excellent for salads. The green seed pods are greatly esteemed by many for use in mixed pickles.

Dwarf Mixed Garden. Same as above except that it grows in dwarf form.

\section{SWEET PEAS}

In few lines of endeavor has the adrancement been so rapid as in the derelopment of sweet peas. This the public seems to appreciate and this flower is today a general favorite.

If possible, for sweet peas spade deeply a well drained soil in the fall and add any good compost, including some wood ashes or lime. As early as the ground can be worked in spring plant the peas in a trench five inches deep and cover with one inch of sand or tine soil. When the peas a re well above the ground fill the trench and thin the peas to stand two to three inches apart in the row. When planted, or very soon afterward, set some four to fire-foot supports. Mulch with lawn trimmings, water thoroughly oncea week, and cut frequently to keep the plańt flowering. ports. Mulch with lawn trimmings, water thoroughly oncea wee

\section{GRANDIFLORA VARIETIES}

America. Crimson scarlet, striped on white.

Aurora. white.

Black Knight. A very deep maroon. Blanche Ferry. Standard bright carmine rose, wings white tinged with pink.

Countess of Radnor. Light mauve standard, lavender wings.

Dorothy Eckford. Pure white.

Duke of Westminster. Standard clear purple, wings purple with tint of violet.

Emily Henderson. Pure white, white seeded.

Katherine Tracy. Standard soft pink, wings a trifle lighter tone.

King Edward VII. Bright red or crimson scarlet.

Lady Grisel Hamilton. Standard light mauve, wings lavender.

Lord Nelson. Rich deep navy blue. Mrs. Collier. Primrose.

Mrs. Geo. Higginson, Jr. Light lavender.

Mrs. Walter Wright. Rose purple.

Prima Donna. Pure pink self.

Shasta. Pure white.

\section{SPENCER VARIETIES}

Asta Ohn. Pinkish lavender.

Clara Curtis. Primrose.

Countess Spencer. Bright, clear pink on white ground.

Elfrida Pearson. Deep blush.

Elsie Herbert. Large white with beautiful picotee edge of rose pink.

Florence Morse Spencer. Light pink.

George Herbert. A bright rosy carmine.

\section{MIXED SWEET PEAS}

Choice Mixed. The best blending of the choicest named varieties. better mixture can be had.

Eckford Mixed. A very choice mixture of the Grandiflora types.

Florists' Mixed. A blend of the sorts best suited for the cut flower trade.

Named Sorts Mixed. Blended from the named sorts of the Unwin and

Spencer Varieties Mixed.

Helen Lewis. Standard orange, wings rosy salmon.

Edward Spencer. Rich crimcream ground.

thello Spencer. Rich deep maroon.

Spe best purple

Emperor. Bright scarlet. .

White Spencer. Pure white.
Iargaret Atlee. Apricot pink on Sweet Pea.

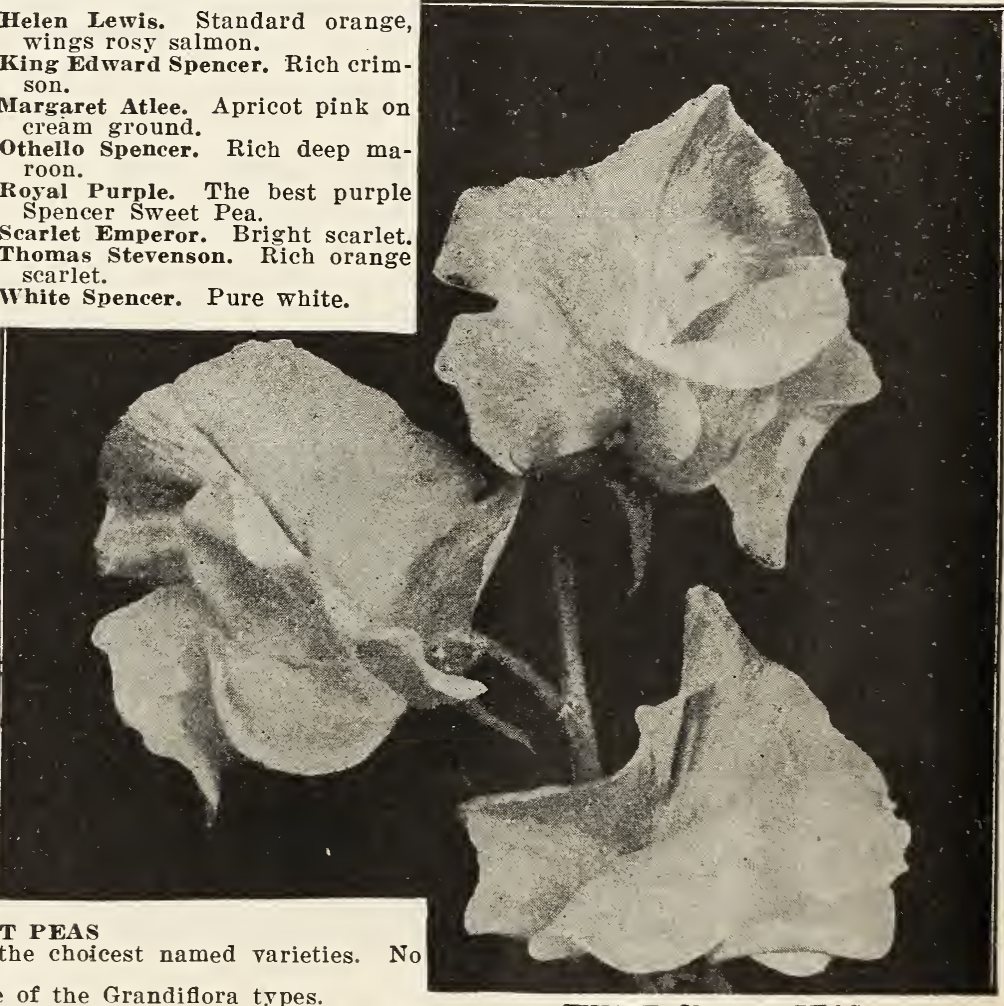

WHITE SWEET PEAS

types. 


\section{CHOICE FLOWER SEEDS}

\section{STANDARD VARIETIES}

Most flowers are as easily grown as vegetables. In the select list that follows will be found flowers and plants for many uses. Some plants used for cuttings bring the sunshine to those that must live indoors, while others are useful for cemetery lots, a tribute to those that precede us. Some plants can be grown in a partial shade, where grass does not grow, and others are serviceable in hanging baskets or veranda boxes. Some vines or tall plants may be grown to hide or make more sightly some fence or pile of stone or stump or building. Flowers are just as necessary as are pictures, and to their beauty is often added such stimulating and pleasing perfumes as cannot be bought in bottles.

Flowers fall readily into three classes: Annuals bloom, seed and die the first year. Biennials bloom and die in their second year, but they may bloom also in their first year. Perennials flower for several years and some of them may bloom in the first year of their existence.

\section{ASTERS}

Of the general beauty of these flowers it is unnecessary to speak; the immense world-wide demand for them shows their adaptability for any climate; and, coming into bloom, as they do, when most other tlowers are fading away, enhances their value. For the best results the ground for the cultivation of asters cannot be too richly prepared, although they will give satisfactory returns on any ordinary garden soil.

New Giant Comet Asters, Mixed. With good cultivation, flowers of this type frequently measure four inches across, and in their fine form, large size, and long stem approach in beauty the fine Chrysanthemuins grown in the greenhouse during the late fall months. White, lavender, crimson, mixed.

Queen of the Market. Of graceful spreading habit, it is in full flower two weeks before most other asters. Deep blue, white, pink, and rose in mixture. White, lavender, crimson, pink, mixed.

Semple's Branching Mixed. All colors mixed of this favorite long-stemmed strain.

Mixed Asters. Many varieties of different types.

Acroclinium. Summer flowering and an "everlasting."

Ageratum (Floss Flower). For edging or pots.

Alyssum, Sweet. Trailing and fragrant.

Alyssum, Little Gem (Carpet of Snow).

Amaranthus. Tricolor (Joseph's Coat).

Antirrhinum. (Snapdragons). Tall mixed.

Antirrhinum, Tom Thumb. Mixed, fine strain.

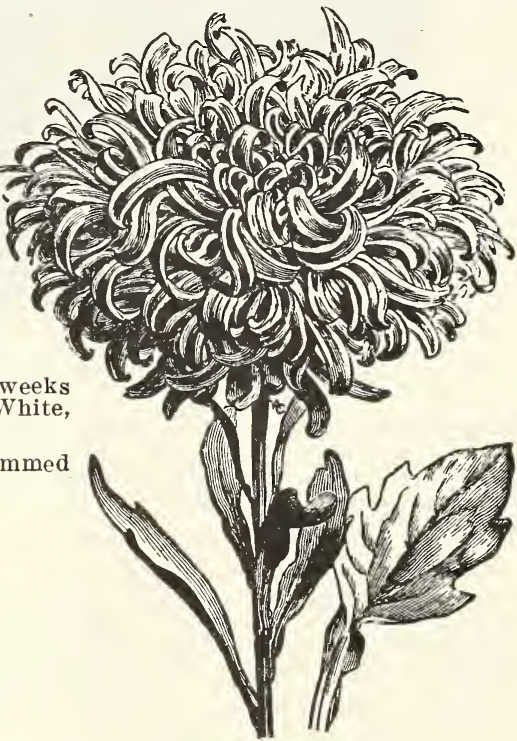

COMET ASTER

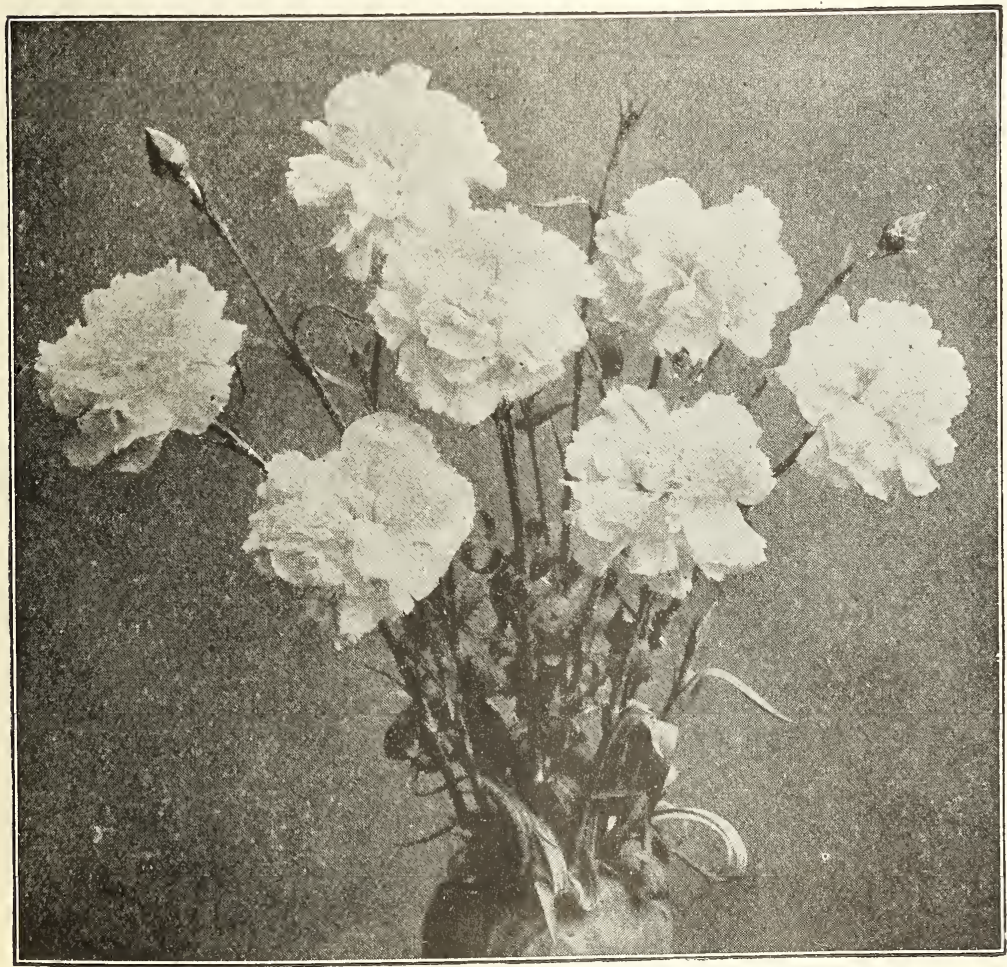

Bachelor's Button (Ragged Sailor or Corn Flower).

Balloon Vine. A white flowered climber.

Balsam (Lady Slipper). A garden Hower.

Calliopsis or Coreopsis. For bedding. Candytuft. For cutting or beds.

Canterbury Bell. A hardy biennial.

Carnation. For pot and outdoor culture.

Castor Beans. See Ricinus.

Celosia or Cockscomb. For the garden or in pots.

Chrysanthemum. Summer flowering and for cutting.

Cobea Scandens. Bell-flowered, rapid climber.

Cosmos. For autumn flewering background.

Cypress Vine. F low e r e d rapid climber.

Dahlia. A late summer and autumn flower.

Daisy. Fine quality double mixed.

Delphinium Mixed.

Dianthus. P in ks. Old-fashioned favorite.

Double Chinese Mixed.

Double Diadem.

Single Mixed.

Eschscholtzia or California Poppy. Fine Mixed.

Forget-Me-Not. For the shaded spot. Four o'Clock (Marvel of Peru).

Fox Glove or Digitalis. For the half shade.

Godetia. For borders and pot culture.

Gourd. Apple Shaped, Bottle, Dipper, Dish Cloth, Hercules Club, Japanese Nest Egg, Mock Orange, Pear Shaped, Sugar Trough.

Gypsophila (Baby Breath). For edg. ing. 


\section{CHOICE FLOWER SEEDS-Continued}

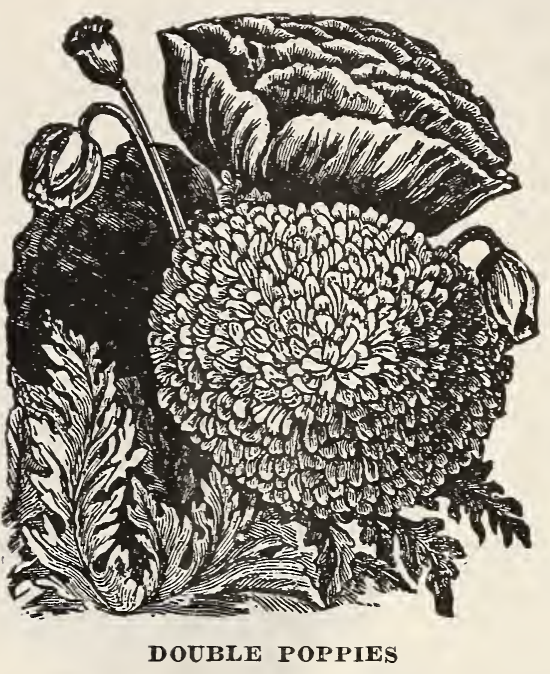

Heliotrope. For bedding, bouquet and its perfume.

Hollyhocks. For a tall background.

Hyacinth Bean. A flowered climber.

Ipomoea. A flowered rapid climber.

Setosa (Brazilian Morning Glory).

Grandiflora (Moon Flower).

Job's Tears. Grass with slate colored seeds.

Kochia (Summer Cypress or Burning Bush).

Larkspur. For bedding or cutting.

Lobelia. For pot culture or bedding.

Marigold. Bedding or borders.

African Double. Orange color.

Eldorado. Several shades of yellow.

French Dwarf. Brown-red.

Mignonette. For cutting and its perfume.

Sweet. The old variety.

Golden Queen. Fragrant and yellow.

Machet. Red flowered.

Morning Glory. The well known climber.

Japanese mixed.

Fine mixed.

Portulaca. The Moss Rose.

Single mixed.

Ricinus. Flowering castor bean.

Zanzibariensis.

Sanguineus.

Salpiglossis. For border or bedding.

Salvia Splendens. Scarlet Sage.

Bonfire.

Mixed.

Stocks. Ten Weeks.

Choice mixed.

Yellow.

Blue.

White.

Sun Flower. For screen or background.

Sweet William. For beddins and borders. Single mixed.

Double mixed.

Verbena. For window boxes or bedding.

Wild Flower. Garden mixture.

Zinnia. For bedding and bouquets.
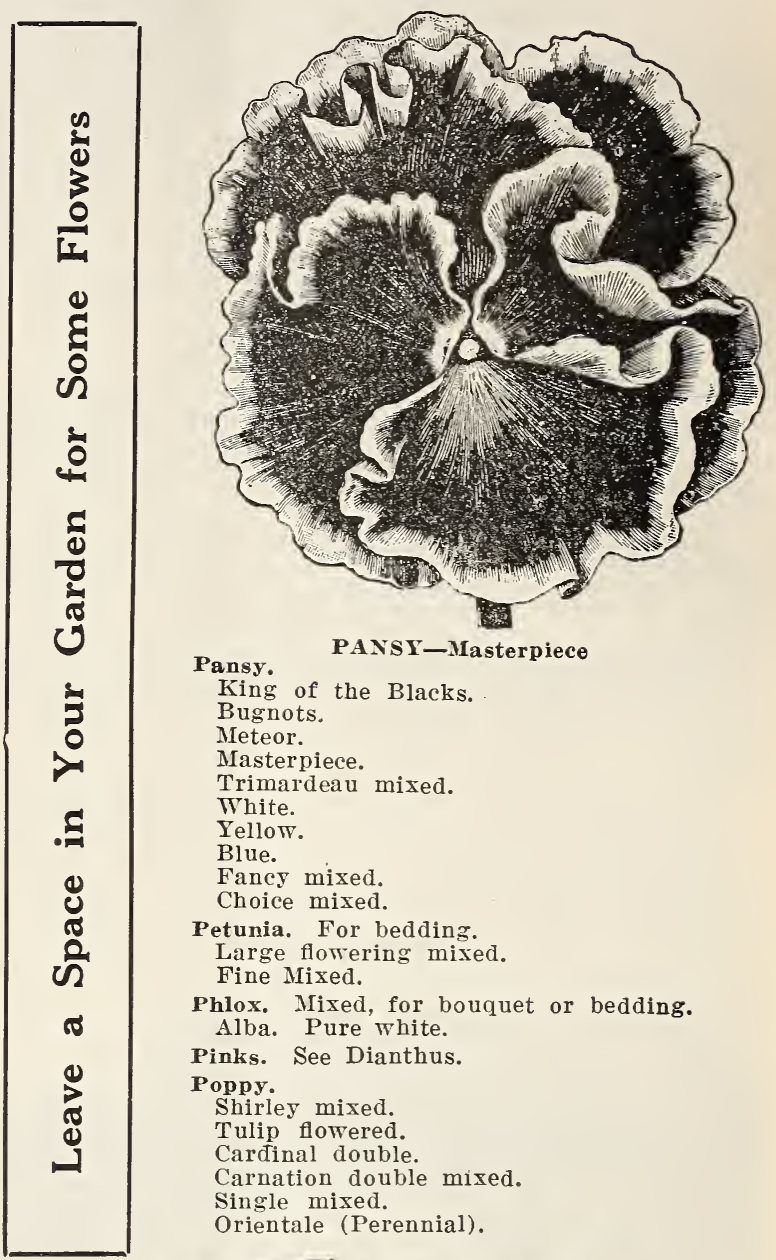

Pansy.

King of the Blacks.

Bugnots.

Meteor.

Masterpiece.

Trimardeau mixed.

White.

Blue.

Fancy mixed

Choice mixed.

Petunia. For bedding.

Large flowering mixed.

Fine Mixed.

Phlox, Mixed, for bouquet or bedding.

Alba. Pure white.

Pinks. See Dianthus.

Poppy.

Shirley mixed.

Tulip flowered.

Cardinal double.

Carnation double mixed.

Single mixed.

Orientale (Perennial).

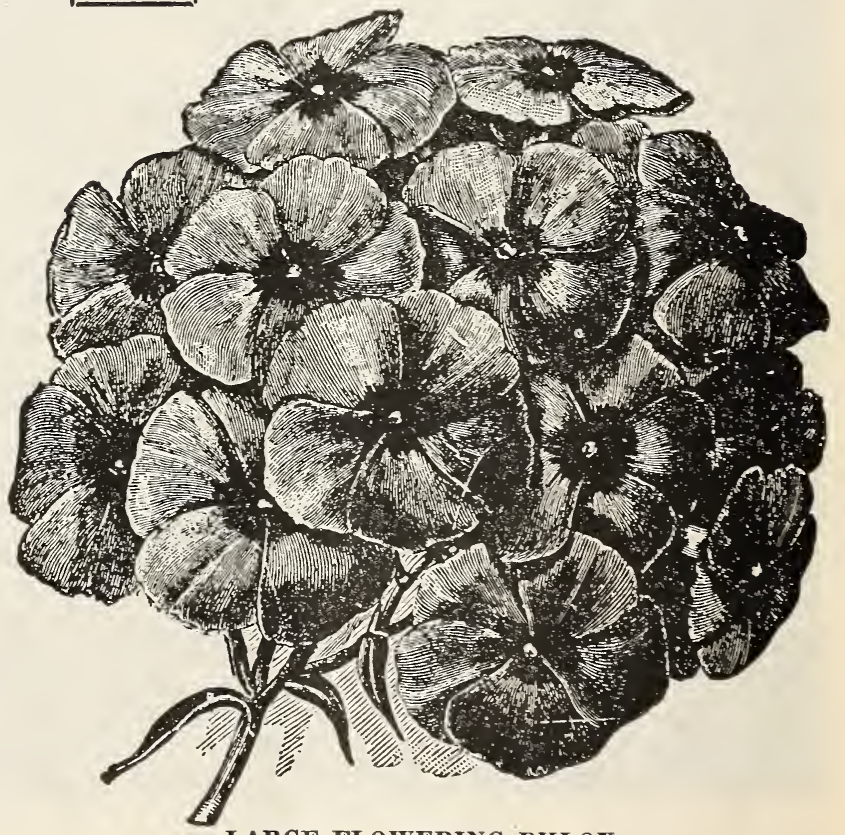




\section{LAWN GRASS}

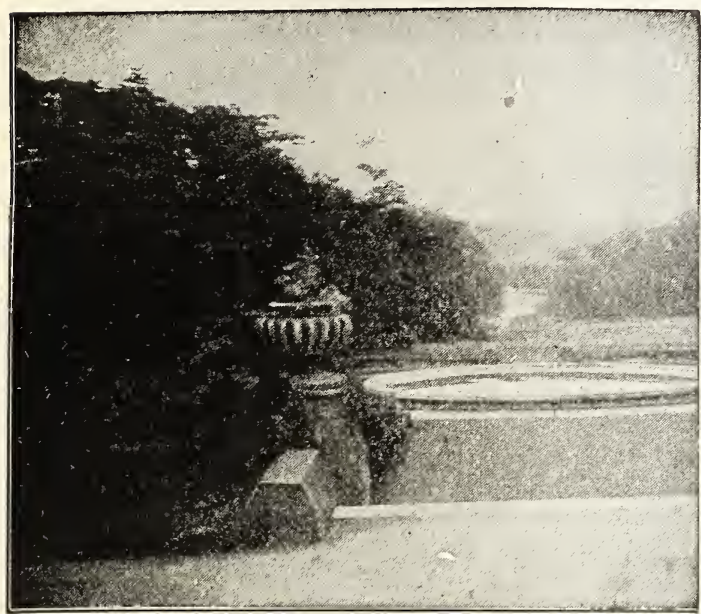

Your outdoor carpet should be of an even colored grass that grows so close that weeds cannot get through. Think of your lawn as a number of plants, not "just grass." These lawn plants ask what other plants require: good drainage, a soil of a fit quality, the addition of lime where soil is sour, deep preparation by spading or plowing, the addition of fertilizers before planting and from time to time afterwards as the plants continue to feed, and good seed. Where manure is used at any time it should be thoroughly decomposed and free from weed seed and a complete fertilizer at the rate of five hundred pounds to the acre is advantageous.

Seeding had best be done in the spring or fall. Be careful to have the entire surface as near alike as possible that the grass may be even in its growth and finish by using a fine rake and a heavy roller. Seed heavily. Use seventy-five pounds of the best lawn mixture to the acre, or one pound to three hundred square feet. Sow the seed carefully on a calm, drs day and rake lightly.

Cut the lawn frequently, setting the machine to cut as high as possible, and as weeds grow where grass seed is now sown, weeds will grow in your lawn and some of them it may be necessary to dig out with a knife.

In very dry weather a thorough wetting should be given about once a week, a little water on a dry surface doing more harm than good.

Each spring after the winter heaving of the lawn by frost is over, the lawn should be re-rolled while the soil

Park Lawn Grass Mixture. For quickly producing a permanent, thick and velvety sward of grass, this brand of lawn grass cannot be excelled. It is the best mixture of grasses we sell for lawn making, and will give satisfaction wherever sown.

Mixture for Shaded Spots. Usually it is quite difficult to obtain a satisfactory growth of grass under trees and in shady places; for sowing in such places we recommend the use of this special mixture. It will quickly produce an abundant and even growth of keautiful green grass.

\section{GRASS SEED}

Blue Grass. (Poa Compressa.) Commonly called Canada Blue Grass. A very valuable grass for pasture and lawns.

Blue Grass. (Poa Pratensis.) Commonly called Kentucky Blue Grass and known in some sections as "Green Meadow Grass" and "June Grass." It is the best pasture for our climate and soil, succeeding finely on hill lands and producing the most nourishing food. Sow early in the spring or during the months of October and November. Faricy clean seed.

Red Top. (Agrostis Vulgaris.) A valuable grass for moist soils and low lands. It is a good, permanent grass, standing our climate well.

English Rye Grass. (Lolium Perenne.) A very nutritious rapid growing variety, valuable for meadows and pastures. Twenty-four pound bushel.

Italian Rye Grass. (Lolium Italicum.) A valuable European variety, adapted to any climate, and produces large and nutritive crops. Eignteen-pound bushel.

Meadow Fescue or English Blue Grass. (Festuca Pratensis.) Needs rich ground, and succeeds well on prairie soil. Sow about twenty-five pounds per acre.

Tall Fescue. (Festuca Elatior.) A valuable perennial grass, very productive and nutritious. If used alone, sow forty pounds per acre.

Creeping Bent Grass. (Agrostis Stolonifera.) Particularly valuable for lawns that are to be used as croquet and tennis grounds.

Orchard Grass or Rough Cocksfoot. (Dactylis Glomorata.) This is one of the most valuable and widely known of all pasture grasses. It is well adapted for sowing under trees or orchards.

Timothy. (Phleum Pratense.) This is decidedly the best grass for hay.

\section{CLOVER SEED}

Medium Red or June. (Trifolium Pratense.) Sow in spring or fall, at the rate of eight or ten pounds per acre Mammoth or Large Red. (Trifolium Pratense.) Sow at the rate of about eight pounds per acre. Sixty pounds per bushel.

White Dutch. (Trifolium Ripens.) A small. creeping, spreading, perennial variety, valuable for pasture and lawns,

Alfalfa or Lucerne. (Medicago Sativa.) Will bear cutting three or four times during the season. For bringing up poor land it is the best of the clovers.

Alsike or Swedish. (Trifolium Hybridum.) This valuable variety is fast gaining great popularity.

Crimson or Scarlet clover. Can be seeded at any time from June to October, at the rate of fifteen to twenty pounds per acre.

\section{MISCELLANEOUS GRAINS FIELD PEAS \\ BROOM CORN}

White Canada.

Blue or Green.

Black Eye.

COW PEAS

Whip-Poor-Will.

\section{MILLET SEED}

Japanese Barnyard.

Siberian.

Hog.

Common.

German or Golden.

Hungarian.

Early Ambe:

SUGAR CANE

Early Orange.
Improved Evergreen.

Early Japanese.

MISCELLANEOUS

Barley, Comimon.

Rye, Spring.

Rye, Winter.

Buckwheat, Silver Hull.

Buckwheat, Common.

Buckwheat, Japanese.

Spurry.

Vetch, Sand or Winter.

Vetch, Spring.

\section{BIRD SEEDS}

Canary.

Hemp.

Lettuce.

Millet.

Bird Rape.

Sunflower.

Mixed Bird Seed.

PRICES VARY ON ALL FARM SEEDS.

Write for Market Price. 


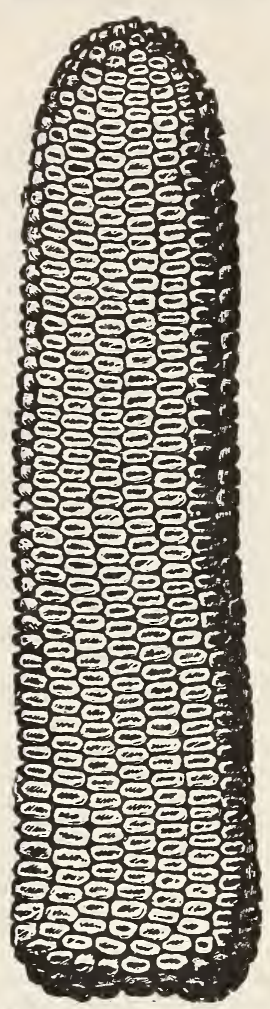

\section{FIELD CORN \\ Prices Change. Ask for Market Price}

Pride of the North. This famous corn still retains its popularity; an exceedingly early and prolific variety, always maturing in ninety days; often shelling sixty-two pounds of grain from seventy pounds of ears. Kernels closely set, large, of deep orange color; cob very small and red; stalks about seven feet in height. This is, probably, the best Dent corn for general cultivation in the North.

Reid's Yellow Dent. This variety has won more prizes at corn shows than any other corn. It matures a ten-inch of eighteen to twenty-four rows in one hundred fifteen days.

Improved Leaming. The Improved Leaming Corn is a medium early yellow variety; large, slightly tapering ears, deep grain, and medium sized red cob. In favorable years there is much uniformity of both kernels and ears. Its numerous broad leaves not only encourage a healthy development but make it a valuable variety for feeding.

Minnesota No. 13 or Wisconsin No. 8. A ninety-day variety producing ears averaging eight inches in length with sixteen to twenty rows of bright, rich yellow, smooth, wedge shaped kernels, packed closely on the cob from tip to butt. The best yellow Dent for northern planting.

Champion White Pearl. Originated in Illinois, and is enormously productive; a strong grower; matures in about one hundred days. The stalk is stout and thick, with large ears set low.

Iowa Gold Mine. A splendid yellow corn. Everyone who has tried it is enthusiastic in the praise of this splendid variety which was introduced in 1892. It has everywhere received the most cordial endorsement as one of the best and most profitable varieties ever grown.

Iowa Silver Mine. The Iowa Silver Mine is a splendid white corn. In 1894, the poor corn year, it yielded at the rate of ninety-seven and one-third bushels to the acre. It has no barren stalks. The ears are very even in size, being but little smaller at the tip than at the butt, and corn is well filled out over the tip.

Longfellow Flint. This is an eight-rowed Yellow Flint Variety, the result of careful selection. The ears are from ten to fifteen inches long, one and one-half to one and three-fourths inches in diameter, are well filled out to the extreme end of cob.

KAFFIR CORN. One of the best forage plants. If the crop is wanted mainly for fodder, it is recommended to cut down the whole stalk when the first seed heads come into bloom.

DWARF ESSEX RAPE. A forage plant of great merit, easily grown in any part of the United States, on any land that will raise turnips or corn, and will furnish abundant supplies of succulent, rich, nutritious pasture, at a season when it is most needed.

RUSSIAN SUNFLOWER. This is highly prized by poultry raisers and farmers as a cheap food for fowls. It is immensely productive and can be raised cheaper than corn, as any waste MPROVED LEAMING piece of ground will suffice. It is the best egg-producing food known.

\section{PERFECTION GARDEN CULTIVATOR}

Different from Others-Superior to All.

The lightest garden tool on the market.

Easiest to adjust.

Strongest in workmanship.

Easiest to operate.

Is a complete machine within itself.

Needs no extra parts.

The only garden tool made that throws the soil to or from the plants without extra attachments.

Is made in three sizes, viz:

No. 1. With two dises, on which 6-inch or 7 -inch knives may be used.

No. 2. With four dises, on which $7 \frac{1}{2}$-inch, $81 / 4$ inch or $83 / 4$-inch knives may be used.

No. 3. With four dises, on which 10-inch or 11-inch knives may be used.

\section{BULBS, PLANTS, ETC.}

Bulbs, Plants and Shrubs are in a class by themselves. There are bulbs for spring planting and bulbs for fall planting. Some shrubs do best when planted in the spring, others when planted in the fall. Roots of the perennial plants may be planted in fall or spring. Plants of the small fruits usually do best when planted in the spring. When ready to order your supplies in this department let us figure on your needs.

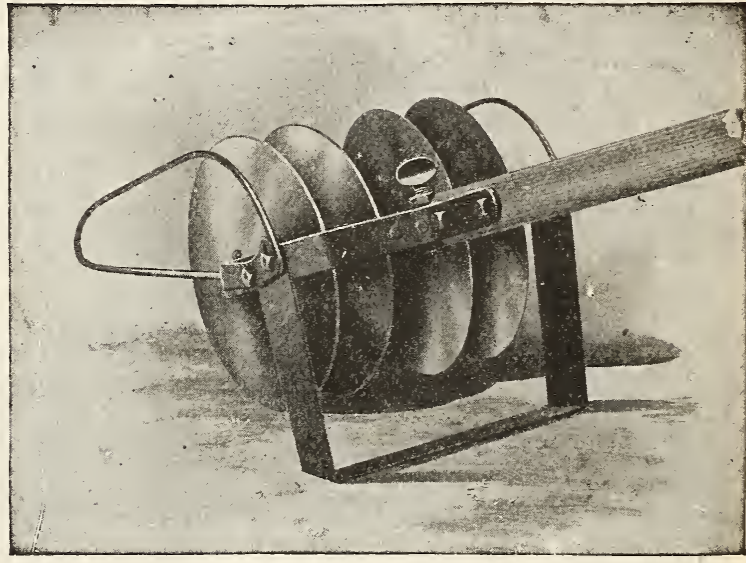

\section{FERTIIIZERS}

Fertilizer Values Vary. Write for Prices.

The value of Commercial Fertilizer is well known. There are many different brands and combinations-each of which has its value for certain crops and conditions of soil. The element that is lacking in the soil is what the special fertilizer supplies. Write for our prices and for information as to kinds. 


\section{NOTES ON GARDENING}

While it is in a way true that anyone can garden, intelligence tells more quickly in agriculture, possibly, than in any other line of endeavor. Yet so many and varied are the ways of reaching a result in agriculture that no two experienced and successful growers would agree entirely upon the treatment of a crop or a piece of land. It does not follow that either grower is right or wrong, we would rather say that in the agricultural seas there are many good pilots with well charted courses and bid them "bon voyage."

In the work of gardening a sharpened stick or at most a hoe and spade is all that is absolutely necessary, but the result will be vastly improved by the use of modern tools, hotbed frames and sash, some insecti. cides and a fungicide, drain tile, a compost heap and fertilizer.

Hotbeds. While early in the year plants may be started in a sunny window, it is of profit and advisable to use hotbeds and cold frames for even a small garden. From the first to the latter part of March is quite early enough to make a hotbed. The time must vary according to the latitude. Provide a quantity of fresh horse manure from the stables, and add to this, if they can be had, one-third to one-half its bulk of leaves. Mix them thoroughly, tramping down the mass in successive layers, and form into a large pile, so that fermentation will proceed, even in severely cold weather. In two or three days fermentation will be apparent by the escape of steam from the heap. Now turn again, all allow the heap to remain two or three days longer, or until the second fermentation commences. Make an excaration or pit $2 \frac{1}{2}$ feet deep, and of a size suited to the number of plants required. The pit will be better if built up of brick. It should be made in some dry, sheltered spot, facing the south or east, if possible. Hotbed sashes are usually $3 \times 6$ feet, and one or two sashes will give early plants enough for a small family. The frame for sashes should be 18 inches high at the back and 12 inches in front, which will give the proper slope to catch the sunlight. Cross-pieces should be placed for the sashes to slide on, to facilitate opening and shutting the frames. When everything is ready, the manure is placed in the pit and trodden down firmly in layers to the required depth, 2 to $2 \frac{1}{2}$ feet. Then put on the sashes, and keep the pit closed until the heat rises. At first it will probably be 100 degrees or more, which is to hot to sow the seed in; but in two or three days it will subside to 90 degrees or a little less, when the soil may be put on to the depth of 6 to 8 inches. The heat may be readily ascertained by plunging a thermometer into the manure. The soil should be of well-rotted sod (or common garden soil will do), mixed with about a third of fine old manure; and in this the seeds may be sown thinly in drills 2 to 3 inches apart, and afterward (as soon as ont of the seed-leaf), either thinned out or else transplanted to another frame. Air must be given every mild day by raising the sashes at the back. Water with tepid water whenever necessary, and during cold nights and snowstorms keep covered with mats or board shutters. Tomatoes, Peppers and Egg Plants should be sown in a separate frame from Cabbage, Cauliflower and Lettuce, as they require more heat. The same directions may apply to hotbeds made or the surface of the ground, except that the manure should be at least a foot wider on all sides than the frame.

Cold Frames are simply frames with tops of glass or cloth set on the ground, no bottom heat being applied. It is banked up on the outside during the winter with marsh hay, straw or coarse litter. The soil is prepared by forking in and thoroughly mixing to the depth of 10 or 12 inches a liberal quantity of old, well-rotted manure. The manure of an old hotbed is good for the purpose. The frame is prepared in the fall, and young Cabbage, Cauliflower and Lettuce plants are set out in it in time to get well established before very cold weather. Cauliflower and Cabbage should be set down to the first leaf, and the soil made firm around the plants. The seed is usually sown, in this vicinity, from the 15 th to the 20 th of September. The young plants will be ready to transplant in about 25 to 30 days. vicinity, from the 15th to the $20 \mathrm{th}$ of September. The young plants will be ready to transplant in about 25 to 30 days. by straw mats or slutters. Cauliflower needs more and closer protection than Cabbage, and it is rather more tender. During mild days admit air freely, the object being to keep the plants in a dormant state, without actual freezing, so that when spring comes, they are in a forward state for setting out. Seeds of Cabbage, Cauliflower, Lettıce and Radish may be sown in a cold frame in the spring from the last week in February to the first week in March. The frame should stand in a warm and sheltered spot, and be kept from freezing by mats or a thick covering of straw during cold nights.

Even before the hotbeds are made or the first seed purchased the garden should be planned on paper.

If the garden has not been drained, preferably by tile, and there are very few pieces of ground that do not need drainage, an effort should be made to get rid of the surplus water so that the soil may warm up rapidly and bacterial life so necessary to plant life begin.

Frequently the application of lime or limestone is more necessary than the application of commercial fertilizer and this question, too, must be answered early.

Stones and stumps, along with trees of no ralue, should be remored from the garden, and every effort possible made to get ready for the rush that comes with spring planting. There are easy ways as against the difficult wars of gardening, and from time to time the work should be carefully thought over with the idea of saving every effort possible. First of all, the vegetables should be planted in long rows, so with a wlyeeled tool like the Perfection Garden Cultivator in an upright position and avoid the backaches and suffering of other years by using a Masters' Rapid Plant Setter. Tools like these should be secured before the day they are needed.

\section{LOCAL NAMES OF SEEDS}

We frequently have calls for seeds under names that are not generally found in the catalogue. In most cases of this kind there is a standard catalogue name for the article and we usually locate it easily from the description the customer gives of it. If you do not recognize the desired article from the catalogue names let us know and we shall endeavor to locate it and get it for you if we do not have it in stock.

\section{SUNDRY REQUISITES AND SUPPIIES}

There are many requisites and supplies that we do not have room to list in our catalogue. We aim to have all seasonable articles on hand and can supply all of these at the time they are required. There are different makes of tools, different brands of requisites and different kinds of supplies all having merit. When we know what you prefer in any of these lines we can meet your requirements. 


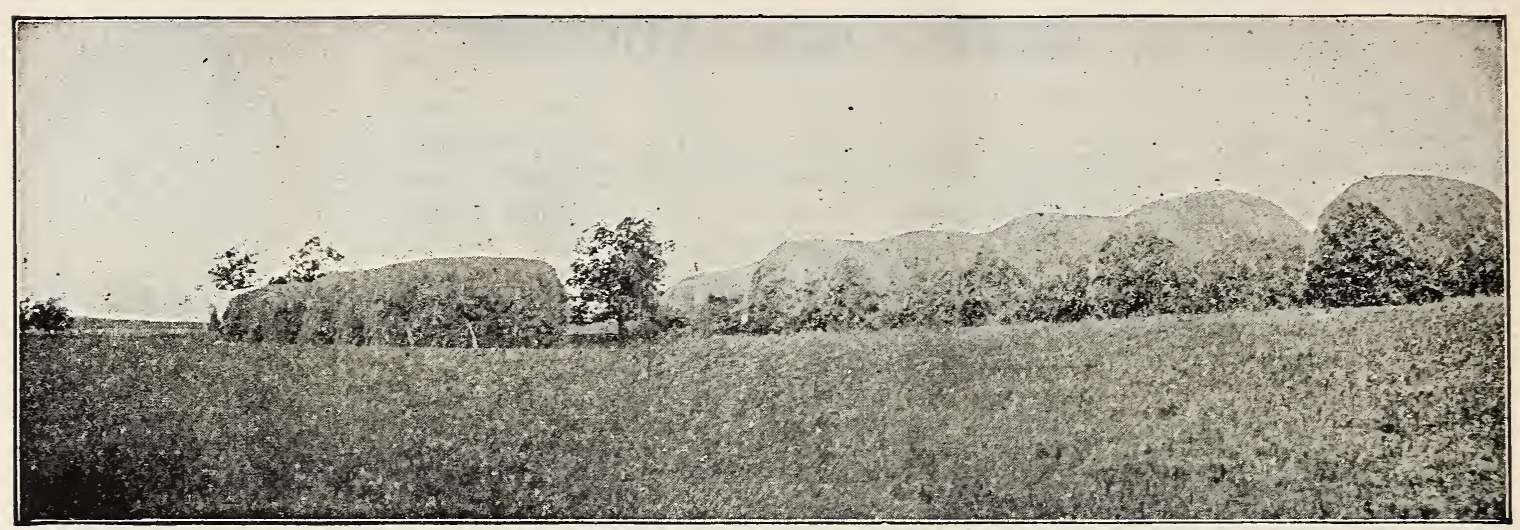

\section{FERTILIZERS}

Fertilizer. Any material used as a manure for the soil. Fertilize, to enrich, to impregnate. The foregoing definition tells us that any material used as a manure is a fertilizer, but as different soils require different elements to enrich it and make it more fertile, thus some soils may be rich in Nitrogen and have no Phosphoric Acid (animal) or Potash in it, it is best then to use a Fertilizer that has both those elements in it (See list) and any soil with the three elements mentioned above, is especially good for the raising of all field crops and for the Market Gardener. Also some soils are lacking in Phosphates and have all the others so the addition of Phosphates to soils only lacking in that one element is necessary. In these days of advanced knowledge in the cure of soils it is almost criminal in a Market Gardener or farmer to be ignorant, for our Agricultural Colleges have departments for the careful analysis of soils, so it would be to your advantage to send a fair sized sample of soil from different portions of your land to the nearest College and they will analyze it and report the exact elements needed for you to grow better crops on your land. On our page devoted to various brands of Fertilizers, you will find the analysis of each brand and after getting your report from the College you can then safely select the brand best suited to your land needs.

Fertilizer is a big word. Shade from trees or buildings is another lack of fertility. The poisonous fumes from factories kill plants, so plants do breathe. After all, much or most of our fertilizer is just sunlight or air. While most of the world's fertility does not reach us as freight, some very good fertilizers that it is wise to use does come done up in bags.

Think of the organisms or bacteria that live in the soil as laborers living and working in their home and that they need material with which to work. These tiny workmen, we say, make the plant food available. So not only are workmen necessary, but we must supply them with the raw material with which to work. Some of the things we may add to the garden may contain with new workmen, call them microorganisms if you wish, one or several raw materials as well. Other materials we supply to our gardens may contain only these elements or materials which we class as phosphates, potash and nitrogen. We say a fertilizer is complete when it contains these last three elements put up in bags and known as commercial fertilizer. If the manufacturers of commercial fertilizer have had a weakness it has been in.their lack of effort to teach that their product is not an able and necessary use. Such a use must go hand in hand with other good practices, like soil draining, subsoiling, liming, deep plowing, stable and green manuring, the rotation of crops, possibly the rotation of fertilizers, thorough cultivation and the use of good seed.

The Compost Heap. The gardener or farmer had best select a spot removed from the residence and there save continually all grasses, leaves, poultry and stable manure, soot, hoof and horn parings, bones, unused vegetables and fruit and refuse from the table. Earth and phosphate can be added to this compost heap, and while the heap should be kept moist enough to decay, it should be protected by a roof from rain. Later this compost should be spread upon the soil and plowed or spaded in. This is not only a great economy, but is also very beneficial.

Pulverized Sheep Manure. Humanity builds the results of its learning into little sayings; of them one is, "The sheep's foot is gold." Generations of farmers learned that where the sheep were kept or pastured later grew rich crops. So we are offering, sheep manure that has been pulverized, screened and dried till it contains no weed seed and is in the most perfect condition for handling. Where the ant was found to follow the application of bone meal to lawns, the application of this Pulverized Sheep Manure was followed only by good results. Its effect is not only immediate but lasting. For a potting soil one part of this manure to six parts of the soil was found to be preferred. For the making of a liquid manure one pound to six gallons of water was superior. It has no objectionable odor, nor does it offend by its appearance. When heavily and freshly applied to lawns it is barely discernible. A heavy application is not to be feared but to be advised for house plants, lawns, flower gardens, fruit or vegetables. Prices upon request. 


\section{A PAGE ON FUNGICIDES AND INSECTIDES}

The attempt to summarize the militant ways of man in his battle with disease, fungi, and insects that attack our plant world, would be, because of its brevity, somewhat imperfect. This quickly developed science that is rapidly progressing fills volumes of space. In the effort to be brief, which means we cannot be concise, we might say of the plants' enemies that they are: first, fungous diseases; second, insects that eat or chew the plant; third, insects that suck the plants' juices; fourth, insects that bore into the plant.

FIRST. The Fungous Diseases of plants may be thought of as blight, mildew, spot, speck, dry rot, black rot, rust, scab or mold, etc.

The remedies applied are called Fungicides. They may be preventative or cures, or both. Some of them are as follows:

Bordeaux Mixture.

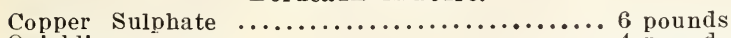

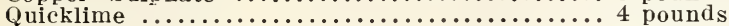

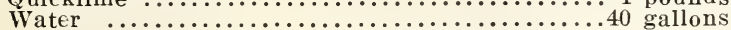

Dissolve the copper sulphate by putting it in a bag of coarse cloth and hanging this in a vessel holding at least 4 gallons, so that it is just covered by the water. Use an earthen or wooden vessel. Slake the lime in an equal amount of water. Then mix the two and add enough water to make 40 gallons. It is then ready for immediate use.

Ammoniaca Copper Carbonate.

Copper Carbonate ...........................1 ounce

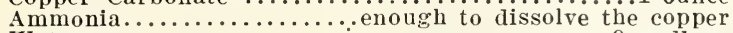

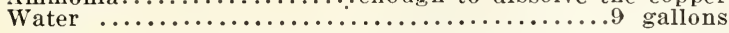

SECOND. Insects that chew or eat the plant may be bugs, caterpillars, worms or slugs. The poisons we feed to this class of our enemies we call Stomach Poisons, and some of them are:

\section{Paris Green.}

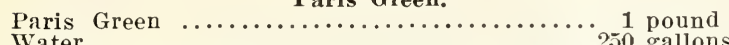

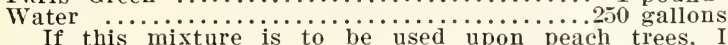
pound quicklime should be added. Repeated applications will injure most foliage unless lime is added. Paris Green and Bordeaux can be applied together with perfect safety. The action of neither is weakened, and the Paris Green loses all caustic preperties. If applied as a powder it should be mixed with flour or plaster, 100 parts to 1 part Paris Green.

\section{London Purple.}

This is used in the same proportion as Paris Green,
The copper carbonate is best dissolved in large bottles, where it will keep indefinitely, and it should be diluted with water as required.

Copper Sulphate Solution.

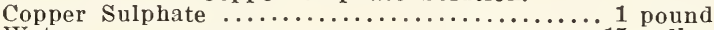

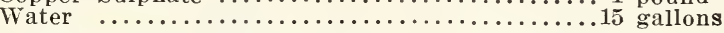

Dissolve the copper sulphate in the water, when it is ready for use. This should never be applied to foliage, but must be used before the buds break. For peaches and nectarines use 25 gallons of water.

Practically all insecticides and fungicides are now put up in concentrated form, saving the gardener the tronble of mixing the ingredients. Frequently this prepared article is superior to that which could be mixed at home,
and often cheaper. In this buying one has a choice as between the fluid, paste or dry forms at times.

but as it is more caustic, it should be applied with lime or with the Bordeaux Míxture.

Fresh White Hellebore........................ ounce

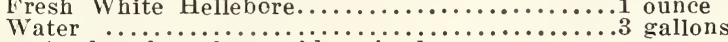
Apply when thoroughly mixed.

\section{Arsenate of Lead.}

Among the insecticides none stands higher than this. It adheres and does not injure the most tender foliage. does not readily wash off, and as it is white it shows where it has been applied. It remains so well suspended in solution as to give an even distribution.

THIRD. Insects that suck the juices of plants may be plant lice mealy bug green and black fly, red spider, scale, etc. The poisons we apply to this class of our enemies kill by striking through the insect's skin, and are referred to as Contact Poisons. Some of them are:

Kerosene Emulsion.

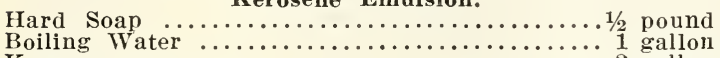

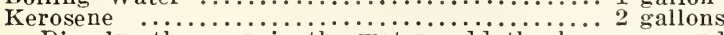
Dissolve the soap in the water, add the kerosene, and churn well with soap for 5 to 10 minutes. Dilute 10 to 15 times before applying.

\section{Tobacco Dust or Tea.}

The aphis or plant louse is not apt to go where there is tobacco dust, and a tea made from tobacco-just tobacco boiled in water till the water is dark-is an excellent remedy for this class of pest.

FOURTH. Insects that bore into the tree or plant are retarded or injured by having Tanglefoot put in their way or 'ish-Oil Soap or Whale-Oil Soap smeared or washed upon the plant's trunk.

Freq antly some combinations of the above Fungicides and Insecticides may be made with advantage, as Bordeaux with Arsenate of Lead, or Kerosene Emulsion with Paris Green. Again, in advertised articles upon the market are found some very superior combinations, one of which we list below.

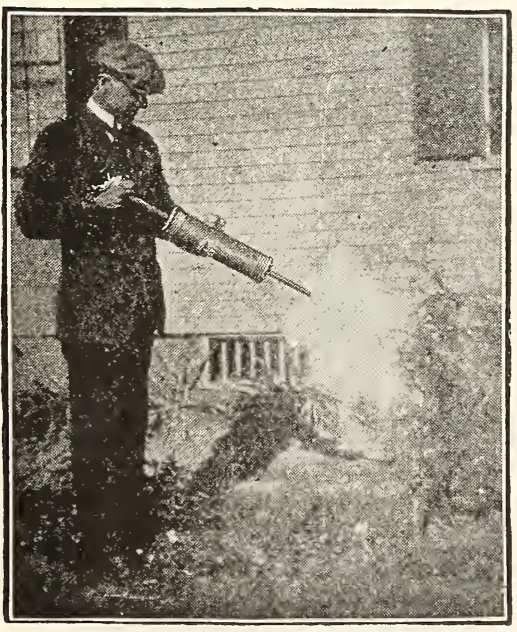

Applying Corona Mixture

\section{GARDEN PESTS AND THEIR CONTROI}

The suburban dweller, the diversified farmer, and the owner of the small country place have always been seriously handicapped in their efforts to combat insect pests, which so often injure or destroy the foliage and fruit of the various plants they attempt to grow.

Experts have realized for a long time that the only method for the protection of the small fruit raiser and home gardener, was a universal insect destroyer-some preparation which would be exceedingly simple to handle, and which would control as many as possible of the insects which infest all manner of growing plants.

\section{"CORONA DRY', SOLVES YOUR PROBLEM}

This product is the result of many years experiment and trial in all parts of the country. It solves the problem of controlling almost all leaf-eating insects, in a particularly efficient manner. 


\section{USEFUL INFORMATION}

LEGAL WEIGHTS \& MEASURES-Pounds per Bushel

\section{ARTICLES}

Apples, Dried

Apples, Green

Barley.

Beans, White

Beans, Castor

Buckwheat.

Broom Corn Seed...

Beets.

Carrots.

Coal, Stone.

Coke.

Corn, shelled

Corn, Ear.

Corn Meal

Cranberries .

Dried Peaches.

Flax Seed

Grass Seed, Blue

Grass Seed, Clover

Grass Seed, Hungarian.

Grass Seed, Millet.

Grass Seed, Orchard

Grass Seed, Red Top

Grass Seed, Timothy.

German Lupine.

Hemp Seed...

Hickory Nuts.

Malt, Barley .

Mineral Coal

Middlings, Fine.

Middlings, Coarse .

Oats.

Onions.

Onions, Tops.

Onions, Sets

Osage Orange

Parsnips.

Potatoes

Potatoes, Sweet

Peas, Dried ...

Peas, in Pods

Quicklime.

Rye.

Salt, Coarse

Salt, Fine.

Turnips, Rutabaga

Turnips, White

Wheat

1 bushel; 36 bushels, 1 chaldron.

Liquid Measure. 4 gills, 1 pint; 2 pints, 1 quart; 4 quarts, 1 gallon; $31 \frac{1}{2}$ gallons, 1 barrel; 2 barrels, 1 hogshead

Measurements of an Acre. The following will be found useful in arriving at accuracy in estimating the amount of land in different pieces of ground under cultivation: 5 yards wide by 968 yards long, contains one acre, as do also the following measurements: 10 yards wide by 484 yards long; 20 yards wide by 242 yards long; 40 yards wide by 121 yards long; 70 yards wide by $691 / 2$ yards long; 60 feet wide by 726 feet long. yards wide by $691 / 2$ yards long; 60 feet wide by 726 feet long; 220 feet wide by 198 feet long; 240 feet wide by $1811 / 2$ feet long; 220 feet wide by 198 feet long; 240
and 440 feet wide by 99 feet long.

\section{Number of Plants or Trees to the Acre at Given}

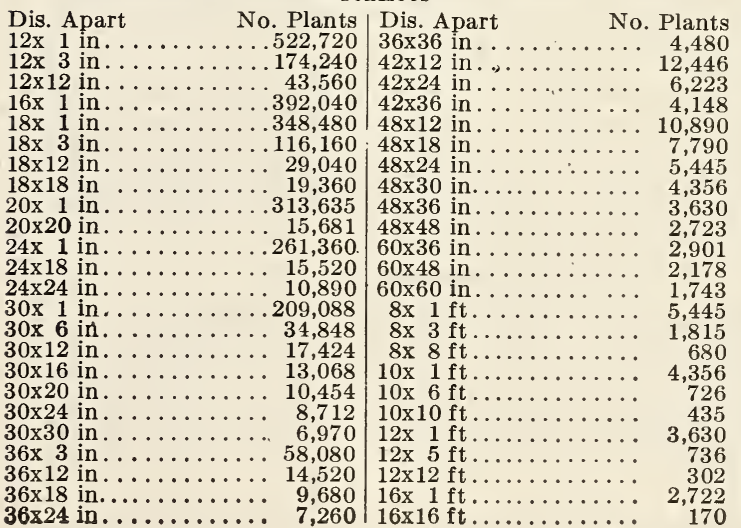

Quantity of Seeds Requisite to Produce a Given Number of Plants and Sow an Acre

Quantity per Acre

Artichoke, $1 \mathrm{oz}$. to 500 plants.

Asparagus, $1 \mathrm{oz}$. to 800 plants

Asparagus Roots.

... 1 lb.

1000 to 72.50

Beans, Dwarf, 1 pint to $100 \mathrm{ft}$ of dril

$21 / 2$ bu.

Beans, pole, 1 pint to 100 hills

Beet, Garden, $1 \mathrm{oz}$. to $100 \mathrm{ft}$. of dirill .

Beet, Mangel, $1 \mathrm{oz}$. to $100 \mathrm{ft}$. of drill .

Broccoli, 1 oz. to 5,000 plants

Brussels Sprouts, $1 \mathrm{oz}$. to 5,000 plants

Buckwheat

Cabbage, 1 oz. to 3,000 plants

Carrot, $1 / 4 \mathrm{oz}$. to $100 \mathrm{ft}$. of drill

Cauliflower, 1 oz. to 3,000 plants

Celery, 1 oz. to 15,000 plants

Chicory

Clover, Alsike and White Dutch

Clover, Lucerne

Clover, Crimson Trefoil

Clover, Large Red and Medium

Collards, 1 oz. to 5,000 plants

Corn, Rice (Shelled)

Corn, Sweet, $1 / 4$ pint to 100 hills

Cress, $3 / 4 \mathrm{oz}$. to $100 \mathrm{ft}$. of drill. .

Cucumber, $1 \mathrm{oz}$. to 100 hills.

Egg Plant, 1 oz. to 2,000 plants

Endive, 1/4 oz. to $100 \mathrm{ft}$. of drill .

Flax, broadcast

Garlic, Bulbs, 1 ib. to $10 \mathrm{ft}$ of drill

Grass, Blue, Kentucky

Grass, Blue, English

Grass, Hungarian and Millet.

Grass, Mixed Lawn

Grass, Red Top, Fancy, Ċlean

Grass, Red Top, Chaff Seed

Grass Timothy

Wood

\section{Hemp}

Horse-Radish Roots

Kale, 1 oz. to 5,000 plants

Kohl-rabi, $1 / 3 \mathrm{oz}$. to $100 \mathrm{ft}$. of dril

Leek, $1 / 3 \mathrm{oz}$. to $100 \mathrm{ft}$. of drill

Lettuce, $1 / 4 \mathrm{oz}$. to $100 \mathrm{ft}$. of drill.

Martynia, $1 \mathrm{oz}$. to $100 \mathrm{ft}$. of drill.

Melon, Water, 4 oz. to 100 hills

Nasturtium, $2 \mathrm{oz}$. to $100 \mathrm{ft}$. of drill .

Okra, $1 \mathrm{oz}$. to $100 \mathrm{ft}$. of drill.

Onion Seed, $1 / 300$. to $100 \mathrm{ft}$. of drill

Onion Seed, $1 / 3 \mathrm{oz}$.
Onion Seed for sets

Onion Sets, 1 quart to $40 \mathrm{ft}$. of drill

Parsnip, 1/4 oz. to $100 \mathrm{ft}$. of drill

Parsley, $1 / 4 \mathrm{oz}$. to $100 \mathrm{ft}$. of drill..

Peas, Garden, 1 pint to $100 \mathrm{ft}$. of drill

Peas, Field

Pepper, 1 oz. to 1,500 plants

Pumpkin, $1 / 3$ quart to 100 hills

Radish, $2 / 3 \mathrm{oz}$. to $100 \mathrm{ft}$. of drill

Rye

Salsif $y, 3 / \frac{3}{4}$. to $100 \mathrm{ft}$. of drill

Spinach, $1 / 2 \mathrm{oz}$. to $100 \mathrm{ft}$. of drill

Summer Savory

Sunflower

Squash, Summer, $4 \mathrm{oz}$. to 100 hills

Squash, Winter, 8 oz. to 100 hills

Tomato, 1 oz. to 4,500 plants

Tobacco, $1 \mathrm{oz}$. to 5,000 plants

Turnip, $1 \mathrm{oz}$. to $250 \mathrm{ft}$. of drill

Vetches.

Average Time Required for Garden Seeds to Germinate

Days | Days

Bean $\ldots \ldots \ldots \ldots \ldots .5$ to 10 Lettuce........6 to 6 to

Beet......................... 7 to 10 to 10

Cabbage......... 5 to 10 Pea............6 to 10

Carrot................................. to to 18 to 20

Cauliflower.........5 to 10 Pepper...............9 to 14

Celery...................... 10 to 20 to

Corn........... 5 to 8 Salsify............ 7 to 12

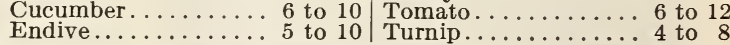

Time Required for Maturity of Different Garden Crops Reckoned from the Day of Sowing the Seed

Beans, String. .....45 to $65 \mid$ Melon, Musk.....120 to 140

Beans, Shell.......65 to 70 Melon, Water.......120 to 140

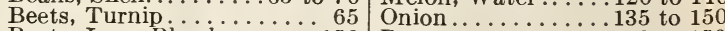

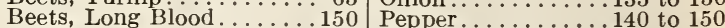

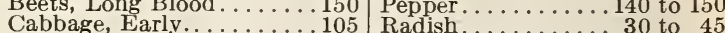

Cabbage, Late...................... 30 to 45

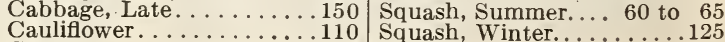

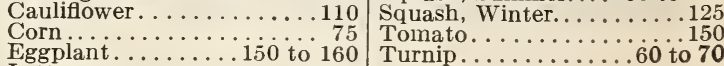

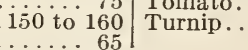




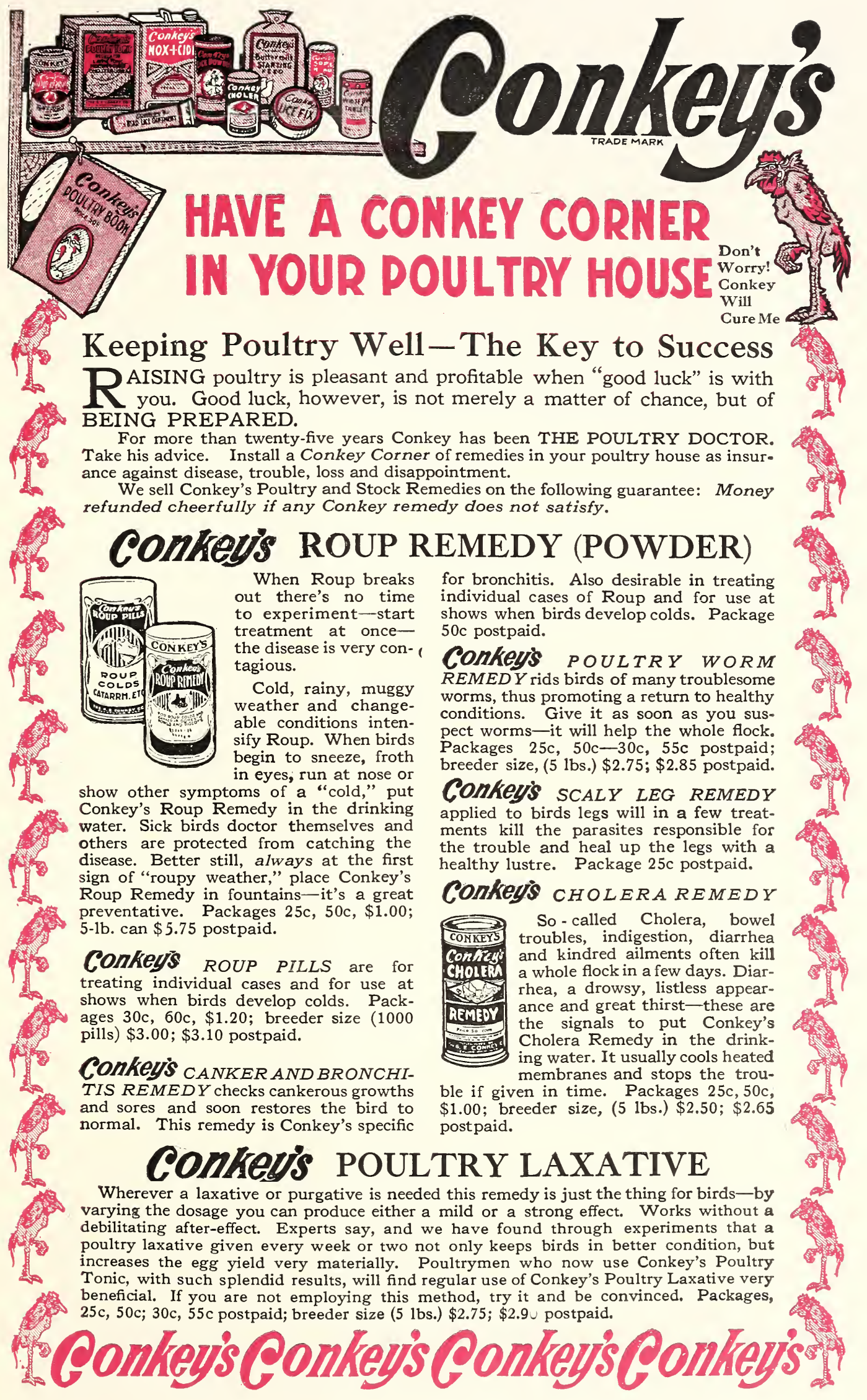




\section{Conkeys Conkeys Conkeys Conkeys Conkey's POULTRY TONIC}

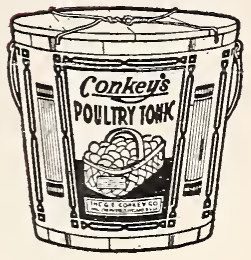

A VERY bird from chick to maturity will be more productive, Dealthier and more profitable if given a good tonic and regulator. Conkey's Poultry Tonic helps birds get more out of their feed. They produce more eggs and better flesh on LESS FEED, by better digestion and assimilation. Don't keep lazy hens eating their heads off when with a little assistance they can become layers instead of loafers.

Conkey's Tonic is all medicine-free from filler, red pepper, and "hot stuff" to overstimulate the birds and break down their health. Conkey's builds on a natural, healthy basis, inducing steady and persistent laying. Keeps the young chicks growing, makes molting easy, strengthens the bird for bad weather and generally maintains a high health average.

Prices - Buy it by the pail. Packages, 25c, 50c, $\$ 1.00$; pails, 12-1b. $\$ 1.60$; 25-1b. $\$ 3.00$; bags, $50-1 \mathrm{~b}$. $\$ 5.00 ; 100 \mathrm{lb}$. $\$ 9.50$. Parcel post, express or freight charges extra.

\section{CORKEy's LICE PREPARATIONS}

COnkeys LICE POWDER is for dusting hens, nests, growing chicks and for use wherever body lice must be overcome. Packages, $10 \mathrm{c}, 25 \mathrm{c}, 50 \mathrm{c}$; pails, 12-1b. $\$ 1.40$; 25-1b. \$2.75. Parcel post, express or freight, extra.

COMkEy LICE LIQUID is for painting roosts, fittings, the inside of house, nest boxes and wherever mites congregate. Cans-qt. 60c; 2 qt. 90c; gal. $\$ 1.50 ; 5$ gal. $\$ 7.00$. Parcel post, express or freight, extra.

\section{COnkEYS SORE HEAD (CHICK-} ENPOX) REMEDY-Don't let this disgusting and highly contagious disease get a start. Many a fine bird has been permanently ruined by neglect. Little brown or black warty spots appear on comb, face and wattles. Under these warts is a pocket of virulent pus. Conkey's Sore Head Remedy attacks the trouble from two angles-a powder for the blood and a salve for rubbing on affected parts. Both treatments in package -for one price. This remedy is used for pigeon pox, Pian, warts and similar afflictions. Packages 25c, 50c; 30c, $55 \mathrm{c}$ postpaid; breeder size $(1 \mathrm{lb}$. salve, $5 \mathrm{lbs}$. powder) $\$ 3.50$; (10 lb. powder only) $\$ 3.50$; $\$ 3.65$ postpaid.

\section{COnkeys BLACKHEAD REMEDY}

- Turkey breeders should have a package ready for instant use, for Blackhead is very hard to cure in an advanced stage. When used soon enough, Conkey's Blackhead Remedy is ordinarily effective. Package 50c; 55 c postpaid.

COAKEYS POULTRY CONDITION$E R$-Highly concentrated fowl regulator, blood purifier and nerve food, to build up birds in rundown condition or for fowls recovering from disease. Splendid for putting birds in condition for shows and sustaining them during exhibition. Package 25c, 50c; 30c, 55c postpaid.

COIfEIS: LIMBERNECK REMEDY (Ptomaine Poisoning) should be kept

\section{Conkeys HEAD LICE OINT.} $M E N T$ is for overcoming and preventing the murderous head louse which "eats up" baby chicks. Packages 10c, 25c.

COnfegs LICE FIX is a preparation in ointment form, for fighting body lice. This method is advocated by some authorities as preferable to powder. One application lasts a month. Packages $25 c, 50 c$.

on hand as Limberneck is an ailment which must be treated promptly. Conkey's seldom fails to give relief if used in time. Packages 50c; $55 \mathrm{c}$ postpaid.

\section{Stock Specialties}

Carkegs FLY KNOCKER - Few preparations have the reputation of this wonderful fly repellent. It is a "fly chaser" that does all claimed for it. Dairymen, drivers, horsemen, stock raisers, cattlemen, sheep raisers declare this remedy the best investment they make -animals free from insects do better in milk and butter fat production, while growing stock unquestionably fattens faster when relieved from biting, stinging, disease-spreading insects. Qt. 60c; 1/2 gal. $90 \mathrm{c}$; gal. $\$ 1.50 ; 5$ gal. $\$ 7.25 ; 10$ gal. $\$ 14.00$. Parcel post, express or freight, extra.

Conkeys COW SPECIAL - Used as a tonic to build up cows in run-down condition and as an aid to food assimilation. Packages 50c, $\$ 1.00$.

Conkeys STOCK TONIC-A general conditioner of real merit for live stock. Not a food but a medicine - all pure medicine, without any filler. Mix it with regular feed. This makes your own stock food at home. Packages, 25c, 50c; pails, 12 lb. $\$ 2.10 ; 25$ lb., $\$ 3.45$; bags, 50 lb., $\$ 4.75$; 100 lb. $\$ 9.00$. Parcel post, express or freight charges extra. 


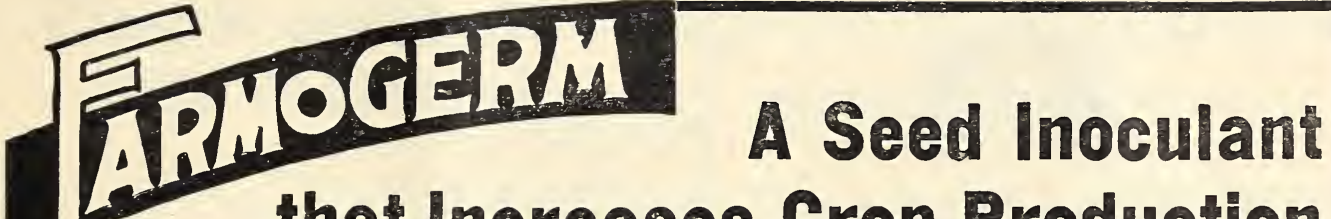 that Increases Crop Production}

Seeds of all legumes-beans, peas, clover, alfalfa, and related crops-will yield far better if inoculated with Farmogerm, and in addition leave in the soil a heavy deposit of nitrogen which benefits all succeeding crops. Farmers and gardeners who have used Farmogerm would not be without it.

Farmogerm Stays Good Indefinitely

Farmogerm keeps for years. Because of the method of sealing the bottle-a patented stopper which admits filtered air and keeps out all impurities-Farmogerm is just as good in five years as when first bottled. Other inoculants get weaker each day-Farmogerm always has its full strength. Just add water and shake the bottle and sprinkle over the seeds as directed. Your crop will benefit beyond your expectations.

\section{Farmogerm Is Economical}

No other inoculant on the market is so strong and virile; no other inoculant will thoroughly treat as much seed. The one-acre size bottle of Farmogerm is sufficient for 20 pounds of clover, 25 pounds of alfalfa, 90 pounds of Canada Field Peas, 50 pounds of Vetch, etc. A different bacteria is required for each crop. When ordering, be sure to state what crops you wish to inoculate.

\section{FARMOGERM PRICES REDUCED}

New scientific methods of production have given lower prices. You cannot now afford to do without Farmogerm.

A special composite culture is prepared for peas, beans and sweet peas-1/4-acre size only. You'll get more peas and beans, and larger sweet peas by using this. Ask for No. 5 , price 50 cts.

Farmogerm prices are: 1 -acre size, $\$ 1 ; 3$-acre size, $\$ 2.50 ; 12$-acre size, $\$ 9$. Full directions accompany each bottle.

\section{STIM- Smplant \\ An All-the-Year Fertilizer for Garden and House Plants}

Stim-U-planT is the most effective concentrated fertilizer manufactured. It can be used easily and profitably on flowers, shrubs, vegetables, fruit and ornamental trees, and will promote more rapid growth and earlier maturity than any other grade of fertilizer. The guaranteed chemical analysis shows $11 \%$ nitrogen, $12 \%$ phosphoric acid, $15 \%$ potash.

\section{Convenient to Use}

Stim-U-plan' comes to you in the form of small tablets, wrapped in waxed paper. A hundred can be put in a drinking-cup, yet they are so highly concentrated that each tablet contains enough food to feed a large plant from ten days to two weeks.

\section{Absolutely Odorless}

Stim-U-plan'T tablets are pleasant to handle; there is absolutely no odor nor other unpleasant feature about them. They may be used on house plants of all kinds-palms, ferns, bulbs, fuchsias, geraniums, and other indoor bloomers.

\section{Stim-U-plant Tablets}

can be used in tablet form, or dissolved in water at the rate of one tablet to the quart, or four to the gallon, which makes a liquid fertilizer of just the right strength. Order Stim-U-plan'T tablets with your seed and plant order. Price, 10 tablets for 15 cts., 30 for 25 cts., 100 for 75 cts., 1,000 for $\$ 3.50$.

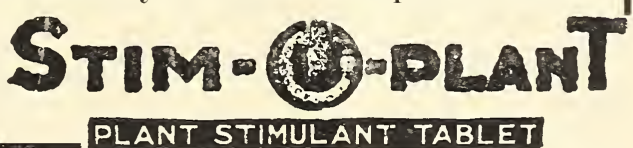

PLANT STIMULANT TABLET

FARMOGERM No. 5 is put up specially for beans, garden peas and sweet peas. 1/4-acre size, 50 cts. 


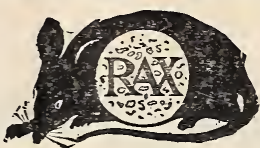

\section{SAVES MONEY BY SAVING CROPS}

It is estimated that rats and mice consume grain each year in the United States alone to the value of more than $\$ 10,000,000$. Most of this waste can be saved if $\mathbf{R a x}$ is given a chance.

\section{Rax Is Not a Poison}

While it is absolutely deadly to rats and mice, it is harmless to human beings, domestic animals, poultry, and birds. It may be used anywhere with complete safety.

\section{Rats Leave Before They Die}

Within a few days after eating food prepared with Rax, rats and mice become feverish and seek the open air. Thus they never die indoors -always outside.

\section{How to Use Rax}

Add water to the bottle and shake contents until water is cloudy. Then moisten bait (bread, crackers or cheese) with the mixture and place it near the holes. $\mathbf{R a x}$ does not affect the taste of the bait.

Directions are furnished with each package. One bottle is enough for an ordinary house; allow one bottle to each 500 feet of floor space in large barns, mills, etc. Price, 75 cts. per bottle, postpaid.

\section{How to Expel Flies and Mosquitos}

Open a door or window and spray PREVENTOL in your dining-room and kitchen to expel flies. Spray it in the nursery to keep them away from your baby. Spray the screens and woodwork about doors and windows. Spray well-PREVENTOL does not stain. Use it daily throughout your home.

Flies breed in filth. An effective way to lessen their number is to spray PREVENTOL over garbage and any refuse on your premises, particularly around stables and outhouses. Sprayed, it will kill their eggs.

To free rooms of mosquitos before retiring at night, spray PREVEN'TOL on the walls, floors, furnishings, bedding, windows, doors, etc. It does not stain and may be sprayed freely on the bed. A well-sprayed bedroom will insure a peaceful night's rest.

It kills and prevents moths, roaches, fleas, bed bugs, poultry lice, and mites.

Prices: Combination package, Sprayer and pt. Preventol \$1.25; pt. Sprayer 65 cts.; pt. Preventol 60 cts.; qt. Sprayer \$1; qt. Preventol \$1; 1/2gal. \$1.75; gal. \$3.

\section{Reduce Your Fertilizer Bill}

Insure your alfalfa, clover, vetch, beans, peas, sweet peas and other legume crops by inoculating the seed with FARMOGERM, thereby taking your nitrogen from the air. Legumes not inoculated take the nitrogen necessary for their growth from the soil the same as corn, cotton, grains, etc., thereby robbing the soil of valuable plant food.

Failures to get a good stand of legumes are often due to lack of inoculation. Why take a chance when you can buy FARMOGERM and make sure of putting the right variety of bacteria of the highest nitrogen fixing ability into your soil.

It is simple to apply - seed can be treated in a few moments. Full directions on each bottle.

Unless your soil is very acid or wet, FARMOGERM will:

Increase the yield and quality of your crops, giving quick growth and early maturity.

Increase their food value.

Make legumes grow in new localities where they cannot otherwise be grown successfully.

Supply nitrates to other crops growing with the inoculated crop.

Enrich the soil for future crops, increasing the permanent value of the farm; better crops -better soil-less fertilizer-less labor.

We have received many letters which tell us that where test strips of land were sown with "Farmogermed" seed, they survived the following winter in much better condition than the portions on which uninoculated seed was used. In some localities where most of the alfalfa has been winter-killed, that grown from seed treated with Farmogerm has come through in good condition.

As inoculation with Farmogerm produces better crops under normal conditions, in the same manner it helps vour crops in their struggle for life when low temperature, drought or incessant rainfall operate against them. The cost of Farmogerm is small, yet sometimes this treatment is the cause of the whole difference between crop failure and success.

The U. S. Department of Agriculture says: "It has been amply demonstrated that clover and numerous other legumes supplied with bacteria, obtain from the air, through the agency of these bacteria, all the nitrcgen they require, and that they leave in the soil considerable quantities for succeeding crops. In the United States the average amount deposited in the soil for sixteen states is 122

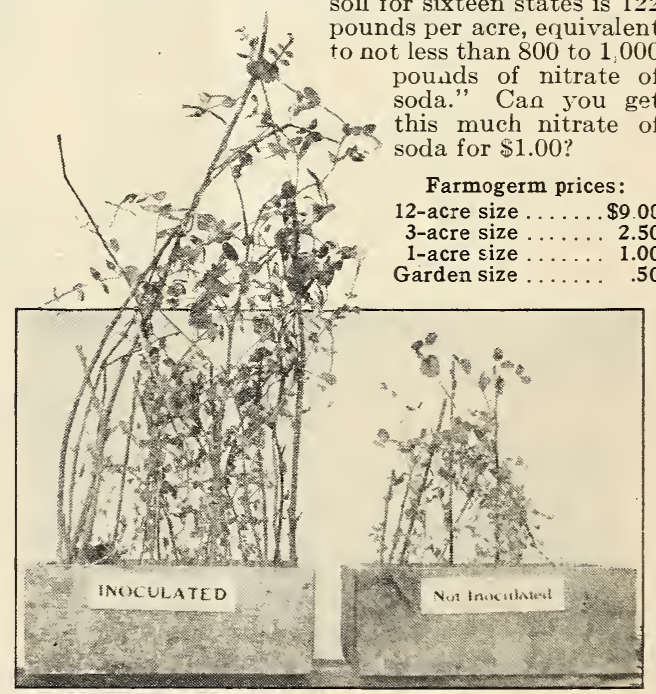

Animal manures are scarce and high in price; FARMOGERM and green manures give the same results, half the cost 


\section{ONION SETS}

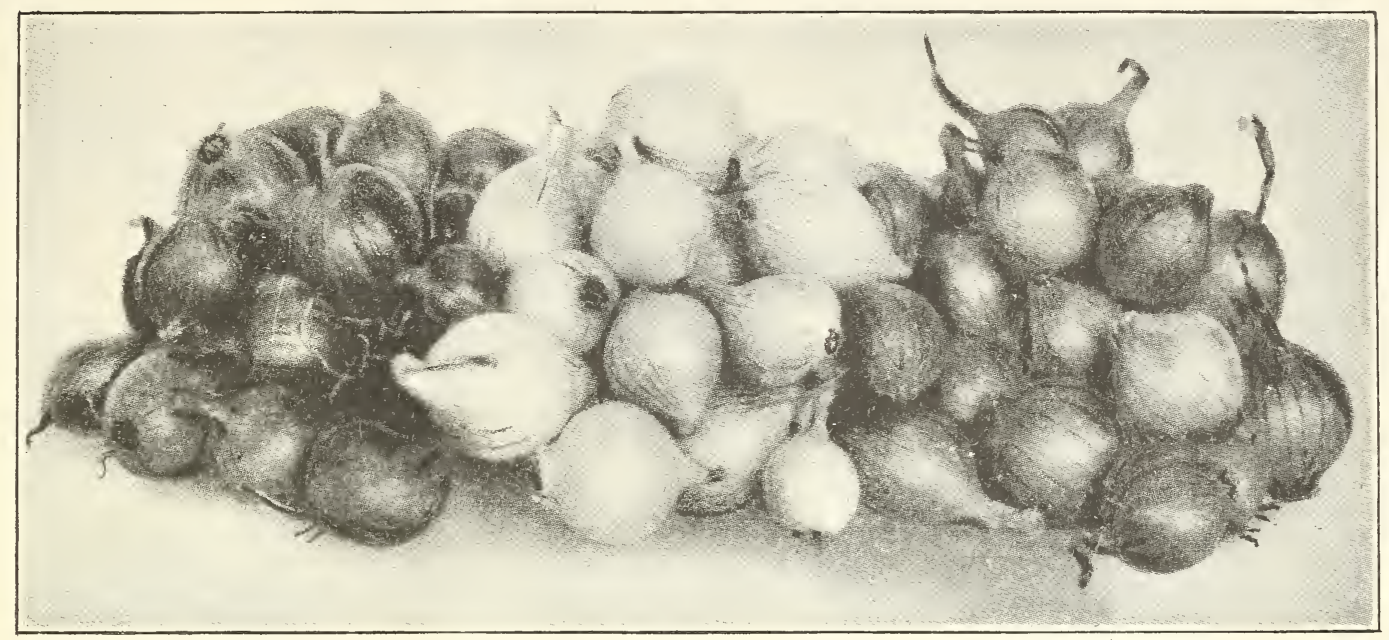

RED

WHITE

YELLOW

Onion Sets. Should be planted as early in the spring as convenient, to obtain early green onions, but they may be set at any time up to June 1st. Set in rows a foot apart and three to four inches between them in the row. Any good soil will suit them. When grown in quantity, high cultivation is given in order to forward the crop for an early market. They are ready for use as soon as the bulbs begin to be of fair size. Those not used in green condition will ripen early in July and make nice Onions. Potato and top onions are grown from bulbs only, growing in clusters. These clusters are separated and the smaller ones kept for seed. There is no crop which pays better than the first load or so of green onions in the market. Onion Sets will make this crop for you. Why not grasp the opportunity offered. Out Sets are carefully grown and choice; they will give the largest returns for the money invested if the product is sold, or excellent green onions for home use at a time when a fresh green vegetable is needed.

The varieties of Onion Sets are:

Yellow Bottom Sets

Red Bottom Sets

White Bottom Sets

Yellow Multipliers

White Multipliers

Potato Onions
Shallots

Winter Top Sets

Genuine Top Sets

\section{PLANT ONION SEED AND ONION SETS Grow More Onions}

\section{Eat More Onions

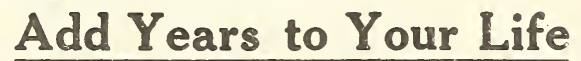

During the recent epidemic of influenza that has swept over the country, some of the doctors and health authorities, particularly in large cities, have been urging their patients to Eat Onions, claiming they are full of live-giving properties and, if eaten frequently, keep the system cleaned out and act as a preventive of disease.

It is claimed that in New York, Chicago and other large cities, Health Inspectors reported that in certain badly crowded sections, where the people were of a nationality addicted to the use of Onions and garlic, there were less colds and influenza than in other localities.

A quart of Onion Sets will plant a 20 -foot row. Several quarts planted as soon as the frost is out of the ground will make green onions to eat much earlier than the seed and if they are not all eaten green, will grow rapidly and can be used later as large oniuns. The right way to do is to plant plenty of Onion Sets early in the Spring and plant a row each week for several weeks and you will have tender, crisp, young green Onions to eat until quite late. You can also plant Onion Seed to make a good crop of Late Keeping Onions for Fall and Winter use.

Onions require rich, loose ground, should be weeded and cultivated frequently and will yield very large crops on good, well-manured ground and are very easy to grow and harvest. Any a mateur gardener should have good success growing Onions and they are also a very profitable crop to raise for the local market or to sell your neighbors, either pulled and bunched early as green Onions or harvested later as large, dry Onions. 


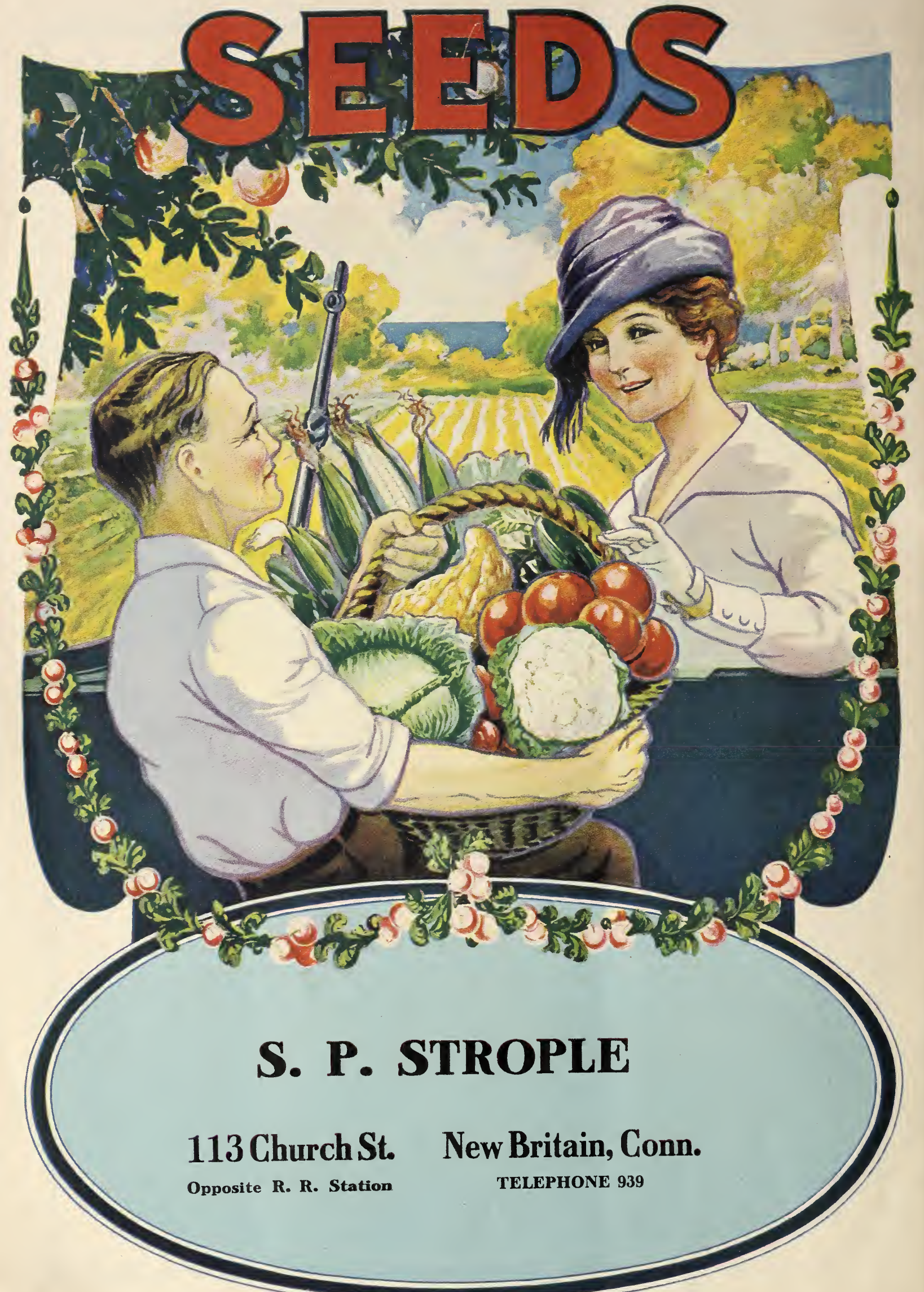

